\title{
EFEITO DA CONCENTRAÇÃO DE N, P, MG, MN E ZN NA MULTIPLICAÇÃO DE LEVEDURAS INDUSTRIAIS
}

\author{
EDVALDO ALBERTO ZAGO \\ Engo-A grônomo - Mestre
}

Orientador: Prof. Dr. HENRIQUE VIANNA DE AMORIM

Tese apresentada à Escola Superior de Agricultura "Luiz de Quei. roz", da Universidade de São Paulo, para obtenção do Título de Doutor em Agronomia - Área de Concentração em Solos e Nutrição de Plantas.

PIRACICABA

Estado de São Paulo - Brasil

- 1982 - 
A minha esposa

MARTA

OFERE\&O

As minhas filhas

JULIANA

e

MARCELE

DEDICO 
Ao "Prof. Dr. Henrique Vianna de Amorim

Ao Prof. Dr. Francisco Krugg

Ao Prof. Dr. Antonio Roque Dechen

A Prof ${ }^{a}$ Dr. Clarice Demetrius

Aos Sr. "Antonio Carlos Travaioli

Antonio Carlos Fernandes

Luiz Lucatt $i$

As Sr.tas sueli Aparecida ố Oliveira

Sandra Cecília Miano

Lourdes Aparecida Dário

A Escola Superior de Agricultura "Luiz de Queiroz", da Uni versidade de São Paulo

Aos Professores do Curso de Pós-Graduação em Solos e Nutrição de Plantas da E. S. A. "Luiz de Queiroz"-USP.

$\bar{A} \quad$ Fermentec S/C Ltda. Assessoria em Fermentação Alcoólica

A Usina Santa Elisa, Usina da Pedra e a Companhia Açucarei ra Vale do Rosário

Ao Departamento de Química da E. S. A. "Luiz de Queiroz" USP.

Ao Setor de Radioquímica do Centro de Energia Nuclear na Agricultura (CENA)

Ao Setor de Bioquimica do Departamento de Química da E. S. A. "Luiz de Queiroz" - USP

Ao Setor de Nutrição Mineral do Departamento de Química da E. S. A. "Luiz de Queiroz" - USP 
iit.

Ao Departamento de Matemática e Estatística da E.S.A. "Luiz de Queiroz" - USP 


\section{I $N$ D I $I C E$}

Pāg.

RESUMO $\ldots \ldots \ldots \ldots \ldots \ldots \ldots \ldots \ldots \ldots \ldots \ldots \ldots \ldots \ldots \ldots \ldots \ldots \ldots \ldots$

vi

SUMMARY $i x$

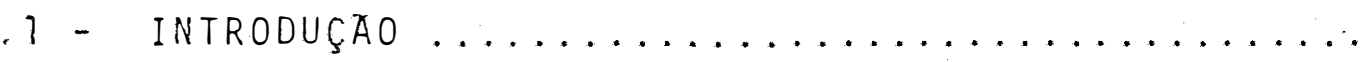

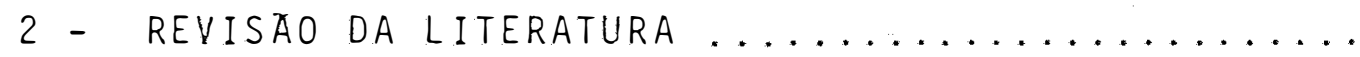

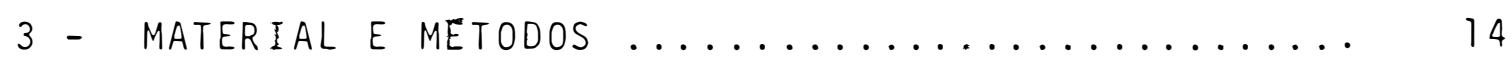

3.1 - Material ................... 14

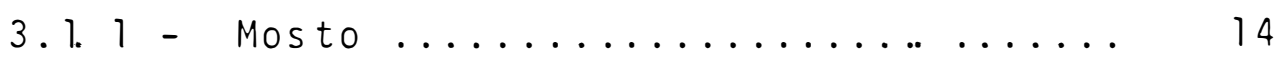

3.1 .2 - Anālises do xarope e do melaço.... 15

3.1.3 - Quantidade de sais nos mostos 2 e $4 \%$ de ART após a diluição do xaro pe e do melaço .............. 15

3.1 .4 - Sais utilizados ............. 16

3.1 .5 - Equipamentos para a condução do

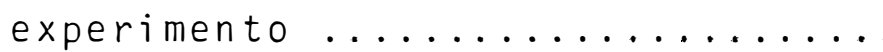

3.1 .6 - Leveduras utilizadas ........... 18

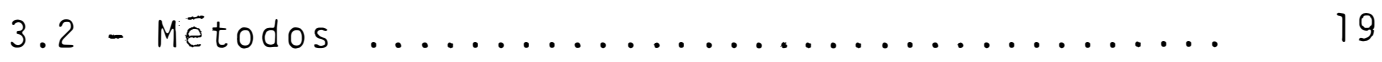

3.2.1 - Determinação de ART no mosto, melaço, xarope e vinho ............

3.2 .2 - Determinação da quantidade de fer

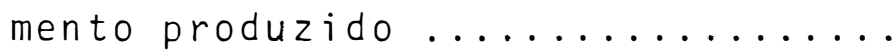


3.2.3 - Determinação da porcentagem de viabilidade e brotamento" das leveduras e carga microbiana ......

3.2.4 - Determinação dos elementos mi-

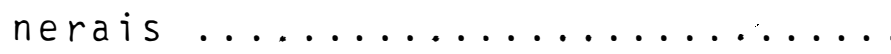

3.2 .5 - Condução dos experimentos ....... 25

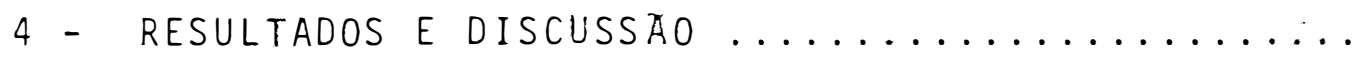

4.1 - Efeito da Suplementação de Vários Elementos em Mosto de Xarope e Melaço na Multiplicação das Leveduras Fleischmann, IZ-1904 e M-300-A após 7 e 22 horas, sob

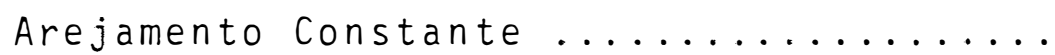

4.2 - Efeito da Suplementação de Nitrogēnio e Fósforo em Diferentes Niveis, em Mosto de Xarope, na Multiplicação das Leveduras Fleischmann, IZ-T904 e M-300-A ....

4.3 - Relação entre Porcentagem de Brotamento e Matéria Seca Produzida ...............

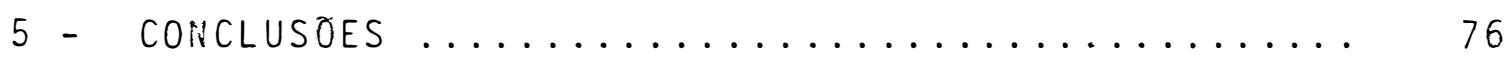

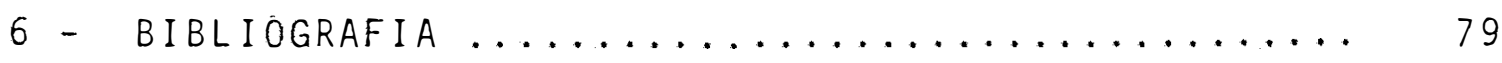

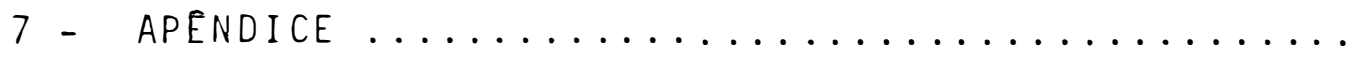




\section{INDICE DE TABELAS}

TABELAS

Pág.

1 Efeito na suplementação de vários elementos em mosto de xarope na multiplicação de levedura Fleischmann, IZ-1904 e M-300-A, após 07 horas

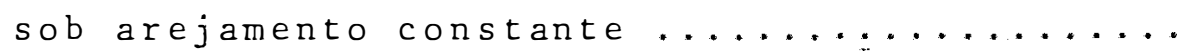

Efeito da suplementação de värios elementos em mosto de xarope na multiplicação de levedura Fleischmann, IZ-1904 e M-300-A, após $2 \dot{2}$ horas

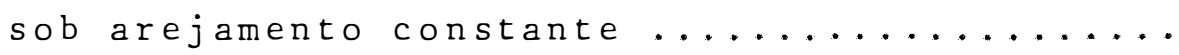

Porcentagem da viabilidade das células Fleisch mann, IZ-1904 e M-300-A, multiplicados em mosto de xarope suplementado com värios elementos

4 Porcentagem de brotamento em células de levedu ras Fleischmann, IZ-1904 e M-300-A, multiplica das em mosto de xarope suplementados com vários

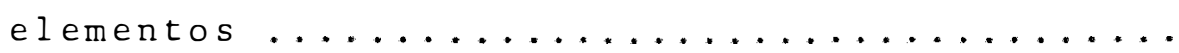

5 Teor de ART no vinho obtido na multiplicação de leveduras Fleischmann, IZ-1904 e M-300-A, em mosto de xarope suplementados com vários elemen tos, após 22 horas sob arejamento constante..

Efeito da suplementação de vários elementos em mosto de melaço na multiplicação das leveduras Fleischmann, IZ-1904 e M-300-A, após 07 horas

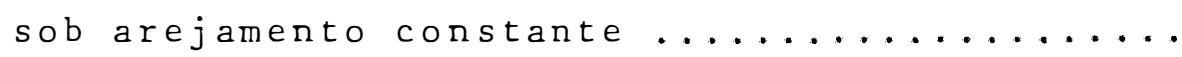

Efeito da suplementação de vários elementos em mosto de melaço na multiplicação das leveduras Fleischmann, IZ-1904 e M-300-A, após 22 horas

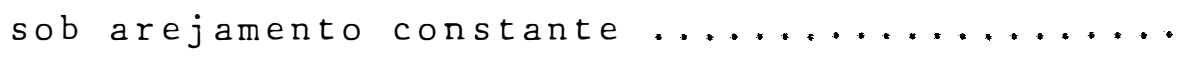


TABELAS

Porcentagem de viabilidade das células Fleisch mann, IZ-1904 e M-300-A multiplicada em mosto de melaço suplementado com vários elementos...

Porcentagem de brotamento em células de levedú ras Fleischmann, IZ-1904 e M-300-A, multiplica da em mosto de melaço suplementado com vários

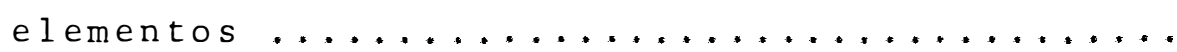

10 Análise mineral da levedura Fleischmann, multi plicada em mosto de xarope suplementado com vā

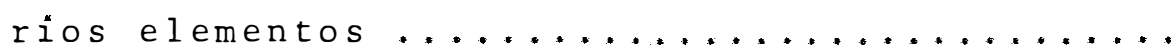

11 Anälise mineral da levedura IZ-1904, multiplicada em mosto de xarope suplementado com vários

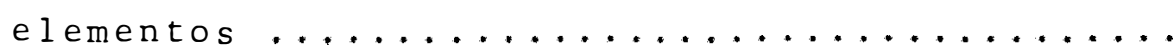

12 Análise mineral da levedura M-300-A multiplica da em mosto de xarope suplementado com vários

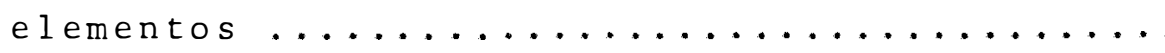

13 Análise mineral da levedura Fleischmann multiplicada em mosto de melaço suplementado com vá

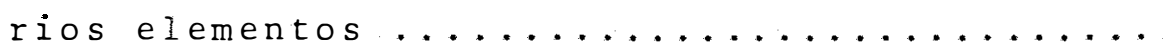

14 Análise mineral da levedura IZ-1904 multiplica da em mosto de melaço suplementado com vários

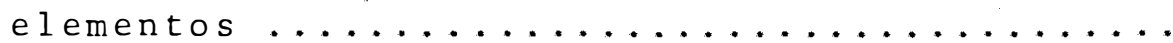

15 Análise mineral da levedura M-300-A multiplica da em mosto de melaço suplementado com vários

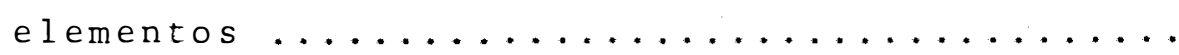


16 Efeito da suplementação de nitrogênio e fósforo em diferentes níveis, em mosto de xarope,na multiplicação da levedura Fleischmanñ, após 07

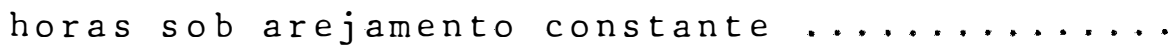

17 Efeito da suplementação de nitrogênio e fósforo em diferentes níveis, em mosto de xarope, na multiplicação da levedura Fleischmann, após 22

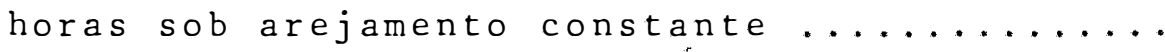

18 Efeito da suplementação de nitrogênio e fósforo em diferentes niveis em mosto de xarope, na multiplicação da levedura IZ-1904, após 07 ho-

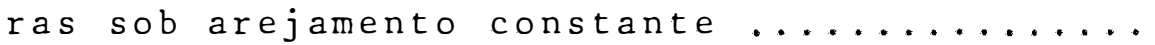

19 Efeito da suplementação de nitrogênio e fósforo em diferentes níveis em mosto de xarope, na multiplicação da levedura IZ-1904, após 22 ho-

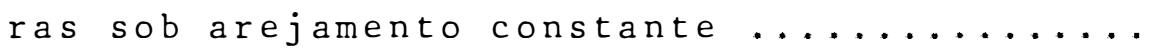

20 Efeito da suplementação de nitrogênio e fósforo em diferentes níveis em mosto de xarope, na multiplicação da levedura M-300-A, após 07 ho-

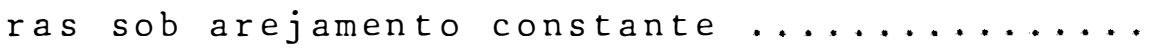

21 Efeito da suplementação de nitrogênio e fósforo em diferentes níveis em mosto de xarope, na multiplicação da levedura M-300-A, após 22 ho-

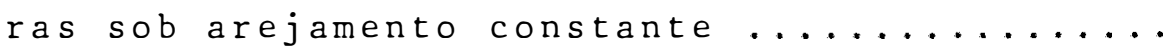

22 Teores de ART no vinho obtido na multiplicação da levedura Fleischmann, em mosto de xarope su plementado com diferentes níveis de nitrogênio e fósforo, após 22 horas sob arejamento cons -

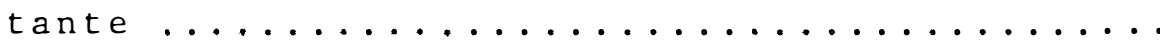


Teor de ART no vinho obtido na multiplicação da levedura IZ-1904, em mosto de xárope supleméntado com diferentes níveis de nitrogênio e fósforo, após 22 horas sob arejamento constante

24 Teor de ART no vinho obtido na multiplicação da levedura M-300-A, em mosto de xarope suplementado com diferentes níveis de nitrogênio e fós foro, após 22 horas sob arejamento constante.

25 Porcentagem de viabilidade das células da leve dura Fleischmann, multiplicadas em mosto de xa rope suplementados com diferentes níveis de ni trogênio e fósforo, após 22 horas sob arejamen

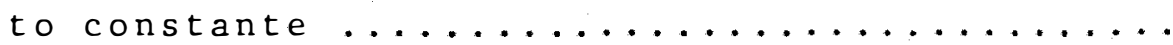

26 Porcentagem de viabilidade das células da leve dura IZ-1904, multiplicadas em mosto de xarope suplementado com diferentes níveis de nitro gênio e fósforo, após 22 horas sob arejamento

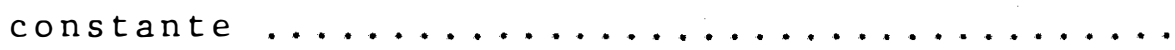

27 Porcentagem de viabilidade das células da leve dura M-300-A, multiplicadas em mosto de xarope suplementado com diferentes níveis de nitrogênio e fósforo, após 22 horas sob arejamento

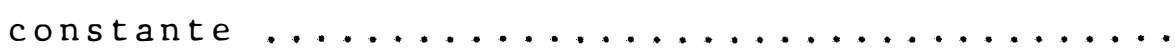

28 Porcentagem de brotamento em células de levedu ra Fleischmann multiplicadas em mosto de xarope suplementado com diferentes niveis de nitro gênio e fósforo, após 22 horas sob arejamento

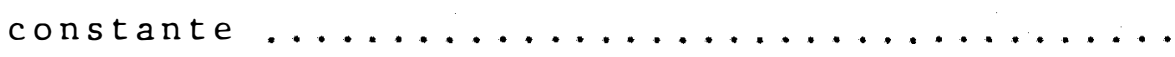


Porcentagem de brotamento em células de levedú ras IZ-1904, multiplicadas em mosto de xarope suplementado com diferentes níveis de nitrogênio e fósforo sob arejamento constante, após

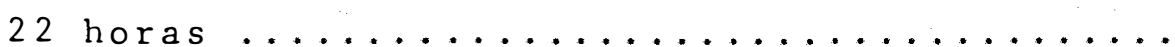

Porcentagem de brotamento em células de levedú ras M-300-A, multiplicada em mosto de xarope suplementado çom diferentes níveis de nitrogênio e fósforo sob arejamento constnate, após

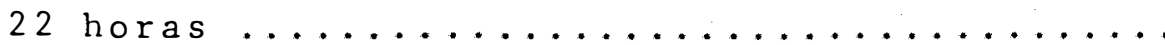

31 Teores de minerais da levedura Fleischmann mul tiplicada em mosto de xarope suplementado com diferentes níveis de nitrogênio e fósforo....

32 Teores de minerais da levedura IZ-1904 multi plicada em mosto de xarope suplementado com di ferentes níveis de nitrogênio e fósforo ......

33 Composição mineral da levedura M-300-A, multiplicada em mosto de xarope suplementado com di ferentes níveis de nitrogênio e fósforo......

34 Relação entre matéria seca e porcentagem de brotamento em levedura Fleischmann .........

35 Relação entre matéria seca e porcentagem de

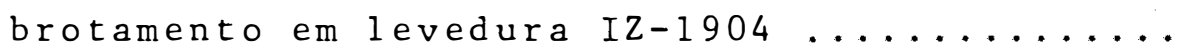

Relação entre matéria seca e porcentagem de brotamento em levedura $\mathrm{M}-300-\mathrm{A} \ldots \ldots \ldots \ldots$ 
$x i$.

TABELAS

Pàg.

37

População bacteriana após a multiplicação das leveduras Fleischmann, IZ-1904 e M-300-A, apös

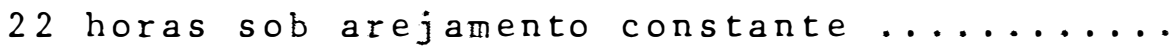




\section{INDICE DE FIGURAS}

FIGURAS

Multiplicação do fermento em escala de laboratório

Efeito da suplementação de vários elementos em mosto de xarope na multiplicação das leveduras Fleischmann, IZ-1904 e M-300-A após 07 e 22 ho ras sob arejamento constante ( $1^{a}$. multiplicação)

Efeito da suplementação de vários elementos em mosto de xarope na multiplicação das leveduras Fleischmann, IZ-1904 e M-300-A após 07 e 22 ho ras sob arejamento constante ( $2^{a}$ multiplicação)

4 Efeito da suplement"ação de värios elementos em mosto de melaço na multiplicação das leveduras Fleischmann, IZ-1904 e M-300-A após 07 e 22 ho ras sob arejamento constante ( $1^{\text {a }}$ multiplicação)

5 Efeito da suplementação de vários elementos em mosto de melaço na multiplicação das leveduras Fleischmann, IZ-1904 e M-300-A após 07 e 22 ho ras sob arejamento constante ( $2^{a}$ multiplicação)

6 Porcentagem de brotamento em células de levedu ras Fleischmann, IZ-1904 e M-300-A multiplicadas em mosto de xarope suplementado com vários elementos após 22 horas, sob arejamento cons -

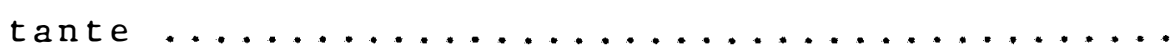

7 Porcentagem de brotamento em células de levedu ras Fleischmann, IZ-1904 e M-300-A multiplicadas em mosto de melaço suplementado com vários elementos após 22 horas, sob arejamento cons-

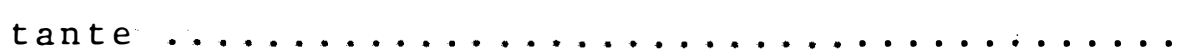


8 Teores de nitrogênio nas leveduras Fleischmann, IZ-1904 e M-300-A multiplicadás em mosto de xa rope suplementado com värios elementos (após 22 horas; material de $1^{a}$. e $2^{\text {a }}$ multiplicação soma-

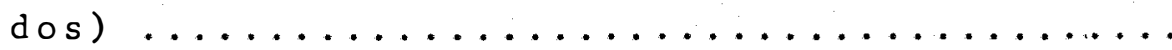

9 Teores de nitrogênio nas leveduras Fleischmann, IZ-1904 e M-300-A multiplicadas em mosto de me laço suplementado com vários elementos (após 22 horas; material de $1^{a}$ e $2^{a}$. multiplicação somados )

10 Teores de potássio nas leveduras Fleischmann, IZ-1904 e M-300-A multiplicadas em mosto de xa rope suplementado com vários elementos (após 22 horas; material de $1^{a}$ e e $2^{a}$ multiplicação soma-

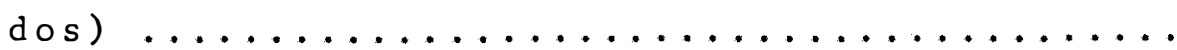

11 Teores de potássio nas leveduras Fleischmann, IZ-1904 e M-300-A multiplicadas em mosto de me laço suplementado com vários elementos (após 22 horas; material de $1^{a}$ e $2^{a}$. multiplicação soma-

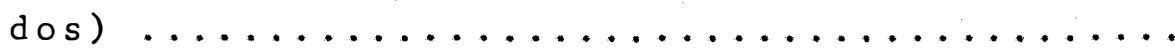

12 Teores de fósforo nas leveduras Fleischmann, IZ-1904 e M-300-A multiplicadas em mosto de xa rope suplementado com vários elementos (após 22 horas; material de $1^{a}$ e $2^{a}$. multiplicação soma-

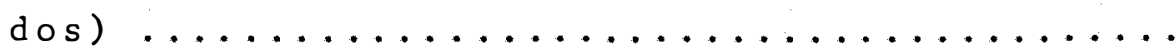

13 Teores de fósforo nas leveduras Fleischmann, IZ-1904 e M-300-A multiplicadas em mosto de me laço suplementado com vários elementos (apös 22 horas; material de $1^{a}$ e 2 ? multiplicação soma-

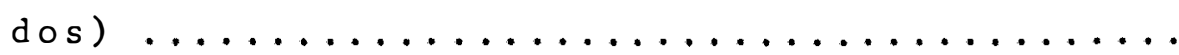


14 Teores de magnésio nas leveduras Fleischmann, IZ-1904 e M-300-A multiplicadas em mosto de xa rope suplementado com vários elementos (após 22 horas; material de $1 \stackrel{a}{\text { a }}$ e $2^{\text {. }}$ multiplicação soma-

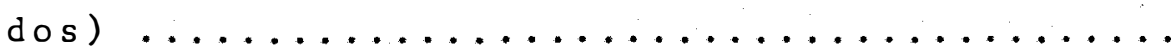

15 Teores de magnésio nas leveduras Fleischmann, IZ-1904 e M-300-A multiplicadas em mosto de me laço suplementado com vários elementos (após 22 horas; material de $1^{a}$ e e $2^{a}$ multiplicação soma-

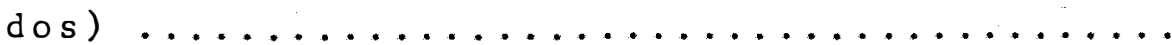

16 Teores de zinco nas leveduras Fleischmann, IZ-1904 e M-300-A multiplicadas em mosto de xa rope suplementado com vários elementos (após 22 horas; material de $1^{a}$ e e $2^{2}$. multiplicação soma-

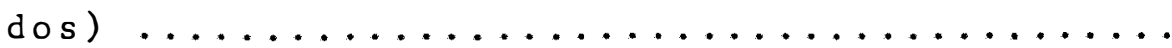

17 Teores de zinco nas leveduras Fleischmann, IZ-1904 e M-300-A multiplicadas em mosto de me laço suplementado com vários elementos (após 22 horas; material de $1^{a}$. e $2^{\text {a }}$ multiplicação somados $\ldots \ldots \ldots \ldots \ldots \ldots \ldots \ldots \ldots \ldots \ldots \ldots \ldots \ldots \ldots \ldots \ldots \ldots \ldots \ldots$

18 Efeito da suplementação de nitrogênio e fósforo em diferentes níveis, em mosto de xarope na multiplicação da levedura Fleischmann, após 07 e 22 horas sob arejamento constante........

19 Efeito da suplementação de nitrogênio e fósforo em diferentes níveis, em mosto de xarope na multiplicação da levedúra IZ-1904, após 07 e 22

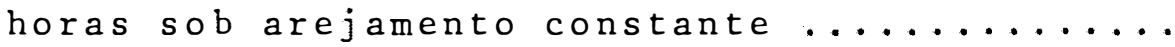


20 Efeito da suplementação de nitrogênio e fósforo em diferentes níveis em mosto de xarope na mul tiplicação da lévedura M-300-A após 07 e 22 ho

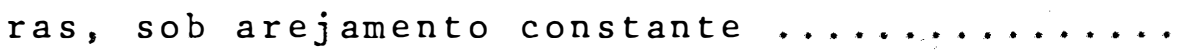

21 Porcentagem de brotamento em cêlulas de levedü ras Fleischmann, IZ-1904 e M-300-A multiplicados em mosto de xarope, suplementado com diferentes níveis de nitrogênio e fósforo, sob are

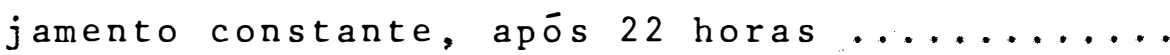

22 Teor de nitrogênio na levedura Fleischmann,muI tiplicada em mosto de xarope suplementado com diferentes níveis de nitrogênio e fósforo....

23 Teor de nitrogênio na levedura IZ-19.04, multi plicada em mosto de xarope suplementado com di ferentes níveis de nitrogênio e fósforo.......

24 Teor de nitrogênio na levedura $M-300-A$, mult plicada em mosto de xarope suplementado com di ferentes níveis de nitrogênio e fósforo......

25 Teor de fósforo na levedura Fleischmann, multiplicadas em mosto ce xarope suplementado com diferentes níveis de nitrogênio e fósforo

26 Teor de fósforo na levedura IZ-1904, multipli cada em mosto de xarope suplementado, com diferentes níveis de nitrogênio e fósforo.....

27 Teor de potássio na levedura IZ-1904, multi plicada em mosto de xarope,suplementado com di ferentes níveis de nitrogênio e fósforo..... 
F IGURAS

28 Teor de potássio na levedura M-300-A, multipli cada em mosto de xarope, suplementado com dife rentes níveis de nitrogênio e fósforo ........

29 Teor de magnésio na levedura Fleischmann, multiplicada em mosto de xarope suplementado, com diferentes níveis de nitrogênio e fósforo ....

30 Teor de magnésio na levedura M-300-A multiplicada em mosto de xarope suplementado com diferentes níveis de nitrogênio e fósforo ........

31 Teor de manganês na levedura IZ-1904, multipli cada em mosto de xarope suplementado com diferentes níveis de nitrogênio e fósforo ........

32 Teor de manganês na levedura M-300-A multiplicada em mosto de xarope, suplementado com diferentes níveis de nitrogênio e fósforo ......

33 Teor de zinco na levedura IZ-1904 multiplicada em mosto de xarope suplementado com diferentes

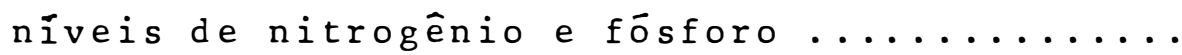

34 Relação entre matéria seca e porcentagem de bro

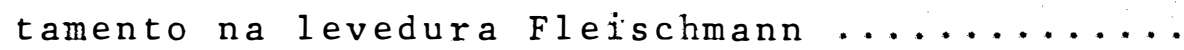

35 Relação entre matéria seca e porcentagem de bro tamento na levedura $\mathrm{M}-300-\mathrm{A} \ldots \ldots \ldots$

36 Relação entre matéria seca e porcentagem de bro

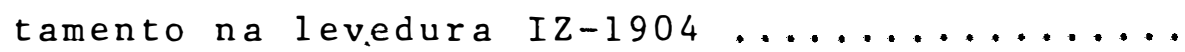


ABREVIATURAS E STMBOLOS USADOS

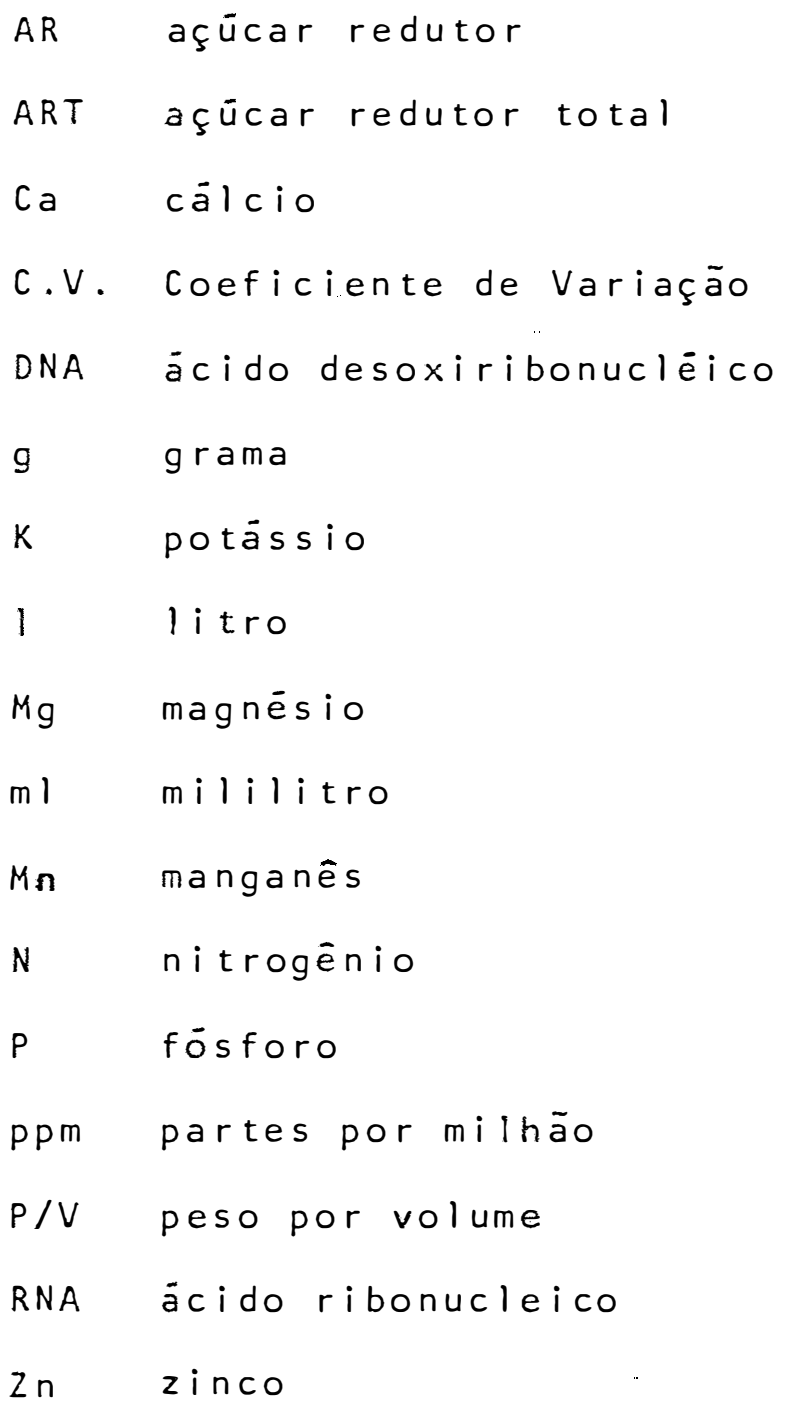




\title{
efeito da concentraç̃o de $N, P$, Mg, Min e Zn NA MULTIPLICACÃO DE LEVEDURAS INDUSTRIAIS
}

\author{
EDVALDO ALBERTO ZAGO
}

\section{HENRIQUE VIANNA DE AMORIM Orientador}

\section{RESUMO}

O presente trabalho teve como objetivo verif car a importância da suplementação dos elementos nitrogênio, fösforo, magnésio, manganès e zinco em mosto de xarope (cal do de cana concentrado) e melaço, bem como os niveis desses elementos, para a multiplicação das leveduras Fleischmann (Saccharomyces cerevisiae), 1z-1204 (saccharomyces uvarum); M-300-A (híbrido das leveduras $12-671$ e $1 z-672$, ambas Saccharomyces cerevisiae).

As leveduras eram inoculados em mostos de xarope e melaço diluídos à 2 e $4 \%$ de açūcar redutor total, com e sem a suplementação dos elementos testados.

A inoculação era feita em $60 \mathrm{ml}$ de mosto $2 \%$. Após três horas em arejamento constante eram adicionados mais $60 \mathrm{ml}$ de mosto $4 \%$ de ART. Após três horas novamente $120 \mathrm{ml}$ de mosto $4 \%$ de ART, eram adicionados e deixava-se arejando 
até se completar 22 horas.

Outro experimento foi feito variando-se as con centrações de nitrogênio e fósforo e o procedimento foi seme Ihante ao acima descrito, apös a inoculação das leveduras.

Foram analisados nos tratamentos em questão os teores de matēria seca das leveduras, porcentagem de brotamen to, viabilidade e anälise dos teores de nitrogénio, fósforo, potässio, magnèsio, manganès e zinco, assim como eram realizadas contagens de bactērias ao microscópio com o objetivo de controlar a infecção.

0 nitrogênio foi o elemento cuja deficiência mais evidenciou o decrēscimo na produção de matēria seca das leve duras Fleischmann, IZ-1904 e M-300-A, tanto em mosto de xa rope quanto no de melaço. As exigências quanto à nitrogênio pelas leveduras foram maiores em mosto de xarope que em mosto. de melaço.

Em mosto de xarope, a maior quantidade de mas sa celular foi obtida quando o mosto era suplementado com 400 ppm de $N$.

0 fösforo tambēm, quando em baixa concentração afetou a produção de matēria seca das leveduras, embora de uma forma menos drástica que o nitrogênio. As leveduras Fleischmann e M-300-A foram as mais exigentes em fósforo que a $12-1904$. 
As concentraçōes médias de magnésio $(0,0167 \%$ em mosto de xarope e 0,051\% em mosto de melaçol, manganes (2,62 ppm em mosto de xarope e 3,67 ppm em mosto de melaço), e zinco $(3,47 \mathrm{ppm}$ em mosto de xarope e 4,8 ppm em mosto de melaçol foram suficientes para a multiplicação, já que as do ses acrescentadas não influenciaram a produção de matéria se ca das très linhagens de levedura. 


\title{
EFFECT OF $N, P, M g$, Min and $Z_{N}$ COnCEntration ON THE GROWTH OF INDUSTRIAL YEASTS
}

\author{
EDVALDO ALBERTO ZAGO
}

HENRI QUE VIANA AMORIM

Adviser

\section{SUMMARY}

The objective of this work was to find out the effect of the addition in the must of syrup (cane juice concentrate) and molasses, of nitrogen, phosphorus, magnesium, manganes, and zinc on the growth of the industrial yeasts (Saccharomyces spp: Fleischmann, IZ-1904 and M-300-A).

The yeast inocula were grown on two and four percent of total sugar of syrup and molasses must, with or without salts addition.

The inocula were introduced into $60 \mathrm{ml}$ of must with $2 \%$ of total sugar. After three hours with constant air bubbling, more $60 \mathrm{ml}$ of must with $4 \%$ total sugar were added. After 3 hours of the second must addition, $120 \mathrm{ml}$ of must with $4 \%$ total sugar were finally added. Air bubbling was kept for 22 hours. 
Following the same procedure, two experiments varying the levels of nitrogen and phosphorus were carried out.

The following determinations were made: yeast dry matter by optical density measurement (colorimetric method) ; budding and viability ( I ight microscopy); nitrogen (Kjeldhal), phosphorus (colorimetric), potassium, magnesium, manganese and zinc (atomic absortion) contents and bacterial counting in all experiments as a matter of control.

Nitrogen was the most important element. The lack of addition of nitrogen salts in the must of syrup and molasses decreased the most the dry matter production in all yeast tested.

The dry matter production was higher in of molasses musts. On the other hand, the addition of 400 ppm of nitrogen in the syrup must was sufficient to archieve the best growth.

The addition of phosphorus also affected the yeast growth, although less drastically than the nitrogen suplementation.

The strains of Fleischmann and $M-300-A$ yeasts were more exacting in phosphorus than the strain 1z-1904. 
The magnesium, manganese and zinc contents existing in the molasses and syrup were sufficient to promote the yeast growth, since there was not significant difference among the treatments with and without addition of thase elements. 


\section{1 - INTRODUCÃO}

As leveduras requerem para o seu desenvolvimento diversos elementos fundamentais, tais como nitrogênio, fós foro, magnésio, potássio e outros em proporções inferiores que são os micronutrientes (HERNANDEZ, 1960).

Além dos fatores nutricionais a taxa de crescimento das células de levedura depende das características da espécie de levedura e dos fatores, tais como pH, temperatura e grau de eficiència da aeração (WHITE, 1954).

No aspecto nutricional, poucos trabalhos tem sido feito no sentido de se determinar as reais necessidades de nutrientes das raças de leveduras usadas nas destilarias bra sileiras, tanto no aspecto de multiplicação quanto no de fer- 
mentação.

No inicio da safra quando as destilarias necessi tam produzir grandes quantidades de massa celular, em tempo relativamente curto, muitas düvidas ainda existem quanto ao uso de nutrientes nessa fase.

o assunto torna-se um pouco mais complexo quando se trata de destilarias anexas ou autōnomas, uma vez que nas primeiras a matéria prima è o melaço que é rico em sais do que o xarope ou caldo de cana, que são as matérias primas utilizadas nas destilarias autōnomas.

Tanto nas destilarias autónomas como nas anexas - tempo que se leva para obter uma quantidade de fermento com pativel com a produção e o volume das dornas, è de um a dois meses. Este atraso na multiplicação provoca prejuízos rele vantes e para diminui-los muitas destilarias compram toneladas de fermento prensado tipo Fleischmann ou I taiquara e adicionam às dornas para se iniciar a safra.

Portanto, o objetivo desse trabalho é estabelecer quais são os elementos minerais mais importantes na mult plicação das leveduras Fleischmann, IZ-1904 e Valusepe Zani tas - $79(M-300-A)$, bem como a sua concentração no meio para se obter uma multiplicação räpida e eficiente, já que os nutrientes minerais estão entre os fatores mais importantes para uma rāpida multiplicação. 


\section{2 - REVISÃO DA LITERATIRA}

Alguns trabalhos já tem sido feito no sentido de se estabelecer os elementos minerais importantes para o crescimento da levedura.

o nitrogênio ë um elemento importantíssimo porque ele entra como constituinte de värias substâncias orgânicas presentes na levedura, tais como, aminoácidos, proteínas, enzimas, purinas e pirimidinas, pigmentos respiratórios (cito cromos), vitaminas, lecitina, cefalina, etc. (WHITE, 1954).

Desta forma, um suprimento de nitrogènio extracelular é essencial para a contínua produção de novas células e a levedura geralmente obtém esse elemento de substáncias re lativamente simples, como sais de amônia, aminoácidos, amidas e nitratos, embora existam evidencias de que dipeptídeos ou mesmo polipeptideos possam ser assimilados (MORRIS, 1958). 
Entre os sais de amônio, o sulfato de amônio tem se mostrado excelente para o crescimento dos diferentes gèneros de levedura.

Segundo WICKERHAM (1946), todas as leveduras são capazes de utilizar sulfato de amônio como fonte de nitrogé nio.

MASSART e HORENS (1952) encontraram um aumento no consumo de oxigènio em levedura crescendo em meio contendo glicose mais sulfato de amónio quando comparada com a crescida em meio contendo só glucose.

Em nossas condiçōes FARAH ALVES e DEL BIANCO (1971) ; VAIRO et aZii (1975) e DOS ANJOS e MAGALHÁES (1980), verificaram haver uma melhora na multiplicação de Saccharomy ces cerevisae obtida de fermento prensado, quando se adicionou sulfato de amónio em mosto de melaço de cana.

SALGADO e SARRUGE (1979) trabalhando com a leve dura saccharomyces uvarum, 1z-1831, encontraram um aumento do teor de proteína na levedura quando foi adicionado sulfato de amônio ao meio.

Tambēm outros sais de amōnio, tais coro o mono, di e triámōnio fosfato, bicarbonato e carbonato de amônio, a cetato de amónio, tartarato de amónio, lactato de amónio e clo reto de amōnio, são utilizados pela levedura com facilidade e bom aproveitamento (SUOMALAINEN e OURA, 1971). 
Quanto ao nitrogēnióna forma de nitrato tem si do usado com cautela em meios de crescimento de leveduras.

Segundo MORRIS (1958) a maioria das espécies com preendendo os gêneros Saccharomyces, Pichia, Hanseniaspora e Debaryomyces, não assimilam nitrato, ao conträrio de todas as espécies de Hansenuza, que conseguem utilizä-lo.

SALGADO e SARRUGE (1979) trabalhando com Saccha romyces uvarum, IZ-1831, encontraram um decréscimo no teor de proteina nas leveduras crescida em meio suplementado com nitrato de sōdio quando a concentração de glucose foi elevada de 1 a 5 ou $10 \%$.

Alèm dos compostos inorgânicos, inümeros são os compostos orgànicos que podem servir como fonte de nitrogénio para as leveduras.

Entre os compostos orgãnicos as leveduras podem obter nitrogénio dos aminoácidos (THORNE, 1933, 1941, 1949; SCHULTZ e POMPER, $1948 ;$ REED e PEPPLER, 1973) , peptideos (MORRIS, 1958), amidas, ácidos nucléicos e seus compostos de rivados (THORNE, 1933 ; DI CARLO et alii, 1951).

Um composto orgânico que tem sido muito utiliza do nas destilarias brasileiras è a uréia.

Segundo DUBOIS. (1975) a levedura possui a enzima ureia amidoliase, que transforma a ureia em alofanato que posteriormente é decomposto em amonia e diōxido de carbono, sendo a amonia retida na forma de glutamato. 
De fato, DOS ANJOS MAGALHAES et a $i$ i (1980) encontraram uma melhoria na produção de proteína em fermento prensado l taiquara quando suplementaram mosto de melaço com ni trogènio na forma de urēia ou sulfato de amóneo.

Quanto as quantidades de nitrogénio usada na for ma de sais inorgānicos, tem-se as seguintes afirmações.

FULMER et alii (1921) trabalhando em meio sintetico encontrou que o cloreto de amōnio, sulfato de amónio; ni trato de amónio e tartarato de amónio quando colocados no meio numa concentração de $0,06 \%(\mathrm{~g} / 100 \mathrm{ml}$ de meio) dão um ótimo de crescimento para a levedura.

FALCONE e ARRUDA (1964) relataram que a suplementação de nitrogênio em nossas indūstrias é feita pela adição de 1 a 1,5 g de fosfato ácido de amónio por litro de mosto.

FULMER (1925) citado por Devereux e Tanner

(1927) encontrou que o ótimo de concentração de $\mathrm{NH}_{4} \mathrm{Cl}$ para o crescimento da levedura foi de $1,88 \mathrm{~g} / 1$ de meio contendo 100 g de sacarose.

DOS ANJOS MAGALHAES et alii (1980) trabalhando com mosto de melaço com $11,6 \%$ de açūcar redutor total, sem arejamento, encontrou que concentrações de nitrogênio na forma de uréia ou sulfato de amónio, superiores a $0,6 \mathrm{~g} / \mathrm{l}$ não é vantagem, quando se leva em conta somente a produção de proteína celular. 
o fösforo tambēm tem sido relatado como um elemento importante para o crescimento das leveduras.

Entre as funçōes que ele desempenha no metabo lismo celular estão a participação nas reações gerais da glicōlise, ação da gliceraldeido-3-fosfato desidrogenase, potencial de redox e oxidações na cadeia respiratōria (LEGGETT, 1961).

STEVENINCK e BOOIS (1964) afirmam existir uma re lação entre polifosfato e entrada de glucose na célula. Segun do STEVENINCK e ROTHSTEIN (1965) ele pode servir como um carregador fosforilado para o transporte ativo da glucose.

NORDHEIN (1969) relata que num meio livre de fös foro, mas com outros nutrientes em níveis normais, a diminuição de fósforo no conteúdo celular ocorre paralelamente com um decrēscimo na respiração.

o fósforo é absorvido pela cēlula de levedura na forma do ànion monovalente $\left(\mathrm{H}_{2} \mathrm{PO}_{4}^{-}\right)$. Se fosfato diäcido de potāssio é usado como fonte de fosfato, consideravelmente mui to mais fosfato pode ser absorvido que quando se usa fosfato monoācido de sōdio. (Rothstein, 1961, citado por SUOMALAl NEN E OURA, 1971).

A um $\mathrm{pH}$ de 4,5 o íon fosfato se encontra totalmente na forma de $\mathrm{H}_{2} \mathrm{PO}_{4}^{-}$, sendo portanto esse pH muito bom pa ra a absorção de fösforo pela levedura (AMORIM, 1977). 
Um aspecto que chama atenção no metabolismo de polifosfato em levedura é a variabilidade no conteúdo do mesmo. Em células deficientes este pode não ser detectado. Por. outro lado, com suprimento de fósforo a levedura pode acumu lar acima de $20 \%$ de seu peso em polifosfato (HAROLD, 1966).

o fosfato pode ser armazenado na forma de polifosfato no vácuolo da célula (INDGE, 1968).

Quanto as quantidades de fósforo usadas na suplementação de meios de crescimento, FALCONE e ARRUDA (1964), relatam que na obtenção do pé de cuba em nossas indūstrias, sa-se de 1 a $1,5 \mathrm{~g}$ de fosfato monoācido de amónio por litro de mosto de melaço, o que corresponde a 234 a 352 ppm de fósforo.

FULMER et alii (1921) trabalhando com meio sintético de crescimento de levedura, verificou que a concentração ótima de fosfato bibásico de potássio foi de $0,02 \%$ o que corresponde a 35,6 ppm de fósforo.

Compostos orgánicos podem ser defosforilados pe la enzima fosfatase situada na parede celular e este grupo fos fato pode ser posteriormente absorvido pela levedura (AMORIM, 1977 ) .

Outro elemento importante para o crescimento das leveduras è o magnésio (FULMer et alii, 1921, 1936 , SUGATA e KOCH, 1226 ; DEVEREUX e TANNER, 1972 ; LESH et alii, 
1938 ; OKOROKOV et aZii, 1975 e LING E HOSENEY, 1977). 0 mag nésio é ativador de várias enzimas e è de particular importân cia na ativação das fosfato - transferases e um nümero grande de descarboxilases (BOWEN, 1966, citado por Suomalain e oura, $1971)$

o magnésio pode sofrer a competição de vários íns presentes no meio. Atribui-se ao cálcio um efeito inibi dor tantó ao crescimento como à fermentação alcoōlica, e este efeito inibidor parece estar ligado à competição entre cälcio e magnésio pelo mesmo sistema de transporte através do plasma lema (AMORIM, 1977$)$.

A competição entre potássio, rubídio, césio e magnésio foi demonstrada por CONWAY e BEARY (1958). Entretan to, quando o magnésio ocorre em grande quantidade no meio externo e o potássio em quantidades normais, o potāssio funciona como transportador de magnèsio (CONWAY e BEARY, 1958).

Quando leveduras eram crescidas em meio contendo quantidades mínimas de potássio e alta taxa de magnésio, o crescimento das leveduras era completamente inibido por $3-4$ días, apōs o que o processo desenvolveu-se lentamente. As cé lulas deficientes em magnēsio ficavam alongadas e formavam lon gas cadeias (CONWAY e BEARY, 1962).

0 pH do meio influencia marcadamente a absorção de potássio e magnésio. Segundo ROTHSTEIN (1954, 1955), cita do por Conway e Beary (1958), na região de pH 3,5 a 4,5, mag 
nésio ë ativamente absorvido na presença de fosfato,e o potās sio não teve nenhum efeito inibitörio.

Quanto à fonte de magnésio e quantidades empregadas, FALCONE e ARRUDA (1964) relataram que a fonte é o sulfato de magnésio e a dosagem adicionada em mosto de melaço é de 0,2 a 0,25 gramas de sulfato de magnēsio pentahidratado por I itro de mosto de melaço, o que corresponde de 22 a 27,5 ppm de magnèsio.

Entre os micronutrientes, zinco tem sido relata do como essencial para o crescimento das leveduras (MC HARGUE e CALFEE, 1931; OLSON e JOHNSON, 1949 ; PECIULIS et alii, 1969 ; PECIULIS, 1973 ; ORTH e BUSHUK, 1973 ; LAWFORD e PIK, $1980 . a ;$ LAWFORD e PIK, 1980.b).

o zinco tem funçōes fisiolögicas importantes, tais como co-fator para numerosas metaloenzimas. Recentemen te foi descoberto que as RNA polimerases são zinco metaloenzi mas (AULD et alii, 1976 ; WANDZILAK e BENSON, 1977). Conse quentemente a deficiēncia de zinco é claramente capaz de afetar o crescimento à nível de transcrição, bem como à nível de metabolismo intermediärio (LAWFORD e PIK, 1980.b).

LAWFORD e PIK (1980.a) observaram que o meio de ficiente em zinco resulta num pronunciado decrēscimo no crescimento da cultura. Eles concluiram que a deficiência de zin co provoca um efeito deletērio no metabolismo energético, embora ainda não seja entendido como ele influi nesse metaboli 
mo .

Segundo PECIULIS et alii (1969) zinco aumentou a quantidade de nitrogénio total em levedura, em considerävel extensão. Tambēm a quantidade de aminoácidos livres na célula é reduzido mais que duas vezes na presença de zinco. A re dução da quantidade de aminoácidos livres e o aumento dos ami noácidos ligados, provam que este elemento estimula a inclu são dos aminoácidos nas proteínas.

Ainda PECIULIS (1973) afirma que o zinco pode ativar fosfatases ácidas e tambēm estimular a biossíntese de riboflavina e àcido föli ico em levedura.

LAWFORD et alii (1980) observaram que a compos ção da levedura Candida utilis NRRL - V-900 com respeito ao conteūdo de RNA e proteina, não foi afetado pela limitação de zinco.

Outro aspecto interessante com respeito ao $\mathbf{z i n -}^{-}$ co è que as leveduras podem acumulà-lo em altas concentrações celulares.

LAWFORD e PIK (1980,a) relataram que células de $C$. utizis podem acumular zinco durante o crescimento e o elevado nível de zinco acumulado não foi inibitōrio ao crescimento.

$$
\text { FEDOROVA et alii (1978) encontrou al to teor de }
$$
zinco em fermento de padaria com alta capacidade fermentativa. 
Quanto às quantidades de zinco adicionadas, Me HARGUE e CALFEE (1931) mostraram que zinco é capaz de estimular o crescimento em concentrações variando de 0,2 a 200 ppm. Entretanto, concentrações de 300 a 500 ppm inibem parcialmente o crescimento.

OLSON e JOHNSON (1949) trabalhando com Saccharo. myces cerevisiae y-30 observaram que elas requerem 1,2 ppm de Zn para o mäximo de crescimento.

POPENKO E BAYAKHUMOV (1971) afirmam que $30 \mathrm{mg}$ de $\mathrm{ZnSO}_{4}$ por litro, aumenta o desenvolvimento de leveduras (Strain $\mathrm{K}_{2}$ e 15$)$.

Além do zinco, outromicronutriente que tem sido mencionado como importante para o crescimento das levedu ras é o manganês (Mc HARGUE e CALFEE, 1931; LIMA, 1953; MOR RIS, 1958 ; PECIULIS et alii, 1969 ; PECIULIS, 1972 ; ORTH e BUSHUK, 1973 )

Entretanto, alguns trabalhos afirmam que o manga nes não teve nenhum efeito no crescimento das leveduras (OLSON E JOHNSON, 1949 ; POPENKO E BAYAKUMOV, 1971 ; LING $\mathrm{CHOSE}$ NEY, 1977 ).

Quanto ao papel fisiolögico desempenhado pelo manganes nas leveduras, poucos são os trabalhos encontrados. Segundo MORRIS (1958) o manganês estä associado com a ativação da arginase. 
A biossintese de tiamina ë fortemente ativada por manganēs (PEC|ULIS, 1973).

PECIULIS et alii (1969) afirmam que o manganês estimula o aumento de proteína, embora em menor grau que molib dènio e zinco.

Quanto a quantidade de manganës a ser emprégada, pequenas concentraçöes promovem o crescimento das leveduras, mas quantidades excessivas são töxicàs. A concentração ötima de manganès è de 10 ppm (Mc HARGUe e CALFEE: 1931).

Também MORRIS, 1958 afirma ser 10 ppm a concentrạ̧a de manganēs que estimula o crescimento da levedura e só se percebe o feito töxico do manganés, quando dosagens acima de 500 ppm são usàdas.

LIMA (1953) em condiçōes de fermentação concluiu que as doses mais aconselhäveis de sulfato de manganès são de 0,01 a $0,08 \mathrm{~g} / \mathcal{L}$, sendo ao redor de $0,01 \mathrm{~g} / \mathcal{L}$ a dose ideal, em trabalho feito com a levedura Saccharomyces cerevisiae Hansen $(1 z-2)$. 


\title{
3 - MATERIAL E MÉTODOS
}

\author{
3.1 - MATERIAL
}

\subsection{1 - Mosto}

Foram utilizados mostos preparados a partir de xarope e melaço provenientes da Usina Santa Elisa S. A., Sertãozinho, SP. Essa matēria prima era diluida até as concentraçōes de 2 e $4 \%(g / 100 \mathrm{ml})$ em ART. Em seguida os sais eram adicionados e o pH acertado à 4,0 com àcido sulfúrico.

O xarope foi obtido através da concentração do caldo de cana. 
3.1 .2 - TEORES DE MINERAIS nO XAROPE E NO MELAGO

\begin{tabular}{lcc}
\hline Elementos & Xarope & Melaço \\
\hline$N(\%)$ & 0,106 & 0,47 \\
$K(\%)$ & 1,37 & 4,58 \\
Ca $(\%)$ & 0,30 & 0,97 \\
Mg $(\%)$ & 0,28 & 0,97 \\
P (ppm) & 305 & 566 \\
Mn (ppm) & 44 & 70 \\
Zn (ppm) & 60 & 90 \\
Brix (volume) & 69,2 & 85,2 \\
Art (\%) & 58,4 & 65,3 \\
\hline
\end{tabular}

Esses resultados são médias de duas repetições.

3.1 .3 - TEORES DE sAIS nOS MOSTOS 2 E $4 \%$ DE ART

3.1.3.1 - Mosto de xarope

\begin{tabular}{lcc}
\hline Elementos & Mosto $2 \%$ & Mosto $4 \%$ \\
\hline$N(\%)$ & 0,0036 & 0,0072 \\
$K(\%)$ & 0,0468 & 0,0937 \\
$C a(\%)$ & 0,0102 & 0,0204 \\
$M g(\%)$ & 0,0095 & 0,0191 \\
$P(p p m)$ & 10,4 & 20,8 \\
$M n(p p m)$ & 1,5 & 3,0 \\
$Z n(p p m)$ & 1,9 & 4,0 \\
\hline
\end{tabular}


3.1 .3 .2 - Mosto de melaço

\begin{tabular}{ccc}
\hline Elementos & Mosto $2 \%$ & Mosto $4 \%$ \\
\hline$N(\%)$ & 0,014 & 0,028 \\
$K(\%)$ & 0,14 & 0,28 \\
$C a(\%)$ & 0,029 & 0,059 \\
$M g(\%)$ & 0,029 & 0,059 \\
$P(p p m)$ & 17,3 & 34,6 \\
$M n(p p m)$ & 2,1 & 4,2 \\
$Z n(p p m)$ & 2,7 & 5,5 \\
\hline
\end{tabular}

\section{1 .2 - SAIS UTILIZADOS}

Foram usados para suplementar os mostos os seguintes sais: fosfato monoácido de amōnio $\left(\mathrm{NH}_{4}\right)_{2} \mathrm{HPO}_{4}$, da Riedel-De Haen A. G. Seelze bei Hannover; sulfato de amónea $\left(\mathrm{NH}_{4} \mathrm{SO}_{4}\right)$, da J. T. Baker Produtos Químicos Ltda, SP ; fosfato monobásico de potássio $\left(\mathrm{KH}_{2} \mathrm{PO}_{4}\right)$ e o sulfato de magnésio $\left(\mathrm{MgSO}_{4}\right)$, ambos da Reagen-Quimibrás Indüstrias Químicas Reunidas, RJ; sulfato de manganès hidratado $\left(\mathrm{MnSO}_{4} \cdot \mathrm{H}_{2} \mathrm{O}\right)$ da QEEL - Química Especializada Erich Loewenberg Ltda, SP ; sulfa to de zinco heptahidratado $\left(\mathrm{ZnSO}_{4} \cdot 7 \mathrm{H}_{2} \mathrm{O}\right)$ da Carlo Erba do Bra sil.

Todos os sais utilizados tinham a especificação puro, pró-anālise. 
Esses sais, antes de serem usados, foram colocados em dessecador à vácuo, com sílica gel, durante uma sema na.

\section{1 .3 - EQUiPAMENTOS PARA A CONDUGAO DO EXPERIMENTO}

A multiplicação das leveduras foi realizada em tubos de ensaio de $45 \mathrm{~mm}$ por $300 \mathrm{~mm}$. O arejamento era fornecido por un compressor de ar $(2,3 \mathrm{ml}$ de ar/ml de mosto/minu to). O ar era esterilizado pela passagem em uma solução de di cromato de potássio à $2 \%$, e depois lavado pela passagem em á gua destilada esterilizada (Figura 1 ).

Os tubos eram mantidos parcialmente imersos em banho maria à $32^{\circ} \mathrm{C}$.

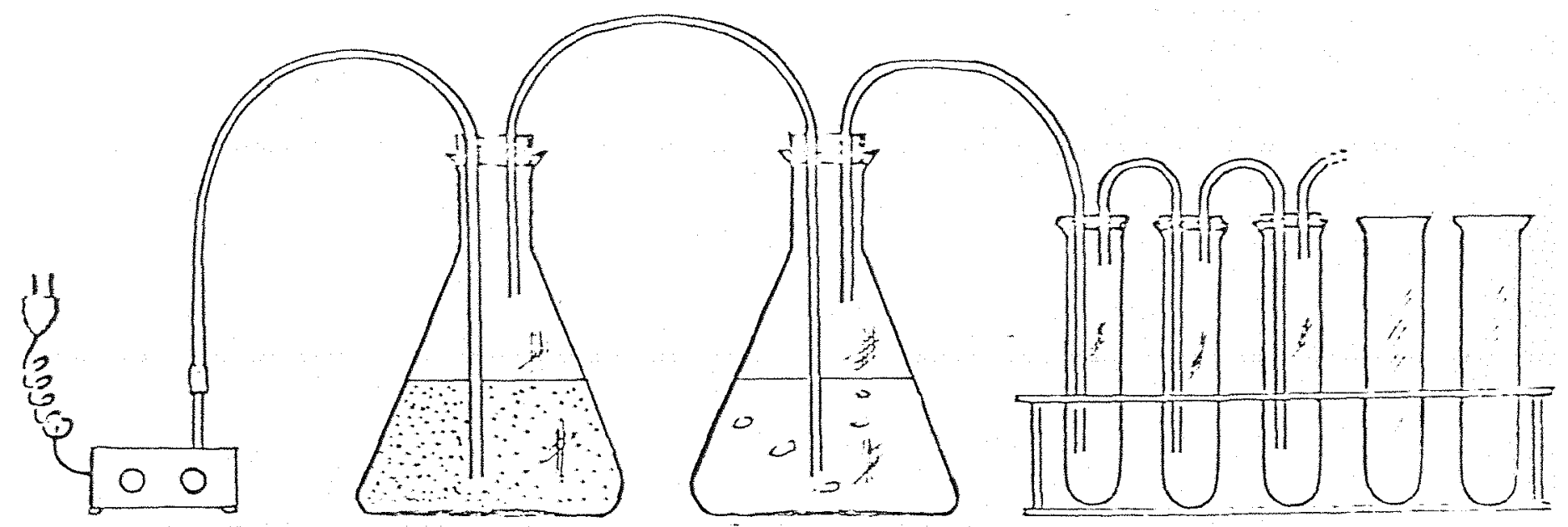

compressor de ar
Solução de Dicroma to de $K$
Agua este-

ri i izada

FIGURA 1 - Multiplicação do fermento em escala de laboratōrio 


\section{1 .4 - Leveduras utilizadas}

Foram utilizadas leveduras que atualmente são as mais empregadas nas destilarias de álcool brasileiras.

A Fleischmann (Saccharomyces cerevisiae) è um fermento de panificação, que acredita-se que seja a mais usada para a fermentação alcoölica no Brasil.

A 1z-1904 (não se tem certeza se è Saccharomyces cerevisae ou Saccharomyces uvarum), foi selecionada no De partamento de Tecnologia da Escola Superior de Agricultura "Luiz de Queiroz" da Universidade de São Paulo, Piracicaba, SP, para tolerar altas temperaturas e as condiçōes das destilarias brasileiras.

A Valusepe Zanitas-79 (M-300-A-Genética) é a primeira levedura hibrida (1z-67) 1 12-672, ambas Sacchoromyces cerevisiael, produzida no Brasil para a produção de älcool. Foi obtida no Departamento de Genética da E.S.A."Luiz de Queiroz", USP, Piracicaba, SP, em 1976, pelo Prof. Dr. Flävio C. A. Tavares. Foi testada em escala de laboratório e industrial pelo grupo do Prof. Dr. Henrique V. Amorim. Na safra de 1980/ 81 esta levedura já produziu cerca de duzentos milhōes de litros de àlcool em trēs destilarias anexas e uma autónoma,e na safra $(1981 / 82)$ a produção atingiu cerca de trezentos milhões de litros de álcool (8\% da produção brasileira). Esta levedu ra foi selecionada para alto teor alcoólico e altas temperatu ras. 
3.2 - MÉTODOS

\subsection{1 - Determinacẽo de art no Mosto, Melaço, XAROPE E VINHO}

A determinaçä́o do ART no mosto, melaço, xarope, e vinho foi feita pelo método de Somogy e Nelson, adaptado por AMORIM et arii (1981).

3.2.1.1 - Determinação de ART no mosto

\subsubsection{1 - Preparo da amostra}

Foram pipetados $2 \mathrm{ml}$ de mosto e diluidos a $200 \mathrm{ml}$ com ägua destilada.

Foram adicionados nesse diluido, 0,2 g de oxala to de södio e agitado. Depois, foram adicionadas 1 g de celi te e agitado durante três minutos.

o conteúdo foi filtrado em papel de filtro, sen do desprezados os primeiros $20-25 \mathrm{ml}$.

Foram pipetados $5 \mathrm{ml}$ desse filtrado e transferido para balào volumétrico de $200 \mathrm{ml}$.

Foram adicionados $10 \mathrm{ml}$ de $\mathrm{HCl} 0,75 \mathrm{~N}$ e o baláo colocado em banho-maria à $65^{\circ} \mathrm{C}$ por 30 minutos. 
Após esfriamento desse material até a temperatü ra ambiente, foram adicionados $10 \mathrm{ml}$ de $\mathrm{NaOH} 0,75 \mathrm{~N}$ e o volume. completado com àgua destilada.

\subsubsection{2 - Reaçāo de Somogy e Nelson}

Foram numerados os tubos de ensaio e adicionados as seguintes soluções:

tubos l e 2: 1 ml de àgua destilada (prova embranco);

tubos 3 e 4 : $1 \mathrm{ml}$ de padrão de açūcar invertido (50 $\mathrm{\mu g}$ de $A R T / m I)$;

outros tubos: I ml dos diluidos conforme obtido no it em 3.2 .1 .1 .1 .

Foi colocado em cada um dos tubos, l ml do reativo de Somogy e agitado.

$0 s$ tubos foram aquecidos durante 15 minutos em ägua fervente.

Após o resfriamento dos mesmos em ägua corrente foi colocado em cada tubo l ml do reativo de Nelson e agitado. A seguir foram colocados em cada tubo $7 \mathrm{ml}$ de água destilada e agitado.

Após 15 minutos de repouso,foi feita a leitura em colorímetro klett - Summerson, usando-se o filtroverde ne $54(540 \mathrm{~nm})$. 


\subsubsection{2 - Determinação de ART no melaço e xarope}

\subsubsection{1 - Preparo da amostra}

Foram pipetados $25 \mathrm{ml}$ dessa solução para balão volumétrico de $250 \mathrm{ml}$ e completado o volume com água destilada. Foram pipetados $25 \mathrm{ml}$ dessa solução e diluídas $250 \mathrm{ml}$ com àgua destilada.

Foram adicionados 0,2 g de celite e agitado e a seguir mais 1 g de celite e agitado durante 3 minutos.

Essa solução foi filtrada em papel de filtro qua litativo sendo desprezados os primeiros $20-25 \mathrm{ml}$.

Foram pipetados $5 \mathrm{ml}$ do filtrado e transferidos para balão volumétrico de $250 \mathrm{ml}$ onde foram adicionados $10 \mathrm{ml}$ de $\mathrm{HCl} 0,75 \mathrm{~N}$ e o balão colocado em banho-maria à $65^{\circ} \mathrm{C}$ durante trinta minutos.

Após esfriar à temperatura ambiente foram adicionados $10 \mathrm{ml}$ de $\mathrm{NaOH} 0,75 \mathrm{~N}$ e o volume completado com ãgua destilada.

\subsubsection{2 - Reação de Somogy e Nelson}

A determinação do ART foi feita conforme o item 3.2 .1 .1 .2$. 
3.2.1.3 - Determinação de ART em vinho

3.2.1.3.1 - Preparo da amostra

Foram pipetados $50 \mathrm{ml}$ de vinho centrifugado e diluido à $500 \mathrm{ml}$ com água destilada. Nesse diluido foram colocados 0,2 g de oxalato de sódio e agitado e a seguir 1,0 g de celite e agitado durante 3 minutos. O conteúdo foi filtrado em papel de filtro qualitativo, sendo desprezados os primeiros $20-25 \mathrm{ml}$.

Foram pipetados $50 \mathrm{ml}$ do filtrado e diluidos a $100 \mathrm{ml}$ com à gua destilada.

3.2.1.3.2 - Reação de Somogy e Nelson

A determinação do ART foi feita conforme o item 3.2 .1 .1 .2 .

3.2 .2 - Determinagão da quantidade de fermento produZIDO

A determinação da quantidade de fermento produzido foi feita pela medida da turbidez da amostra em coloríme tro Klett-Summerson usando filtro vermelho n? $66(660 \mathrm{~nm})$, adaptação do método descrito por PELCZAR et alii (1980). 
Foi feita uma curva padrão para cada l inhágem de levedura, sendo essas leveduras multiplicadas nas mesmas condiçōes do experimento.

\section{2 .3 - Determinasão Da Viabilididade BRotamento DAS LEVEDURAS E INFECGÃO BACTERIANA}

Essas determinaçōes foram feitas segundo COLINS e LYNE (1970), adaptado por AMORIM et alii (1981).

\section{2 .3 .1 - Contagem de bactérias}

Com auxilio de uma alça de platina, foi colocado uma gotícula do corante (azul de metileno e azul de Nilo), no centro de uma esfera que delimita uma ärea de $1 \mathrm{~cm}^{2}$ numa lámina de vidro. Ao lado do corante foram colocados mais 2 goticulas de dispersil. Em seguida foi colocado I ul (microlitrol do material a ser analisado previamente diluido. Com a alça de platina essas substàncias foram convenientemente mis turadas e homogeneizadas e deixadas secar áo ar.

Em seguida, a contagem foi feita ao microscópio com objetiva de imersão $(100 x)$, contando-se 50 campos por lá mina.

A equação usada para o cálculo do nümero de céIulas foi: 


$$
\begin{aligned}
& \text { Nümero de } \\
& \text { células/ml }
\end{aligned}=\begin{gathered}
\text { Fator do } \\
\text { microscópio }
\end{gathered} \times \frac{1 \mathrm{ml}}{\begin{array}{c}
\text { Volume da } \\
\text { amostra }
\end{array}} \times \begin{gathered}
\text { Média do microrganis } \\
\text { mo por campo }
\end{gathered} \times \begin{gathered}
\text { Fator de } \\
\text { diluição }
\end{gathered}
$$

Fator do microscópio: obtido com lâmina micrograduada Fator de diluição: conforme diluição da amostra

\subsubsection{2 - Determinaçāo da porcentagem de viabilidade celular e porcentagem de células em brota- mento}

Foi colocado com auxilio de uma alça de platina 1 gota de corante (azul de metileno + citrato de södio) numa lámina de vidro comum. Ao lado do corante, foi colocado 1 go ta de dispersil. Em seguida, foi colocado na lâmina, $2 \mathrm{ml}$ do material a ser analisado, já convenientemente diluído (diluif̧ão necessäria para dar $40-60$ células por campo). Essas subs tâncias foram homogeneizadas com uma alça de platina e uma la mínula foi colocada de modo a não formar bolhas.

A contagem foi feita em microscópio usando-se objetiva de imersão $(100 x)$.

Apōs a contagem de aproximadamente 1.000 célu la foi calculada a porcentagem de células viàveis e em brotamento.

A porcentagem de cēlulas viāveis foi obtida levando-se em consideração o nümero de células vivas em relação ao total de células observadas.

A porcentagem de células em brotamento foi calculada em relação ao nümero total de células vivas 


\section{2 .4 - Determinacão dos elementos minerais}

o elemento nitrogènio foi analisado pelo método de Kjeldahl, modificado por SARRUGE e HAAG (1974) apös diges tao sulfúrica das amostras.

o fósforo foi analisado segundo CATANI e JACINTO (1974) apōs digestão nitroperclórica das amostras.

os elementos magnésio, potássio, manganès e zinco foram analisados por absorf̧ão atômica, segundo SARRUGE e HAAG (1974), após digestão nitroperclórica das amostras.

\section{2 .5 - CONDUGÃO DOS EXPERIMENTOS}

\section{2 .5 .1 - Esquema geral}

\subsubsection{1 - Preparo do inóculo}

o inóculo da levedura era preparado pela multi plicação em mosto de melaço diluído à 2 e $4 \%$. Em seguida era suplementado com 300 ppm de nitrogènio e 332 ppm de fósforo na forma de fosfato monoácido de amónio, 50 ppm de magnésio na forma de sulfato de magnésio, 10 ppm de zinco na forma de sul fato de zinco pentahidratado e 10 ppm de manganès na forma de sulfato de manganès hidratado.

Após a multiplicação, o levedo era utilizado nos ensaios de multiplicação. O levedo era colocado nos tubos de experimento de modo a se colocar $0,5 \mathrm{ml}$ de fermento (com 8,39\% de umidadel por tubo. 


\subsubsection{2- Multiplicação}

o experimento foi realizado à $32^{\circ} \mathrm{C}$. Após a ino culação, $60 \mathrm{ml}$ de mosto $2 \%$ eram adicionado e a homogeinização era feita. Desses, eram retirados $10 \mathrm{ml}$ para determinação inicial da quantidade de levedura.

Em seguida, o ar era injetado $(2,3 \mathrm{ml}$ de $\mathrm{ar} / \mathrm{ml}$ de mosto por minuto). Apōs trés horas eram adicionados $60 \mathrm{ml}$ de mosto $4 \%$ em ART. Deixava-se arejando mais três horas. Adicionava-se então, mais $120 \mathrm{ml}$ de mosto à $4 \%$ em ART. Depois de uma hora de arejamento eram coletados $10 \mathrm{ml}$ para se fazer a determinação da massa celular produzida. Deixava-se arejan do até se completar 22 horas, quando mais $10 \mathrm{ml}$ eram coleta dos para a determinação da massa de levedura produzida e $\mid \mathrm{ml}$ para a contagem de leveduras viáveis ao microscópio.

Apōs, o material era centrifugado e a levedura era seca em estufa à $85^{\circ} \mathrm{C}$ até peso constante. A levedura seca era triturada em moinho triturador (DANGOUMAU GRINDER DA PRolabo - Paris, França), e o pó analisado quanto ao teor dos elementos, anteriormente discriminados. 
3.2.5.2 - Efeito da suplementação de diversos elementos na multiplicação das leveduras Fleischmann, 1Z-1904 e M-300-A em mosto de xarope

\section{2 .5 .2 .1 - Preparo do mosto}

o xarope era diluído até as concentrações corres pondentes a $2 \%$ (mosto 1 ) e $4 \%$ (mosto 2 ) em ART e os sais eram adicionados de acordo com o seguinte esquema:

a - Testemunha:

Não foram adicionados sais ao mosto.

b - Tratamentos sem suplementação em nitrogênio:

Eram adicionados os seguintes elementos:

332 ppm de $P$ na forma de fosfato monoācido de potássio; $50 \mathrm{ppm}$ de Mg na forma de sulfato de magnésio;

10 ppm de Zn na forma de sulfato de zinco;

10 ppm de Mn na forma de sulfato de manganès.

c - Tratamento sem suplementação em fósforo:

300 ppm de $N$ na forma de sulfato de amônio;

50 ppm de $M g$ na forma de sulfato de magnësio;

$10 \mathrm{ppm}$ de $\mathrm{Zn}$ na forma de sulfato de zinco;

$10 \mathrm{ppm}$ de Mn na forma de sulfato de manganés.

d - Tratamento ser suplementação de magnēsio:

300 ppm de $N$ e 332 ppm de $P$ na forma de fosfato mono-ācido de amónio;

10 ppm de Zn na forma de sulfato de zinco;

10 ppm de Mn na forma de sulfato de manganès.

e - Tratamento sem suplementação de zinco:

300 ppm de $N$ e 332 ppm de P na forma de fosfato mor no-äcido de amônio;

50 ppm de Mg na forma de sulfato de magnésio;

10 ppm de Mn na forma de sulfato de manganès.

f - Tratamento sem suplementação de manganès:

300 ppm de N e 332 ppm de P na forma de fosfato mono-àcido de amōnio; 
$50 \mathrm{ppm}$ de Mg na forma de sulfato de magnésio;

$10 \mathrm{ppm}$ de $2 \mathrm{n}$ na forma de sulfato de zinco.

9 - Tratamento completo:

$300 \mathrm{ppm}$ de $N$ e $332 \mathrm{ppm}$ de $P$ na forma de fosfato mo no-äcido de amônio;

$50 \mathrm{ppm}$ de $\mathrm{Mg}$ na forma de sulfato de magnésio;

$1.0 \mathrm{ppm}$ de $Z$ n na forma de sulfato de zinco;

$10 \mathrm{ppm}$ de Mn na forma de sulfato de manganês.

Após a adição dos sais o pH era acertado a 4,0 e os mostos armazenados em congelador $\left(-15^{\circ} \mathrm{C}\right)$. Uma alíquota de cada tratamento era separada para anälise de ART.

3.2.5.2.2 - Teores de ART dos mostos (\% ART P/V)

\begin{tabular}{lcc}
\hline Tratamentos & Mosto $1 \pm 2 \%)$ & Mosto $2( \pm 4 \%)$ \\
\hline$T$ & 2,2 & 3,8 \\
$-N$ & 2,2 & 3,7 \\
$-P$ & 2,3 & 3,7 \\
$-M g$ & 2,3 & 3,8 \\
$-M n$ & 2,3 & 3,8 \\
$-\mathrm{Zn}$ & 2,1 & 3,8 \\
$C$ & 2,1 & 3,8 \\
\hline
\end{tabular}

3.2.5.2.3 - Conduçāo do experimento

o experimento foi conduzido do mesmo modo des crito no item 3.2.5.1. O inóculo do 2 ? dia de multiplicação 
ra obtido respectivamente de cada tubo da multiplicação ante rior (l? multiplicação)

3.2.5.3 - Efeito da suplementação de diversos elementos na multiplicação das leveduras Fleischmann, IZ-1904 e M-300-A em mosto de melaço (1 : Exp.)

3.2.5.3.1 - Preparo do mosto

0 mosto foi preparado conforme o item 3.2.5.2.1, somente que utilizando melaço em vez de xarope.

3.2.5.3.2 - Análíse do ART dos mostos (\% ART P/V)

\begin{tabular}{ccc}
\hline Tratamentos & Mosto $1( \pm 2 \%)$ & Mosto $2( \pm 4 \%)$ \\
\hline T & 1,7 & 3,6 \\
$-N$ & 1,7 & 3,5 \\
$-P$ & 1,7 & 3,4 \\
$-M g$ & 1,9 & 3,4 \\
$-M n$ & 1,8 & 3,7 \\
$-2 n$ & 1,9 & 3,5 \\
$C$ & 1,9 & 3,8 \\
\hline
\end{tabular}


3.2 .5 .3 .3 - Conduçāo do experimento

0 experimento foi conduzido, do mesmo modo des crito no.item 3.2.5.1.

3.2.5.4 - Efeito da suplementaçāo de nitrogēnio e fósforo em diferentes niveis, em mosto de xarope, na multiplicação das leveduras Fleischmann IZ-1904 e M-300-A (2: experimento)

3.2.5.4.1 - Preparo dos mostos

O xarope era diluido até as concentrações corres pondentes a 2 e $4 \%$ de ART e os sais eram adicionados no seguin te esquema:

a - Todos os mostos eram suplementados com a adifão de:

50 ppm de Mg na forma de sulfato de magnésio;

10 ppm de Zn na forma de sulfato de zinco;

10 ppm de Mn na forma de sulfato de manganès.

b - A adição de fósforo variava de 0,75 e 150 ppm na forma de fosfato monoácido de potássio..

c - A adif̧ão de nitrogènio variava de $0,100,200,300$ e 400 ppm na forma de sulfato de amônio. 
3.2.5.4.2 - Teores de ART dos mostos

\begin{tabular}{|c|c|c|c|c|c|c|c|c|c|c|}
\hline Tratamen & \multicolumn{3}{|c|}{ Fleischmann } & \multicolumn{3}{|c|}{$M-300-A$} & \multicolumn{4}{|c|}{$1 z-1904$} \\
\hline tos $N / P$ & Mosto 1 & Mosto & 2 & Mosto & $1^{\prime}$ Mosto & 2 & Mosto & 1 & Mosto & 2 \\
\hline $0 / 0$ & 1,9 & 3,6 & & 2,6 & 3,0 & & 2,0 & & 3,8 & \\
\hline $100 / 0$ & 1,9 & 3,7 & & 2,5 & 3,0 & & 2,2 & & 3,9 & \\
\hline $200 / 0$ & 1,9 & 3,6 & & 2,6 & 3,0 & & 2,2 & & 3,9 & \\
\hline $300 / 0$ & 1,9 & 3,7 & & 2,7 & 3,5 & & 2,3 & & 3,9 & \\
\hline $400 / 0$ & 1,9 & 3,7 & & 2,7 & 3,1 & & 2,3 & & 3,9 & \\
\hline $0 / 75$ & 1,9 & 3,7 & & 2,5 & 3,1 & & 2,3 & & 4,0 & \\
\hline $100 / 75$ & 1,9 & 3,7 & & 2,6 & 3,1 & & 2,2 & & 4,0 & \\
\hline $200 / 75$ & 1,9 & 3,5 & & 2,7 & 3,1 & & 2,2 & & 3,8 & \\
\hline $300 / 75$ & 1,0 & 3,4 & & 2,7 & 3,1 & & 2,2 & & 3,8 & \\
\hline $400 / 75$ & 1,9 & 3,7 & & 2,7 & 3,1 & & 2,1 & & 3,9 & \\
\hline $0 / 150$ & 1,9 & 3,4 & & 2,6 & 3,2 & & 2,2 & & 3,9 & \\
\hline $100 / 150$ & 1,9 & 3,6 & & 2,6 & 3,1 & & 2,2 & & 4,0 & \\
\hline $200 / 150$ & 1,9 & 3,6 & & 2,7 & 3,1 & & 2,2 & & 3,9 & \\
\hline $300 / 150$ & 1,9 & 3,2 & & 2,8 & 3,1 & & 2,1 & & 3,9 & \\
\hline $400 / 150$ & 1,9 & 3,1 & & 2,8 & 3,1 & & 2,2 & & 3,9 & \\
\hline
\end{tabular}

3.2 .5 .4 .3 - Condução do experimento

o experimento foi conduzido conforme item 3.2 .5 .1 somente sendo modificada a adição dos sais que foi feita confor me o item 3.2.5.4.1. 
4 - RESULTADOS E DISCUSSÃO

4.1 - Efeito da Suplementagāo de VArios Elementos em Mosto de Xarope e Melago na Multiplicagáo das leveduras Fleischmann, IZ-1904 E M-300-A após 7 e 22 HORAs, sob AREjamento Constante

os resultados obtidos encontram-se nas Tabelas em anexo. Para facilidade eles foram colocados na forma de Gráficos que podem ser visualizado nas figuras do texto.

A taxa de conversão de açūcar em matéria seca de levedura foi baixa, (123 mg de matéria seca por grama de a çūcar) quando o ideal seria $500 \mathrm{mg}$ de matéria seca por grama de af̧ūcar (REED e PEPPLER, 1973). Isso se deve ao fato de não se possuir aparelhagem adequada para se manter as condiçōes I deais para a multiplicação, isto é, de se manter um suprimento continuo de mosto de forma a manter baixas concentraçōes de açücar no meio. 
A população bacteriana no final das multiplica f̧ões encontra-se na Tabela 37. Por esses resultados pode-se constatar que as multiplicações foram feitas em um nivel de bactēria da ordem de $10^{6}$ bactérias/ml.

0. nitrogènio foi o elemento, cuja deficiència mais evidenciou o decréscimo na produção de matéria seca das levedu ras, tanto em mosto de xarope quanto de melaço, conforme pode ser observado nas figuras $2,3,4$ e 5 (correspondente às Tabelas $1,2,6$ e 7) e também pelo teor de açücar residual no vinho (Tabela 5).

Em mosto de melaço a levedura que se mostrou mais exigente em nitrogēnio foi a Fleischmann, seguida pela M-300-A e depois a $12-1904$. Os resultados evidenciaram também que quanto mais exigente em nitrogēnio, maior será a produção de matéria seca produzida pela levedura quando em solução com pleta.

o efeito causado pela falta de nitrogènio foi mais drástico no segundo dia de multiplicação o que parece evidenciar uma alteração no metabolismo nitrogenado das levedu ras jā que o inóculo do segundo dia foi obtido com o material deficiente da primeira multiplicação (Figuras 3 e 5 , correspondentes as Tabelas $1,2,6$ e 7 ). 

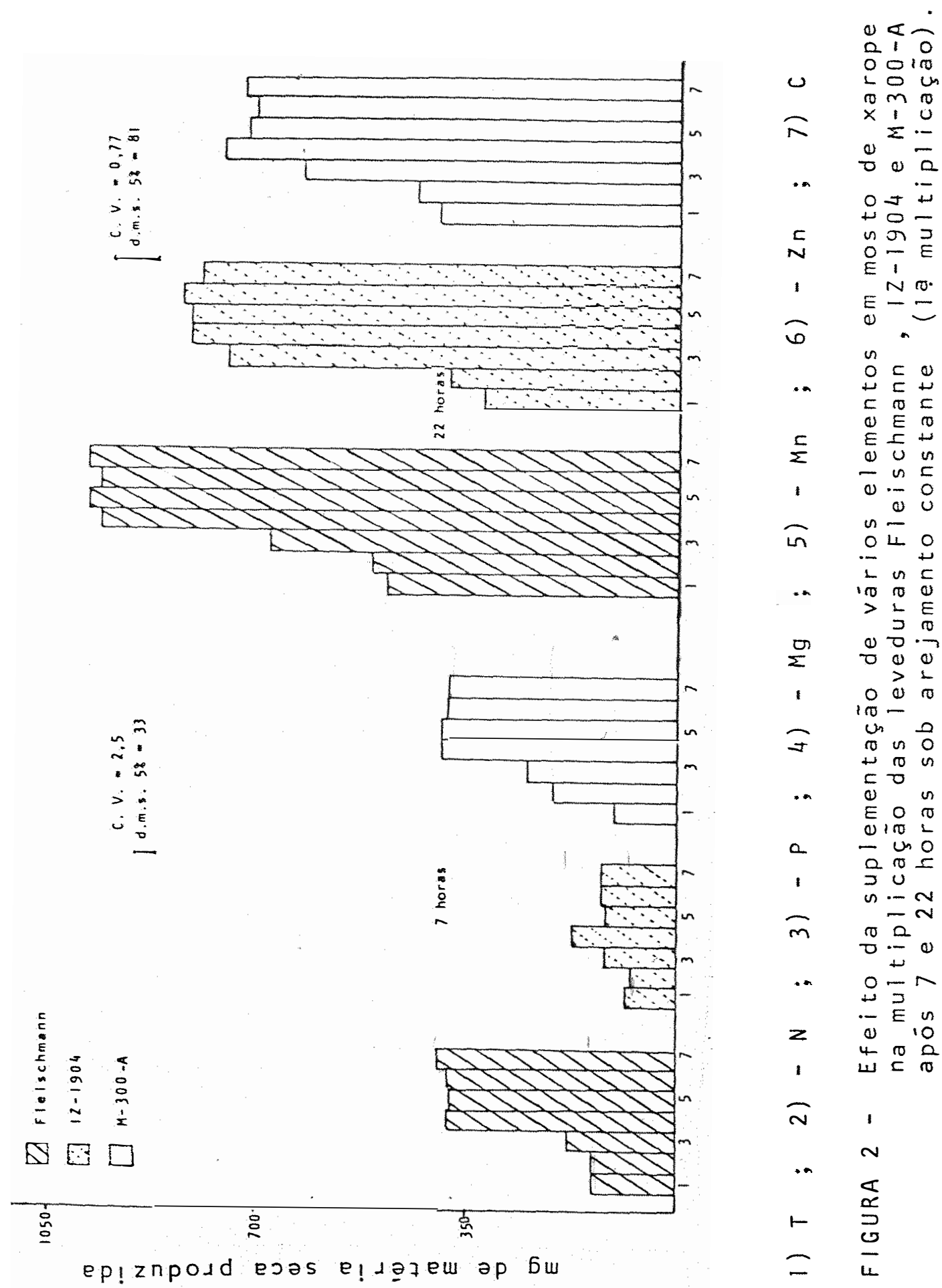


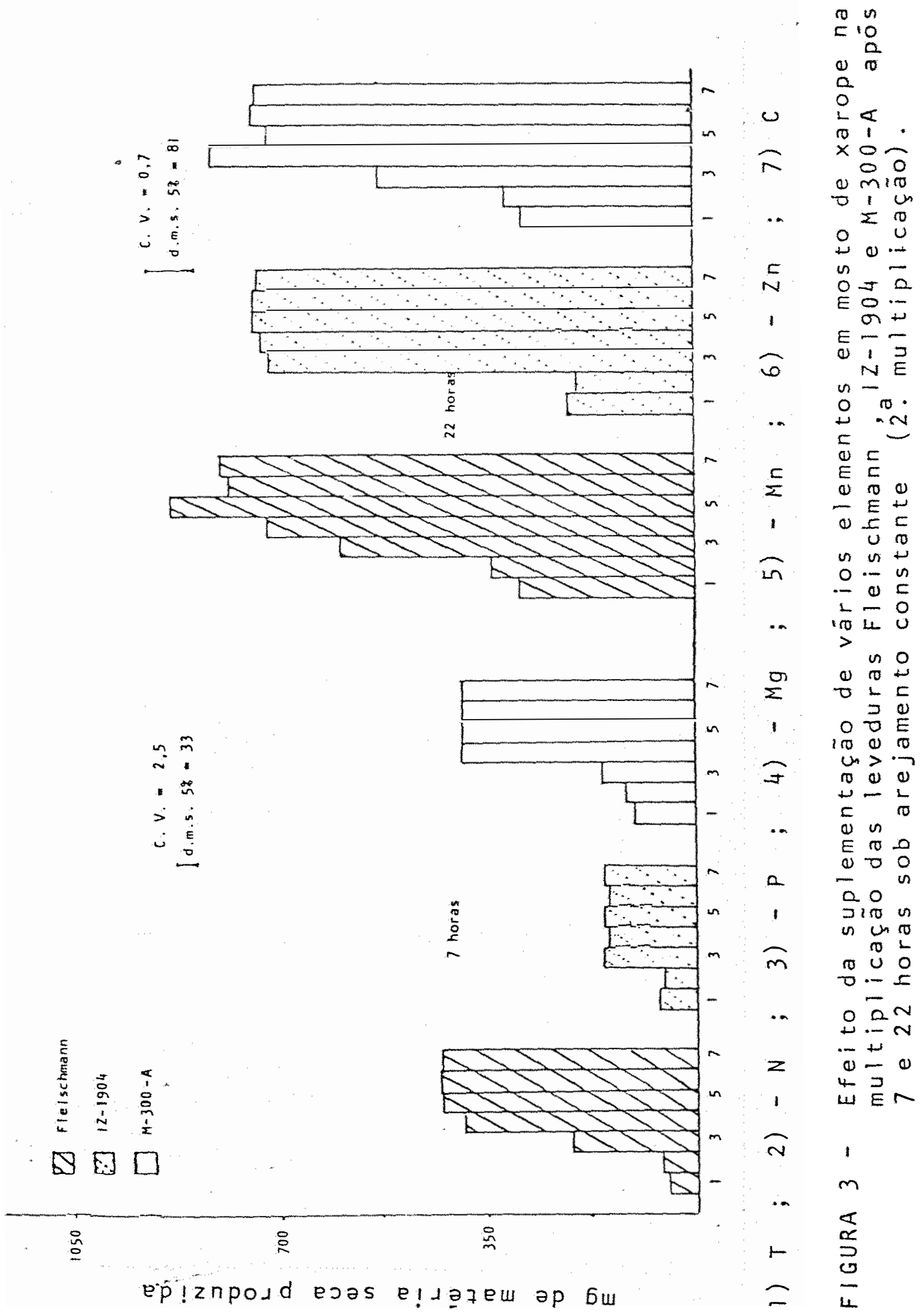



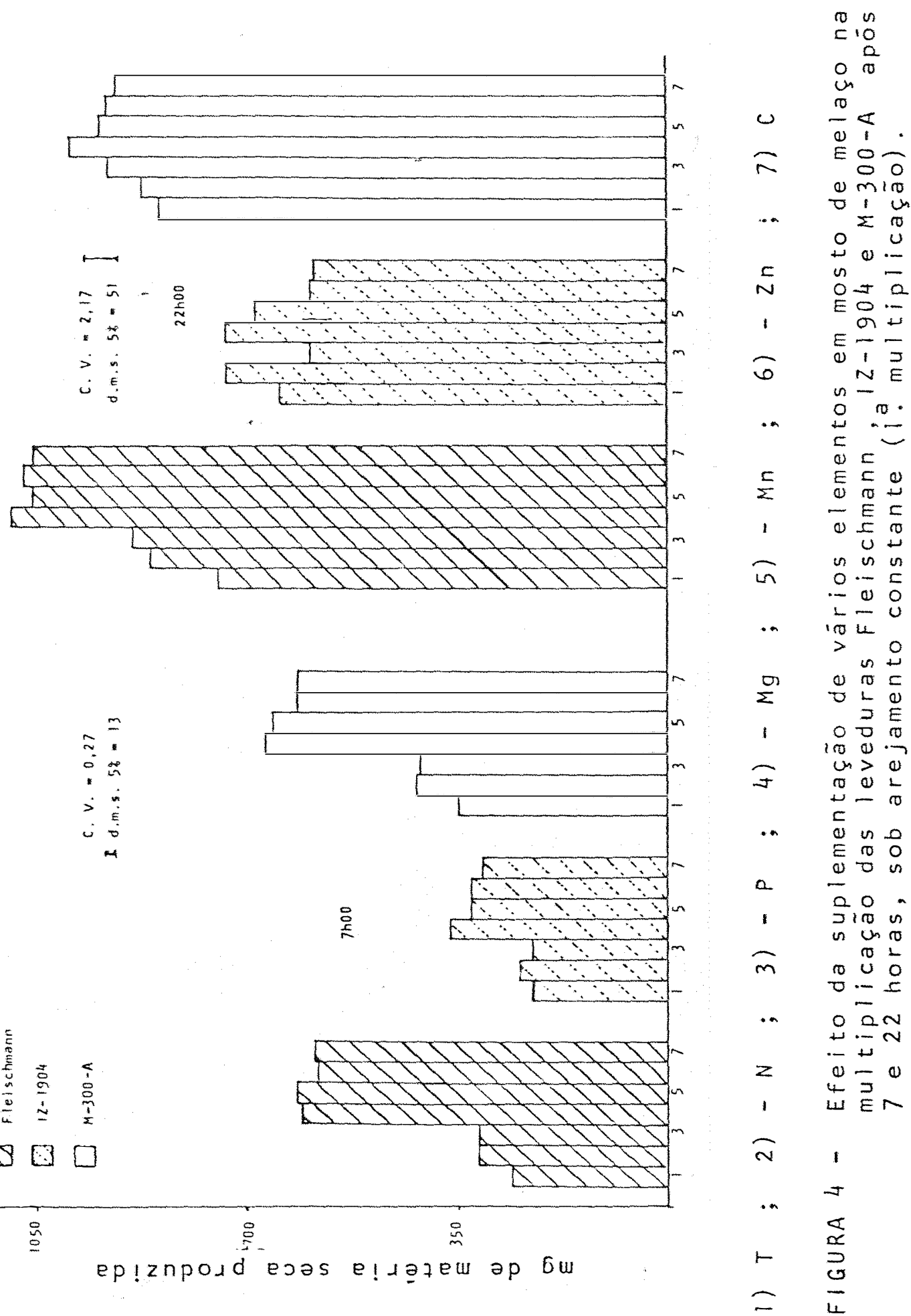


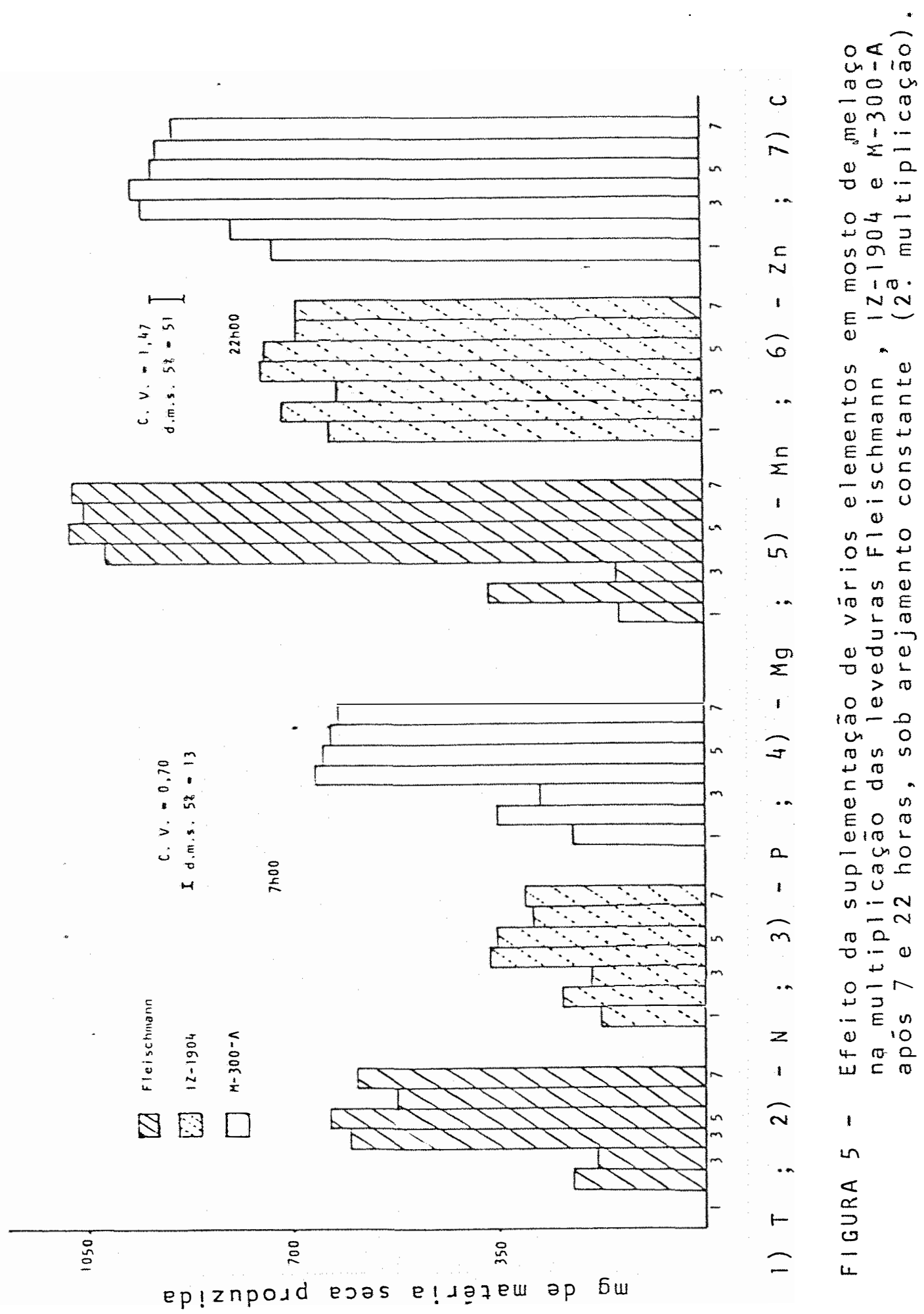


Na prātica, a falta desse elémento no mosto, in fluirā no tempo de produção de massa celular,jā que as sucessí vas gerações obtidas na multiplicação serão cada vez mais caren tes. Consequentemente a produção de álcool durante a multiplicação poderá ser relativamente maior, o que é um inconvenien te no início da safra, quando o ideal seria produzir só células e nada de álcool.

Tambëm DOS ANJOS MAGALHÁES et alii (1980) usan do mosto de melaço, encontrou um aumento no teor de proteina celular em Saccharomyces cerevisiae quando o teor de sulfato de amóneo no meio era aumentado.

Resultados semelhantes foram encontrados por FARAH ALVES e DEL BIANCO (1971) e VAIRO et alii (1975).

o menor teor de fósforo no mosto tambēm diminuiu a produção de massa seca pelas leveduras, embora de uma forma muito menos drāstica que o nitrogênio (Figuras 2, 3 , 4 e 5 , correspondentes as Tabelas $2,3,6$ e 7).

o efeito negativo da falta de fósforo foi mais evidente apös 7 horas que após 22 horas de multiplicação.

A não adição do fosforo aos mostos diminuiu a produção de matēria seca nas leveduras Fleischmann e M-300-A e em menor proporfão na levedura 12-1904 em mosto de xarope,o que pode também ser visualizado pelo açücar residual no vinho (Tabela 5). 
Tambēm quanto à fósforo, as leveduras Fleischmann e M-300-A foram as mais exigentes.

Quando não se adicionou o elemento magnésio, aos mostos (Figuras 2, 3, 4 e 5, correspondentes as Tabelas 1, 2,6 e 7), não houve alteração na produção de matēria seca, o que parece indicar que as quantidades médias de magnë sio já existente nos mostos usados, 0,0167\% (xarope) e 0,051\% (melaço), jà são suficientes.

Esses resultados concordam com os de DOS ANJOS MAGALHAES et alii (1980) que näo encontraram aumento de produ ção de proteína celular quando adicionaram sulfato de magné sio $\left(0,25 \mathrm{~g} / \ell\right.$ na forma de $\left.\mathrm{MgSO}_{4} \cdot 7 \mathrm{H}_{2} \mathrm{O}\right)$ em mosto de melaço.

Tambēm FULMER et alii (1921) verificaram que em meio sintētico, adições de sulfato de magnēsio atē $0,22 \%$ diminuiu o crescimento da levedura Fleischmann. Adições posteriores até $0,04 \%$ de sulfato de magnésio aumentou o cresci mento. Em concentrações de 0,04 à $0,1 \%$ de sulfato de magnésio não ocorreu diferença no crescimento, mas acima de $0,1 \%$ o crescimento foi diminuido.

Tambēm a adição de 10 ppm de zinco ao mosto não melhorou a produção de matēria seca pelas leveduras (Figuras $2,3,4$ e 5 , correspondentes as Tabelas $1,2,6$ e 7). Is so indica que as quantidades médias encontradas nos mostos 3,47 ppm (xarope) e 4,8 ppm (melaço) eram suficientes. 
Esses resultados não concordam com os de Mc HARGUE e CALFEE (1931) que encontraram que a melhor concentra ção de zinco no melo para o crescimento das leveduras fol 10 ppm. Também POPENKO e BAYAKHUMOV (1971) verificaram que o me Ihor crescimento das leveduras (strain $k_{2}$ e 15) foi na dose na dose de $30 \mathrm{mg}$ de sulfato de zinco por litro (12,l ppm de $\mathrm{Zn})$.

Por oltro lado os resultados concordam com os de OLSON e JOHNSON (1949) os quais encontraram que a Saccharo myces cerevisiae y-30 requer $200 \mathrm{microgramas}$ de zinco por litro de meio $(0,2 \mathrm{ppm})$ para o seu ótimo desenvolvimento. Densky et alii citado por REED e PEPPLER (1973) trabalhando com fermentação de cerveja em meios contendo de 0,05 a 0,1 ppm de $Z n$, verificaram que havia grande estimulo no crescimen to das leveduras se o meio fosse suplementado com zinco atë o nivel de $0,5 \mathrm{ppm}$. FREY et alii (1967) também quando adicionavam 0,5 ppm de zinco em meios de fermentação de cerveja con tendo de 0,04 a 0,07 ppm de zinco obtiveram grande estímulo, tanto na fermentação quanto no crescimento das leveduras.

Quanto ao manganès, a adição de lo ppm de mangạ nès aos mostos não aumentou a quantidade de matéria seca (Figuras $2,3,4$ e 5 , correspondentes às Tabelas.1, 2,6 e 7), o que indica que as quantidades médias encontradas no mos 
to 2,62 ppm (xarope) e 3,67 ppm (melaço) jā eram suficien tes

Esses resultados estão semelhantes aos encontra dos por limA (1953) que trabalhando com a levedura Iz-2 (sac charomyces cerevisiae, Hansen) concluiu que as doses mais re comendáveis de manganès para o crescimento da levedura foram 0,01 a 0,08 g de sulfato de manganès por litro, sendo ao redor de 0,01 (3,6 ppm de manganès) a dose ideal em condições de fer mentação.

Em mosto de xarope, todos os tratamentos com exceção do nitrogênio, diferiram da testemunha que não recebeu suplementação nenhuma, o que vem reforçar a afirmativa de que o nitrogénio é o elemento mais carente nos mostos de xaro pe utilizados e que portanto deve ser suplementado.

Como pode ser observado nas Tabelas 3 e 8 a por centagem de viabilidade das células obtidas tanto na multipli cação em xarope, quanto em melaço, foi elevada,podendo se afí mar que os niveis dos elementos usados nesse experimento, me mo os que afetaram a produção de matéria seca não afetaram a viabilidade das células.

As Figuras 6 e 7 , correspondentes às Tabelas 4 e 9 mostram as porcentagens de brotamento das células cres cidas em mosto de xarope e melaço suplementado com vários ele mentos. A porcentagem de brotamento foi marcadamente menor nos tratamentos testemunha e sem adição de nitrogênio. 


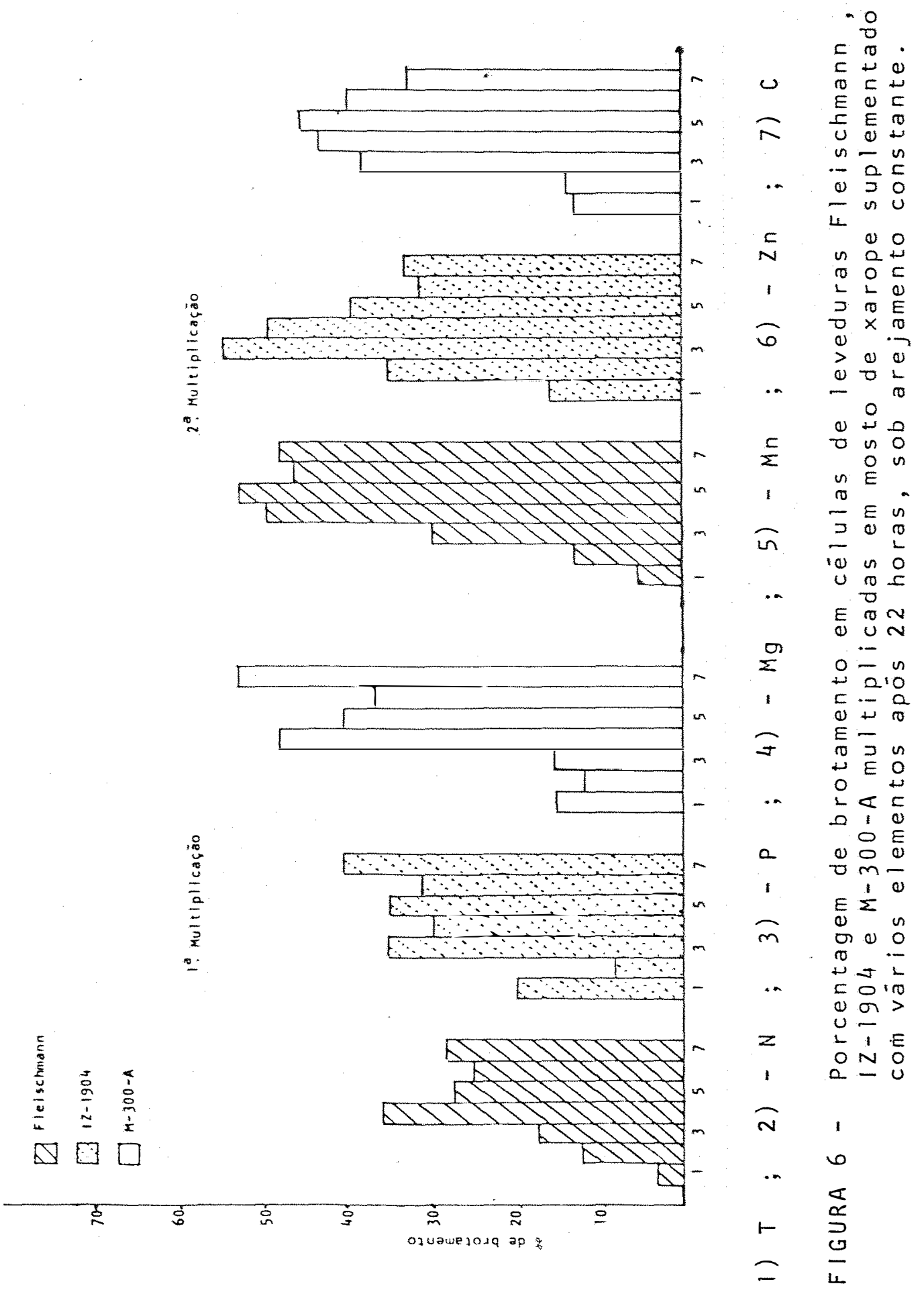




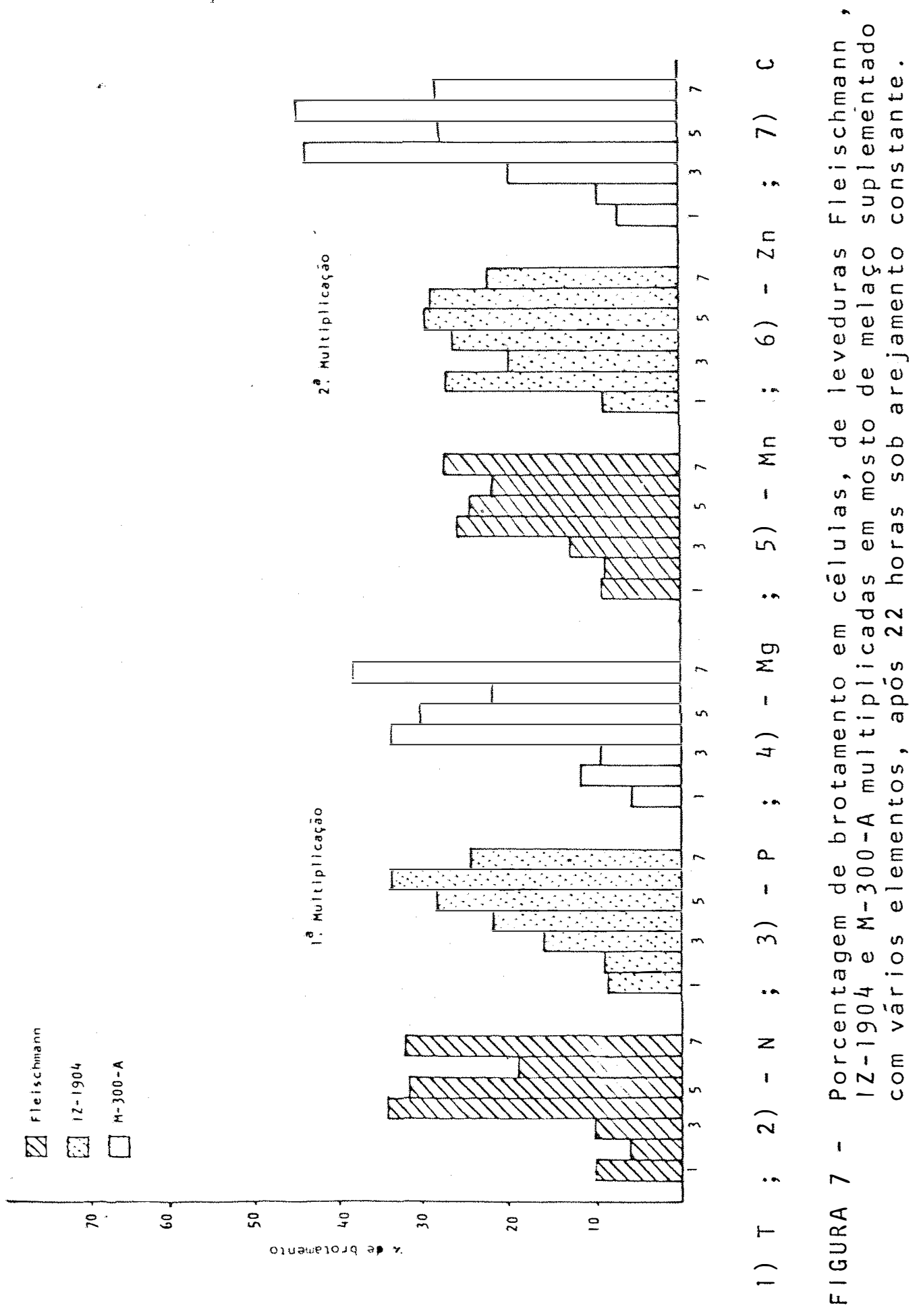


Nos tratamentos onde o fösforo não foi adicionado, embora com menor intensidade também foram afetados nega tivamente as porcentagens de brotamento, com exceção das leve duras 1Z-1904 e M-300-A em mosto de xarope.

Quando comparamos a produção de matéria seca produzida pelas très leveduras após 7 horas de multiplicação observamos que as leveduras Fleischmann e M-300-A produziram uma maior quantidade de matéria seca com a 1z-1904 (Figuras $2,3,4$ e 5 , correspondentes as Tabelas 1 e 6).

Essa diferença mais evidente durante o ensaio (apōs 7 horas) pode significar uma divisão celular mais lenta para a levedura 1Z-1904 quando comparada com as outras duas, nas condições do experimento.

os teores dos elementos analisados na matéria seca das leveduras, encontram-se nas figuras 8 a 17 , correspondentes às Tabelas 10 a 15.

Com referència à quantidade de nutrientes absorvidos pelas leveduras nos diversos tratamentos encontrou se de um modo geral, um comportamento semelhante entre as leveduras.

os menores teores de nitrogênio encontrados fo ram nas leveduras provenientes do tratamento testemunha e não suplementado con nitrogénio tanto em mosto de xarope como de melaço (Figuras 8 e 9 ). 


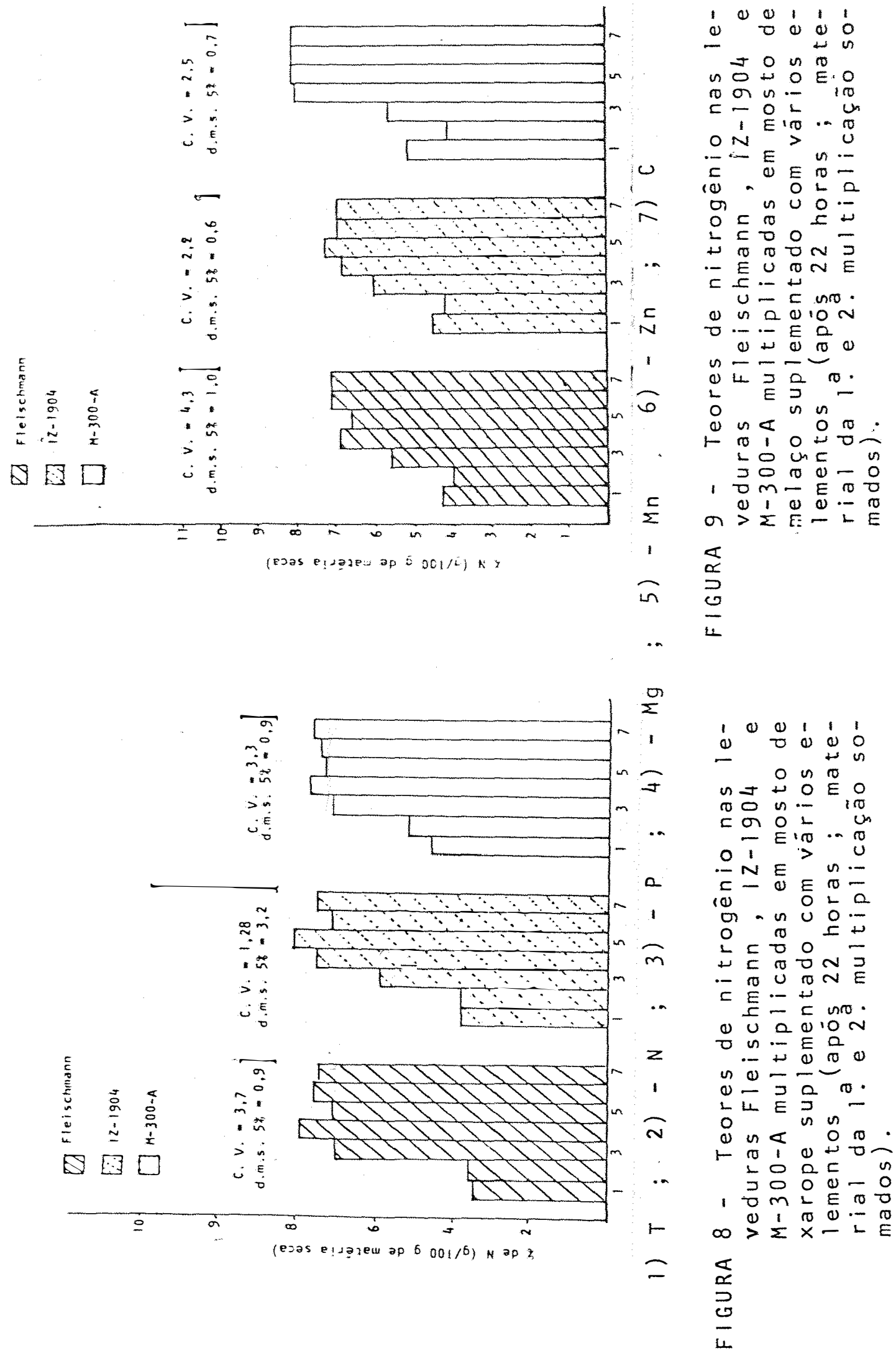


Em mosto de melaço as leveduras crescidas no tratamento não suplementado com fósforo também apresentaram um menor teor de nitrogênio, embora de uma forma menos acentuada que nos tratamentos testemunha e não suplementado com nitrogê nio.

OLIVEIRA E SOUSA (1970) encontraram uma correlação altamente significativa entre fósforo e nitrogênio em le veduras e explicou através da intervenção do fósforo no siste ma ADP - ATP, influindo no metabolismo nitrogenado.

As Figuras 10 e 11 mostram as quantidades de potássio analisado nas leveduras multiplicadas em mosto de xa rope e melaço que receberam a suplementação dos vários elemen tos em questão.

o tratamento que evidenciou uma tendência de acümulo de potássio foi o deficiente em nitrogènio. Isso parece ser mais devido ao fato de que nesse tratamento o fósfo ro foi adicionado na forma de fosfato monoácido de potássio o que elevou a concentração de potássio no meio.

Entretanto, o baixo teor de nitrogénio no meio pode ter favorecido uma maior absorção de potássio. Segundo EVANS e SORGER (1966) os íons amônio e potássio são quimicamente parecidos sendo essa semelhança observada em reações bio químicas, onde o amônio pode substituir o potássio na ativaf̧ão de várias enzimas "in vitro". 


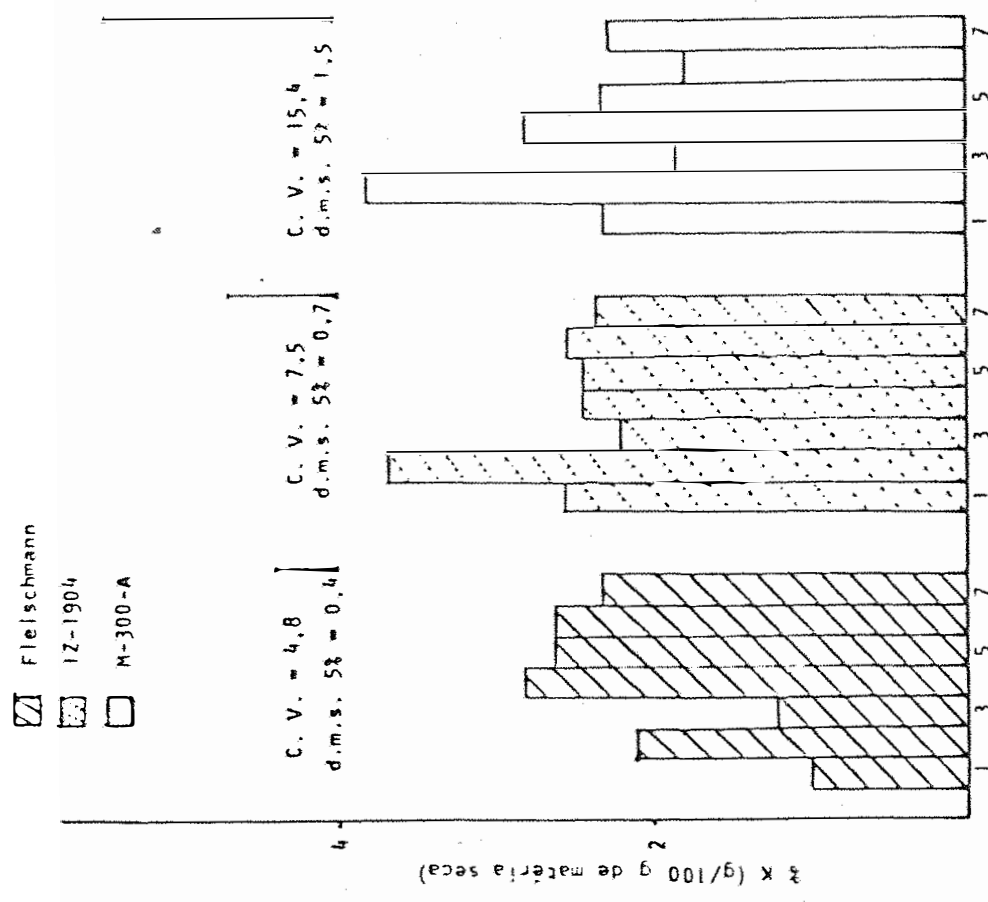

$\begin{array}{llllll}1 & 0 & 0 & 1 & 1 & 1 \\ 0 & 0 & 0 & 0 & 0 \\ 2 & 0 & 0\end{array}$

I 0 un

T.

u 0 n

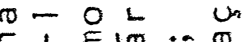

CI EITO

$O N E$ n. U

N $\quad \begin{array}{lllll}0 & n & E & 0 & 0 \\ n & 0 & 0 & 0\end{array}$

i $10=0$ 工

w $匚 00=$

O

E. -

o U - C nRo.

$N \quad 0$ un a

- $E Q$

n $0+\infty \quad 00$

$0-\cdots-1$

(1) ठㄴ

$\stackrel{0}{1} u<\stackrel{0}{n} 0.0$.

i 10 更

วO

O M-

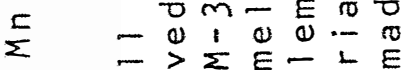

in $\frac{\sigma}{a}$
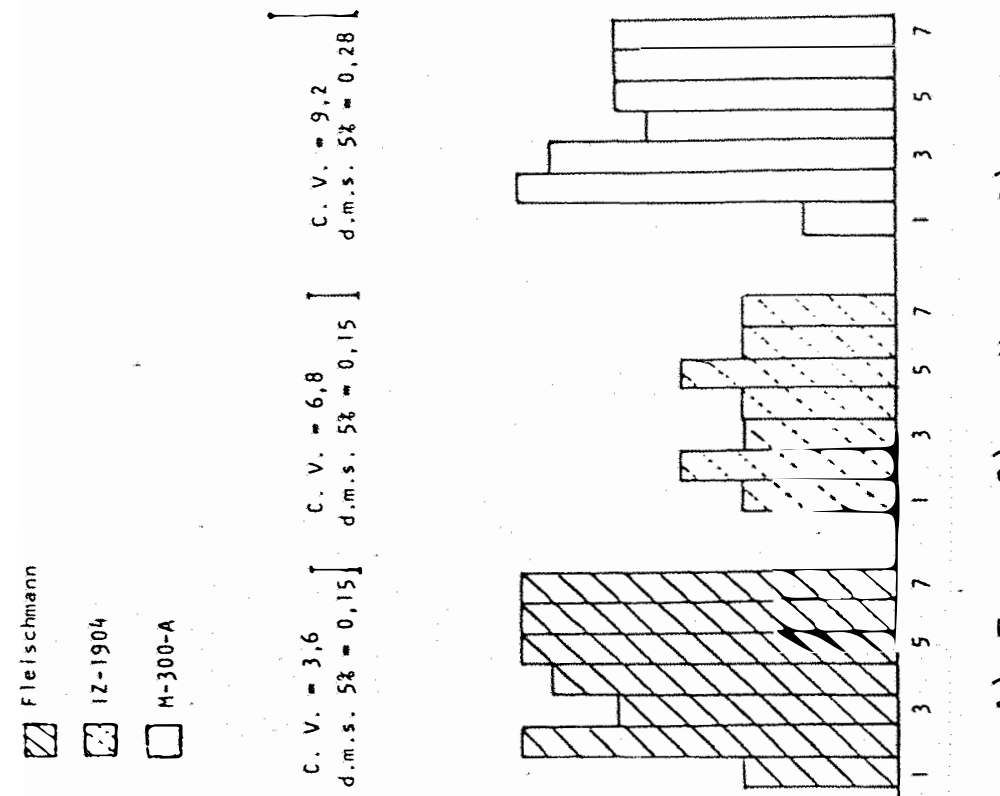

$\begin{array}{llllll}1 & 0 & 0 & 1 & 1 & 1 \\ 1 & 0 & 0 & 0 & 0\end{array}$

- 0 un

O D O EO

u $n$ n..

r - O L

in un

$C N E I N \cdots \sigma$

$O N E^{>} n$

U $O$ E L D

u u u O -

in $ᄃ 0 \leq+$

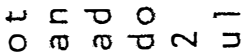

口EU TO

ᄃ.. $+\infty$

(1) U - I nRo.

0 in a $0.0 \mathrm{~N}$

-. E

ज $0+0$ O 0

14乚 Ј

$\stackrel{0}{\leftarrow} n \ll$ n $n$ r $\begin{array}{lll}0 & 1 & 0\end{array}$ $\div 005-0$

1 J 0 O

0010.00

$\frac{\pi}{2}$ 
No tratamento não suplementado em fösforo houve um menor acúmulo de potássio pelas leveduras, em mosto de mel aço.

As Figuras 12 e 13 mostram os teores de fósforo analisados nas leveduras crescidas em mosto de xarope e me laço suplementado com os vários elementos em questão.

Conforme poderia ser esperado as leveduras obtidas nos tratamentós testemunha e não suplementado em fósfóro foram os que apresentaram um menor teor desse elemento.

As quantidades de fósforo analisadas nas leveduras crescidas em mosto de xarope não suplementado em $N$ foram significativamente baixos, enquanto nas crescidas em mosto de melaço os niveis encontrados foram semelhantes ao tratamen to completo. Como o melaço possui um teor de nitrogēnio supe rior ao xarope, talvez o nivel existente foi suficiente pa ra uma absorção normal de fósforo pelas leveduras.

As Figuras 14 e 15 mostram o teor de magnésio, encontrado nas leveduras multiplicadas em mosto de xarope e melaço suplementados com os vários elementos em questão.

No tratamento que não recebeu a suplementação de fósforo as leveduras analisadas apresentaram de um modo ge ral menor teor de magnésio. 

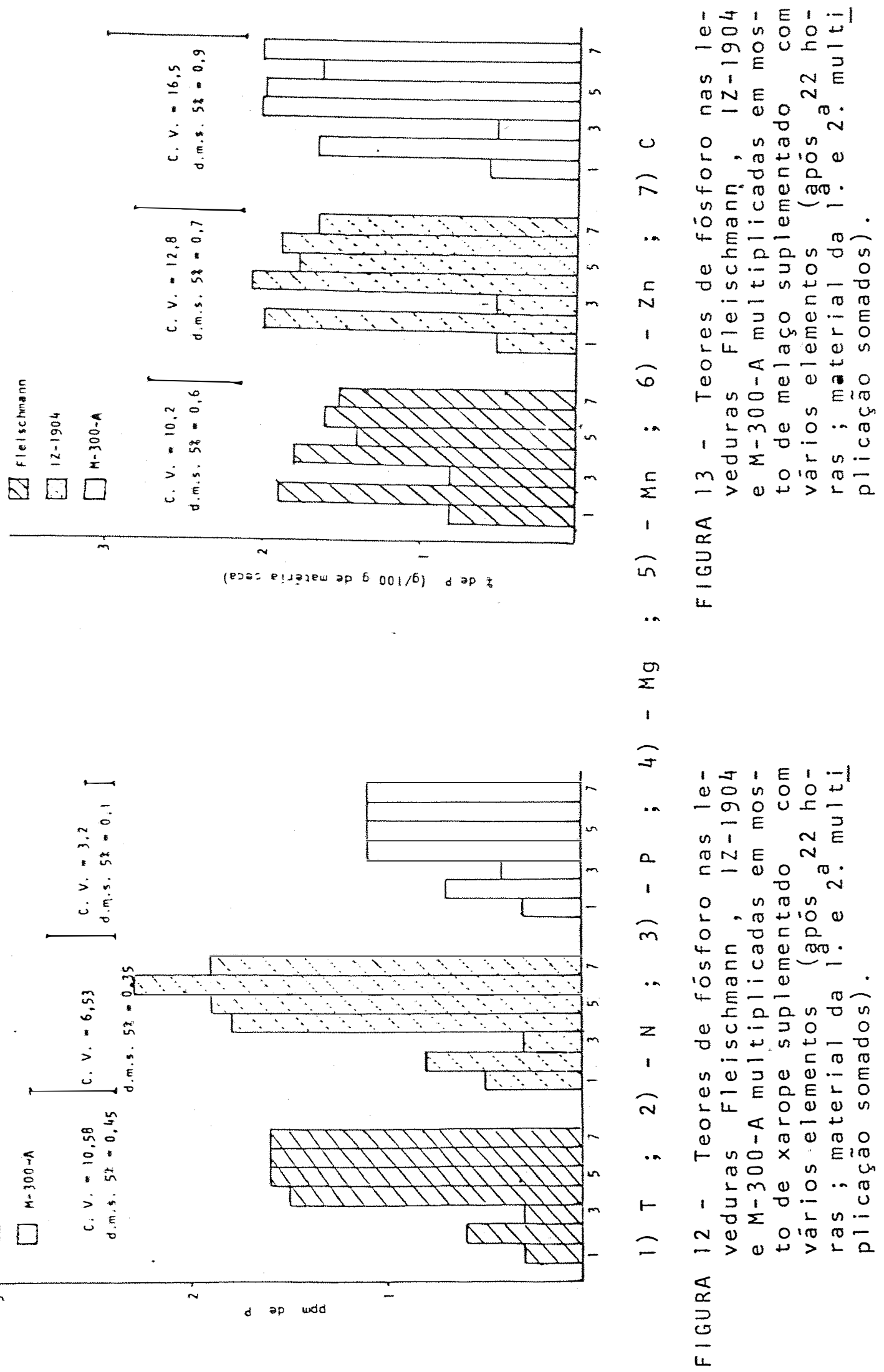

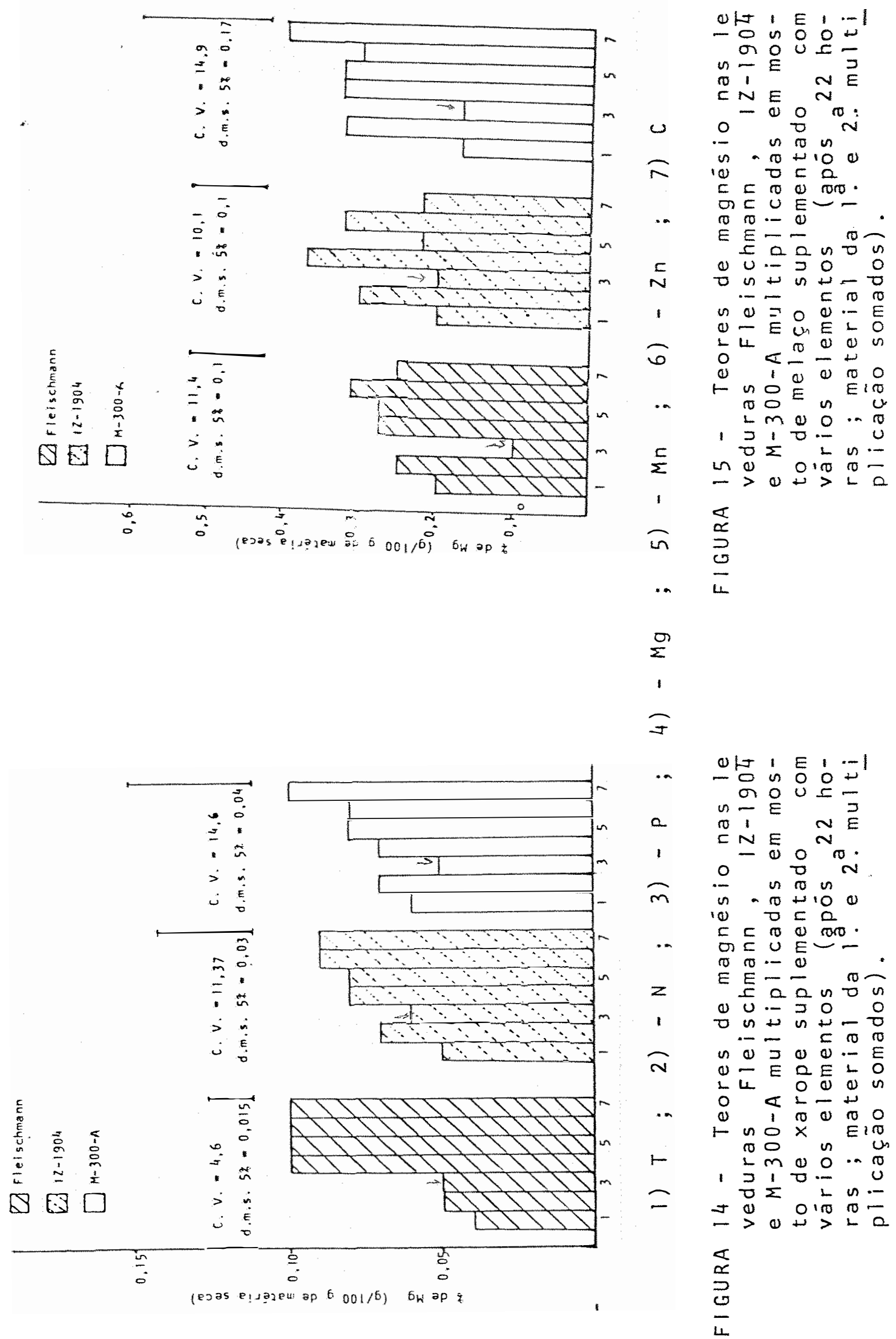
OLIVEIRA e SOUSA (1970) encontraram correlação entre o conteúdo de magnésio e o de fósforo em Candida utizis e afirmaram que a correlação com o magnésio é muito importante, devido ao papel do magnésio no transporte ativo e a intervenf̧ão do fósforo sobre a síntese dos carregadores.

As Figuras 16 e 17 mostram os teores de zinco encontrados nas leveduras multiplicadas nos mostos de xarope e melaço suplementados com oś vários elementos em questão.

As anālises de zinco nas três leveduras utilizadas revelaram um acümulo de zinco pelas células. A levedura $12-1904$ apresentou neste aspecto ser diferente das outras duas, pois o acúmulo de zinco nessa levedura foi notave mente superior. Essa super acumulação de zinco fol observada anteriormente por LAWFORD et alii (1980.a) em Candida utiZis, e constataram que esse super acūmulo de zinco não era inibitório ao crescimento.

Nos tratamentos testemunha e não suplementado em zinco as leveduras apresentaram um teor mais baixo de zinco. 0 fato de que nas leveduras do tratamento testemunha, o teor de zinco analisado foi sempre um pouco maior que nas do tratamen to deficiente em zinco, pode ser explicado pelo efeito da diluição, pois no tratamento onde não se colocou zinco mas se co locou os outros elementos o teor de matéria seca produzida foi muito maior que na testemunha. 

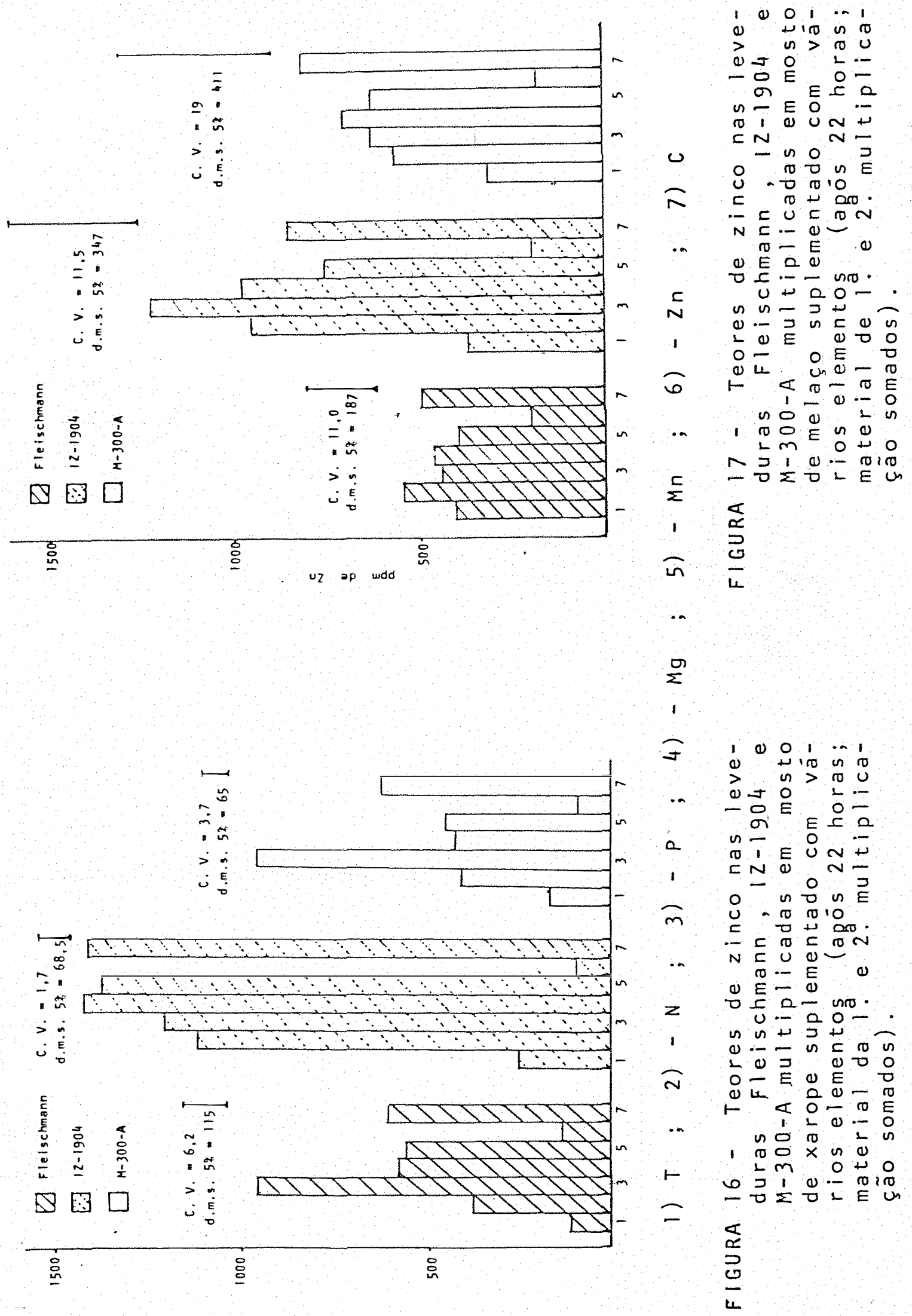
Ainda, quando se observa as Figuras 16 e 17 pode-se notar que as leveduras Fleischmann e M-300-A em mosto de xarope e Fleischmann e IZ-1904 em mosto de melaço, apresentaram um maior acūmulo de zinco no tratamento onde se suprimiu o fósforo. Talvez haja menor absorfão de zinco nos tratamentos mais elevados em fósforo devido à precipitação do zinco na forma de fosfato de zinco. OLIVEIRA e SOUSA (1970), afirmam ocorrer a’ formação de fosfatos insolúveis de zinco, alumínio, ferro e manganês nas células de leveduras e LAWFORD e PIK (1980.a) afirmam ser os polímeros de polifosfato acumulado nas células possíveis agentes armazenadores de zinco. No presente caso, talvez a insolubilização do zinco pelo fósforo fora da célula seja a causa principal deste resultado.

Resultado obtido por alguns pesquisadores, em plantas, evidenciaram esse efeito antagōnico entre fósforo e zinco. MOTSARA (1974) utilizando isótopo radioativo de zinco verificou que o fósforo induziu uma imobilização do micronutriente na superfície radicular do milho e cevada. MALAVOLTA e LOPEZ GOROSTIAGA (1974) trabalhando com raízes e plantas de cevada verificaram que na presença de fosfato havia inibição não competitiva na absorção de zinco e precipitação de zinco na superficie das raízes. 


\section{2 - Efeito da Suplementação de Nitrogênio e Fósforo em Diferentes Niveis, em Mosto de Karope, na Multipli caćão das Leveduras Fleischmann, IZ-1904 E M-300-A}

Estatisticamente os resultados obtidos para os tratamentos com nitrogènio, foram independentes dos niveis de fósforo (Figuras 18,19 e 20 , correspondentes às Tabelas $16,17,18,19,20$ e 21).

Considerando os resultados obtidos apös 7 horas de multiplicação, podemos perceber um aumento significati vo de mátéria seca até a dose de 400 ppm de nitrogênio, o que indica que quanto maior a dose de nitrogênio usada, tem-se maior quantidade de células em menor tempo.

Apōs 22 horas de multiplicação, a quantidade de matéria seca produzida não aumentou nas doses superiores a 200 ppm de nitrogênio, para a levedura Fleischmann.

A produção de matéria seca obtida das leveduras 1Z-1904 e M-300-A foi crescente com o aumento das doses de nitrogênio tanto às 7 como às 22 horas de multiplicação.

A baixa produção de células nos tratamentos 0 e 100 ppm de nitrogēnio podem ser confirmadas pelo açūcar residual dos vinhos obtidos (Tabelas 22,23 e 24)

Acima da dose de 100 ppm o.consumo de açūcar foi total. 


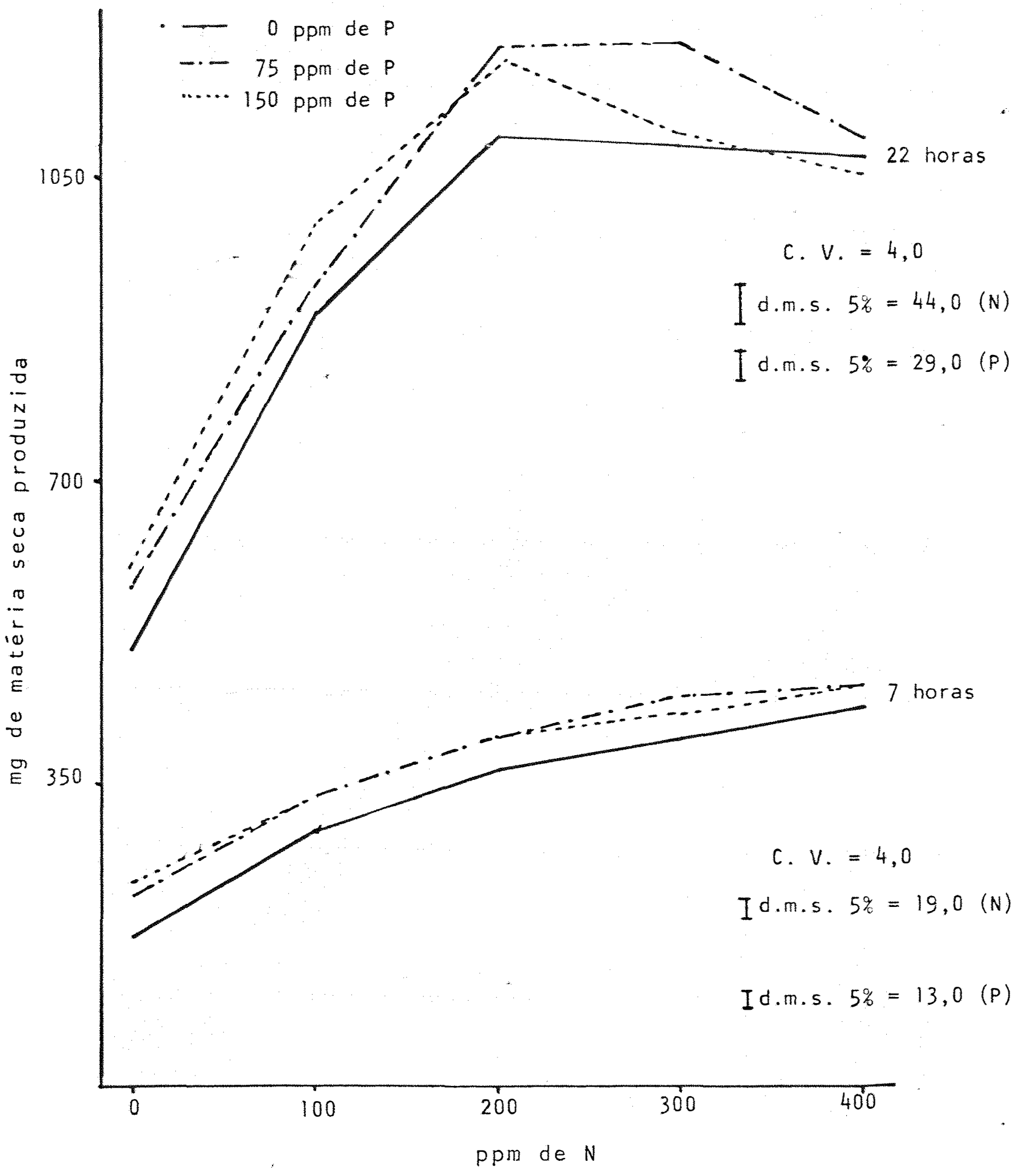

FIGURA 18 - Efeito da suplementação de nitrogēnio e fósforo em diferentes niveis, em mosto de xarope na multiplicação da leveduráfleischmann, após 7 e 22 horas sob arejamento constante. 


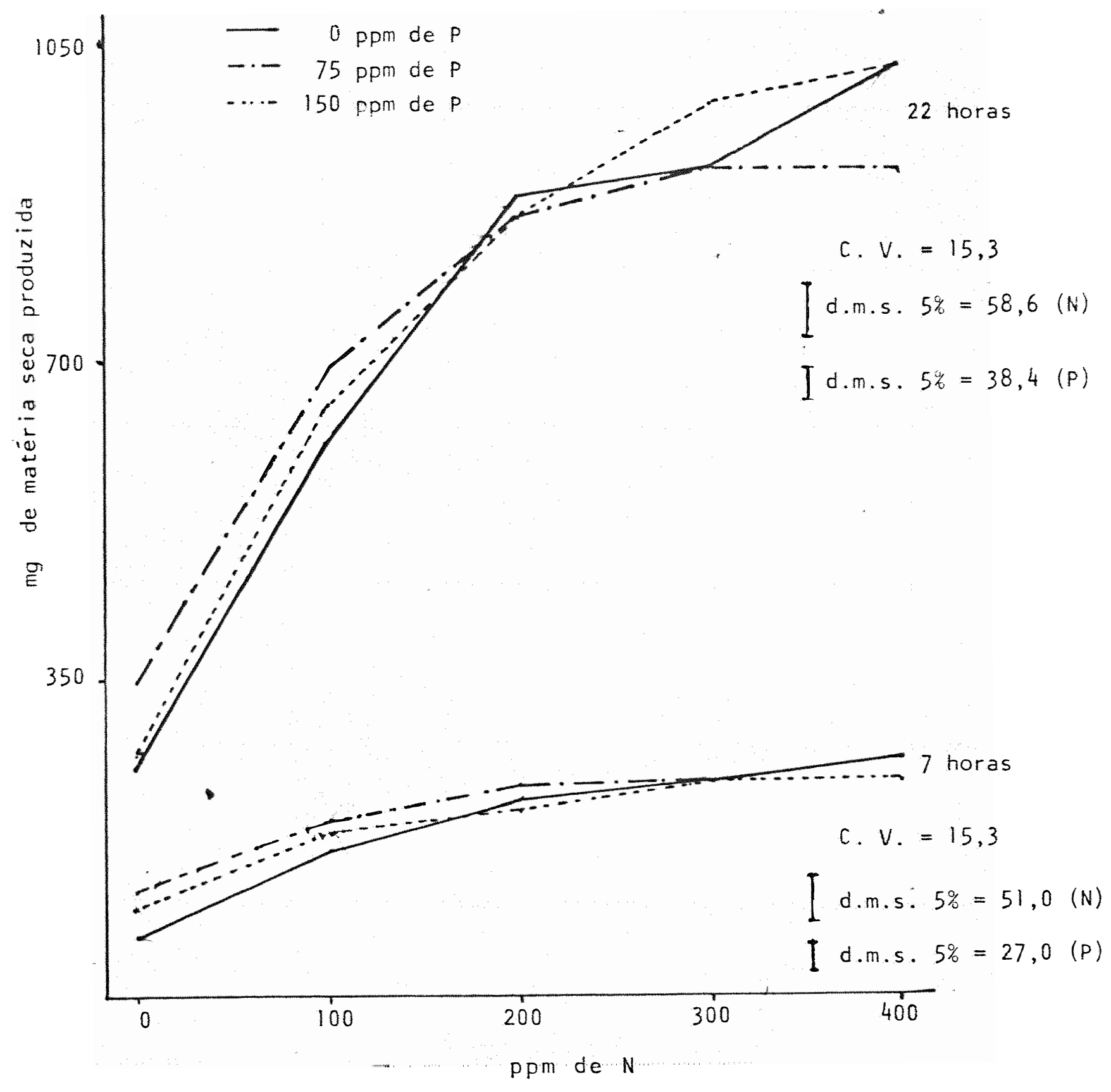

FIGURA 19 - Efeito da suplementação de nitrogènio e fósforo em diferentes niveis em mosto de xarope na multiplica ção da levedura $12-1904$, após 7 e 22 horas sob arejamento constante. 


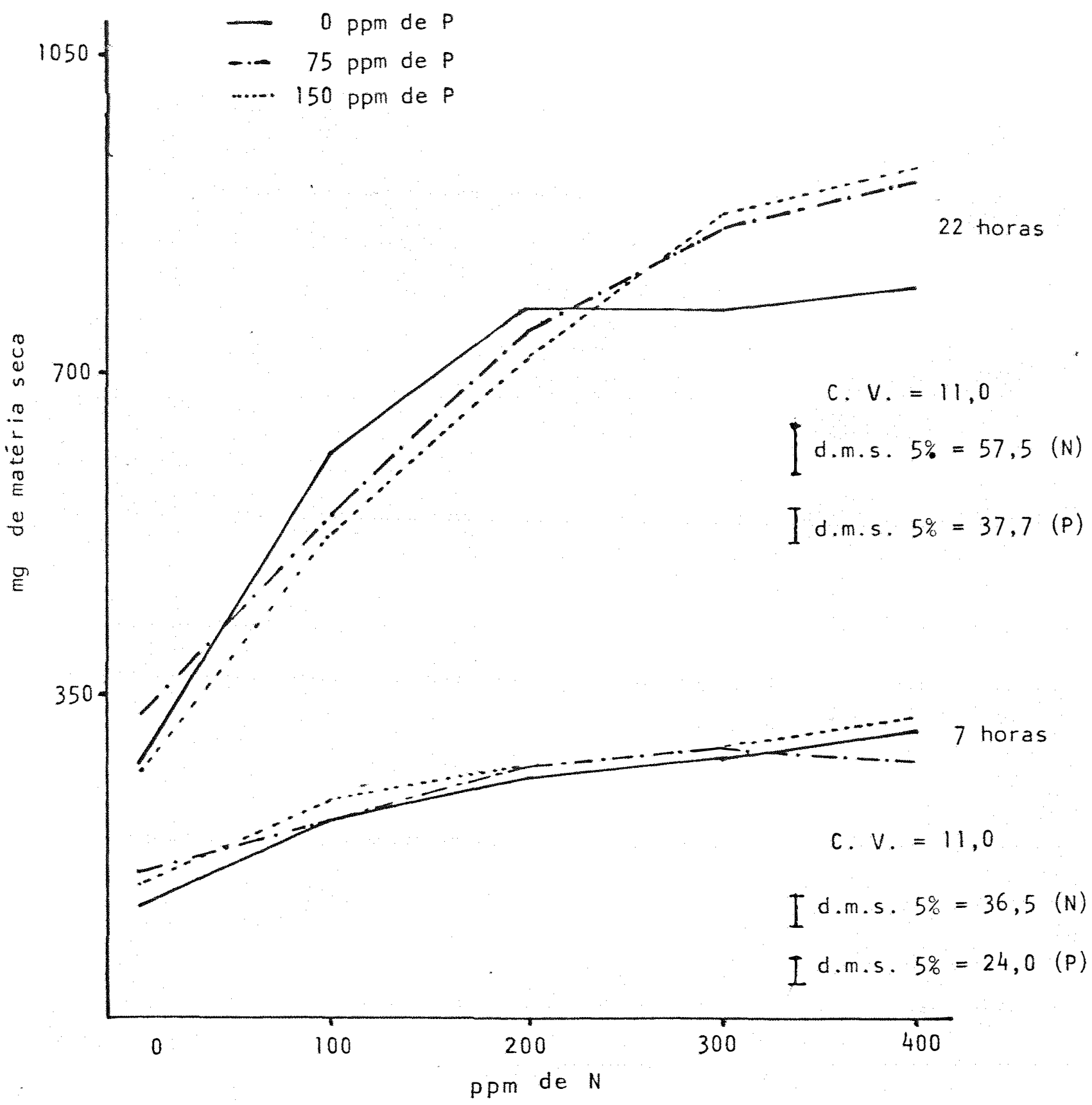

FIGURA 20 - Efeito da suplementação de nitrogēnio e fósforo em diferentes niveis em mosto de xarope na multiplica ção da levedura M-300-A após 7 e 22 horas, sob are jamento constante. 
Esses resultados. São semelhantes aos apresen tados por FULMER et alii (1921) que afirma que a dose ótima de nitrogènio para o crescimento das leveduras è $0,060 \%$ de amónio ( 466 ppm de N).

Tambēm Fulmer (1925) citado por DEVEREUX e TAN NER (1927) encontrou que o ótimo de concentração de $\mathrm{NH}_{4} \mathrm{Cl}$ para o crescimento da levedura foi de $1,88 \mathrm{~g} / 1$ (492 ppm de $\mathrm{N}$ ).

o fōsforo influiu significativamente na produ彑 fão de matéria seca da levedura Fleischmann, na dose de 75 e 150 ppm quando comparadas com o tratamento não suplementado em fósforo. Nas leveduras IZ-1904 e M-300-A embora houvesse um aumento de matéria seca nas doses de 75 e 150 ppm este não foi significativo.

FULMER et alii (1921), trabalhando com meio sin tético, verificaram que as dosagens de fósforo que aumentavam o crescimento eram bem baixas (atē 35,6 ppm). Adições de fós foro acima dessa dose até 1.050 ppm de fósforo, não al teraram a produção de rassa celular.

DOS ANJOS MAGALHAES et alii (1980) trabalhando com mosto de melaço não encontraram aumento no teor de proteí nas quando adicionaram fosfato de sōdio 258 ppm de fósforo aos mostos utilizados e inferiram que nas condiçós em que fo ram realizados os seus ensaios, só o nitrogênio era o fator I imitante. 
os dados referentes a porcentagem de viabilida de celular encontram-se nas Tabelas 25,26 e 27.

A porcentagem de células viáveis para as três leveduras foi boa e parece não ser influenciada pelos sais utilizados.

Por outro lado, percebe-se claramente a influen cia dos sais nitrogenados no brotamento das células, isto é, quanto maior a quantidade de nitrogénio usado, maior a porcen tagem de brotamento (Figura 21 , correspondente às Tabelas 28 , 29 e 30 ).

A porcentagem de células em brotamento na leve dura M-300-A foi mais baixa que nas outras duas. Esse fato pa rece indicar que a levedura M-300-A atingiu a fase estacionária de multiplicação muito mais rápido que as outras duas leveduras, portanto cessando a sua multiplicação.

Na levedura M-300-A a tendència foi de aumentar a porcentagem de brotamento quando se elevou o teor de fós foro no meio de 0 para 75 ppm de fósforo, nas doses de 300 e 400 ppm de nitrogènio.

0 postamente nas leveduras Fleischmann e $12-1904$ a quantidade de células em brotamento de uma maneira geral de cresceram com o aumento do nível de fósforo.

os teores dos elementos analisados na matéria seca das leveduras encontram-se relacionados nas figuras 22 a 31 , correspondentes às Tabelas 31,32 e 33. 


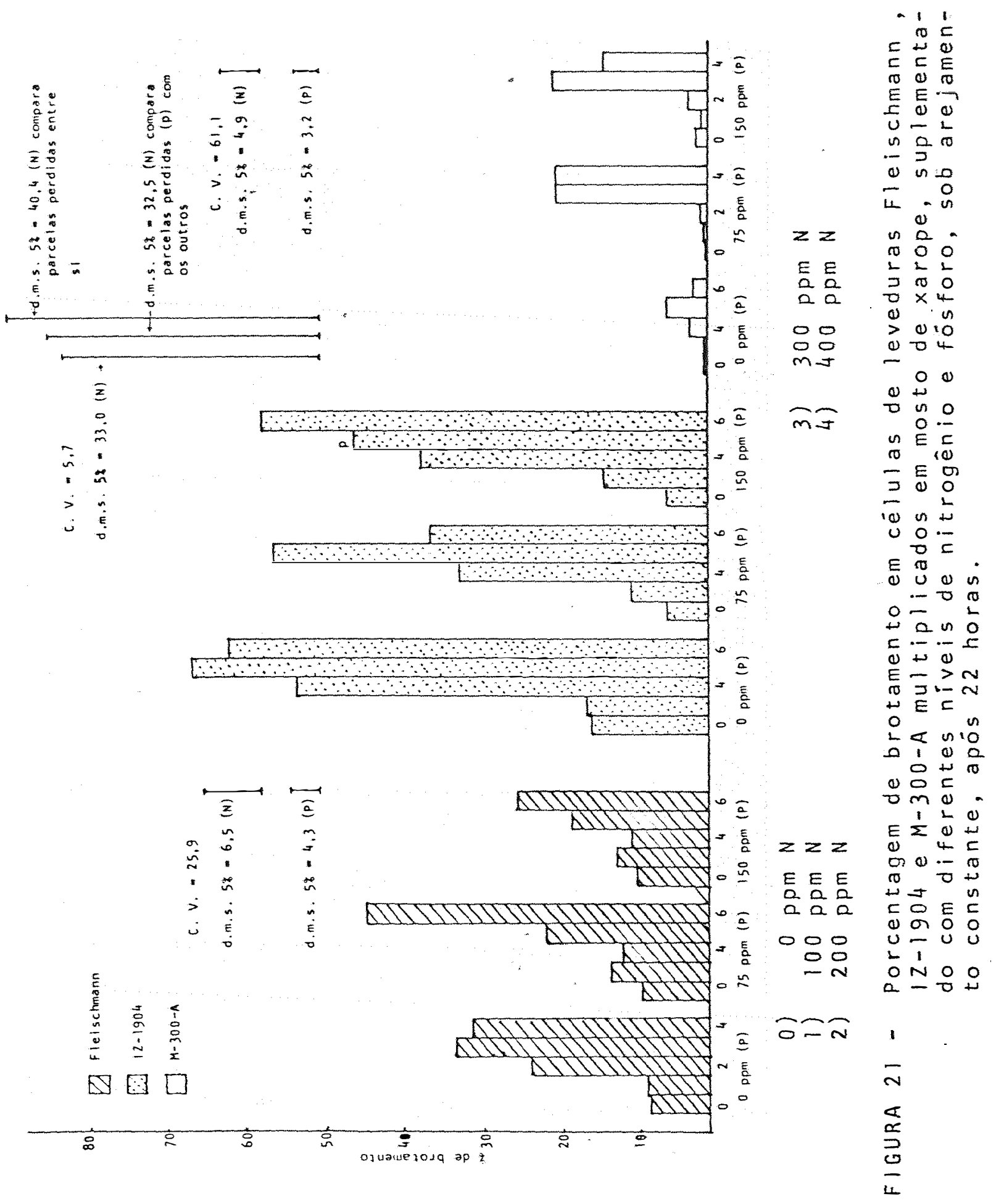


Quanto à análise mineral podemos verificar que os teores de nitrogénio analisados na matéria seca das levedu ras cresceram até a dose de 400 ppm no mosto (Figuras.22, 23 e 24), o que significa que os componentes orgánicos nitrogena dos, tais como aminoácidos, proteínas, ácidos nucléicos, também tiveram os seus teores aumentados, permitindo uma multiplicação celular muito mais intensa.

As quantidades de nitrogénio éncontradas nas le veduras no tratamento 400 ppm de nitrogénio estão dentro da faixa normal, que segundo WHITE (1954) é de $8,5 \%$ na matéria se ca .

os trēs níveis de fösforo empregados não influ ram no acúmulo de nitrogēnio pelas leveduras utilizadas. Esses resultados não concordam com os de FARAH ALVES e DEL BIAN co (1971) que afirmam ter a adição de fosfato em mosto de melaço provocado sensível melhora na assimilação do nitrogénio pela levedura.

As Figuras 25 e 26 mostram a interação entre as doses de nitrogènio e fósforo no mosto e a quantidade de fósforo encontrada na matéria seca das leveduras fleischmann e 12-1904. Houve correlação positiva entre a dose de nitrogēnio no mosto e a dose de fósforo encontrada nas leveduras. E ses resultados evidenciam que a maior aplicação de nitrogènio resulta numa maior produção de compostos nitrogenados, muitos dos quais, contendo ou requerendo fósforo para a sua formação. 

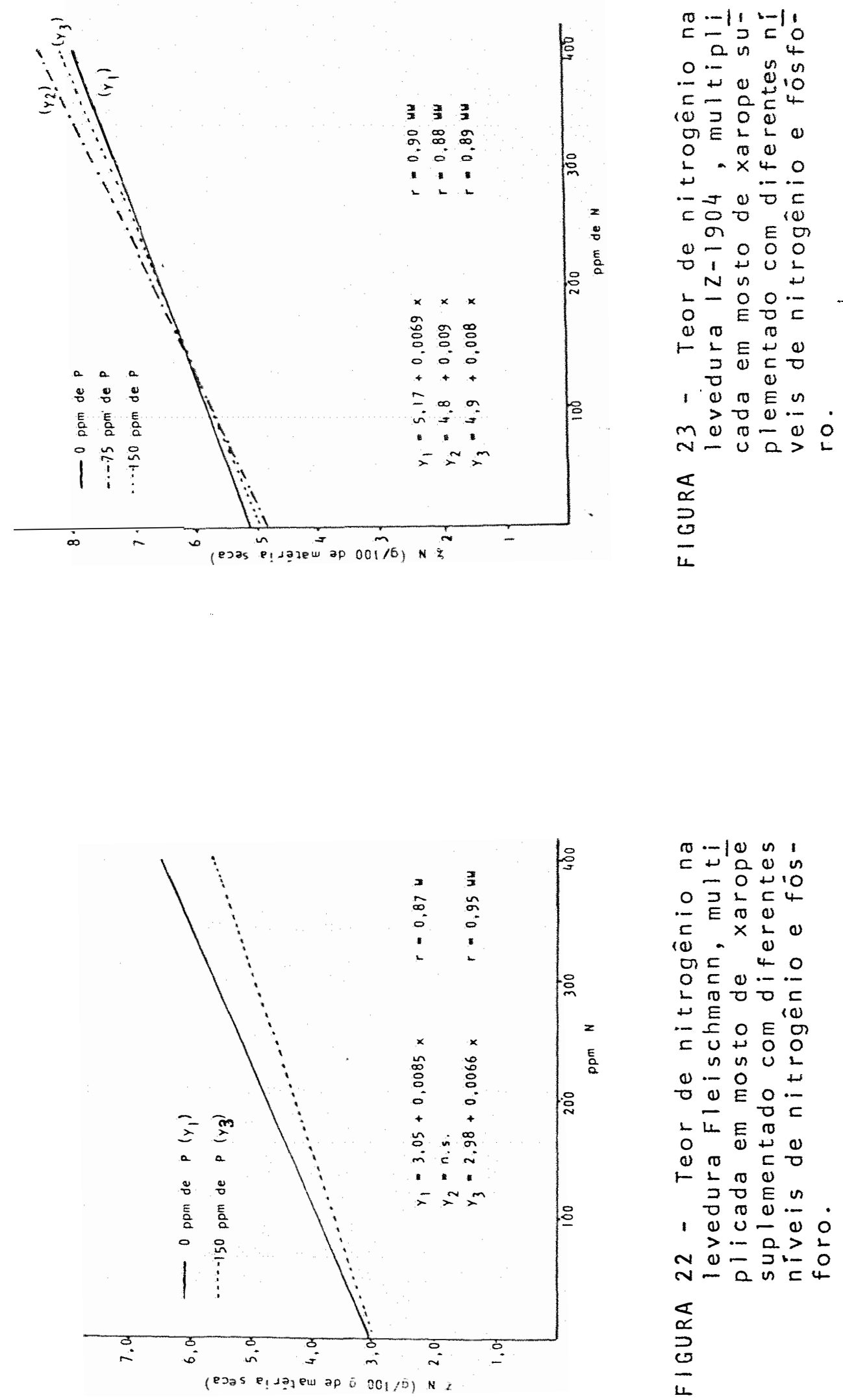

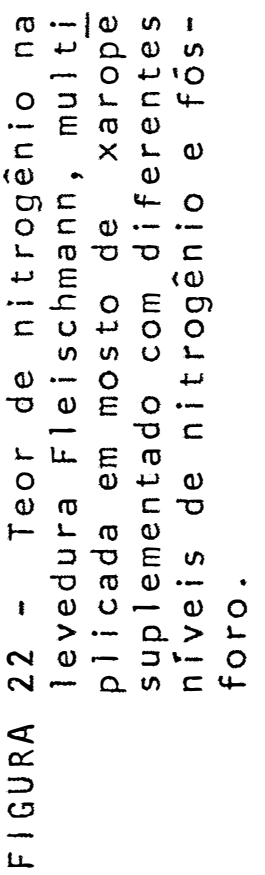




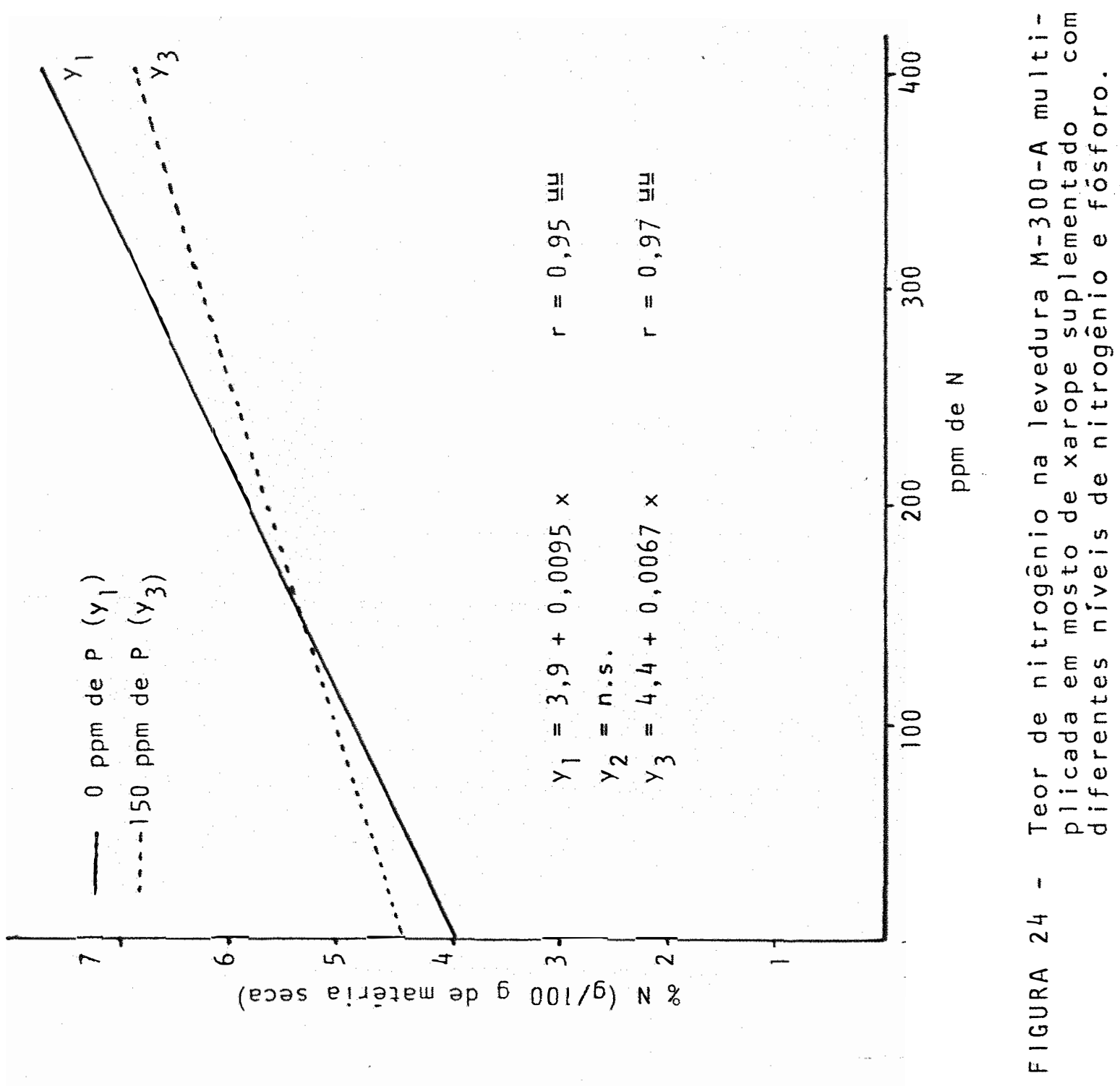



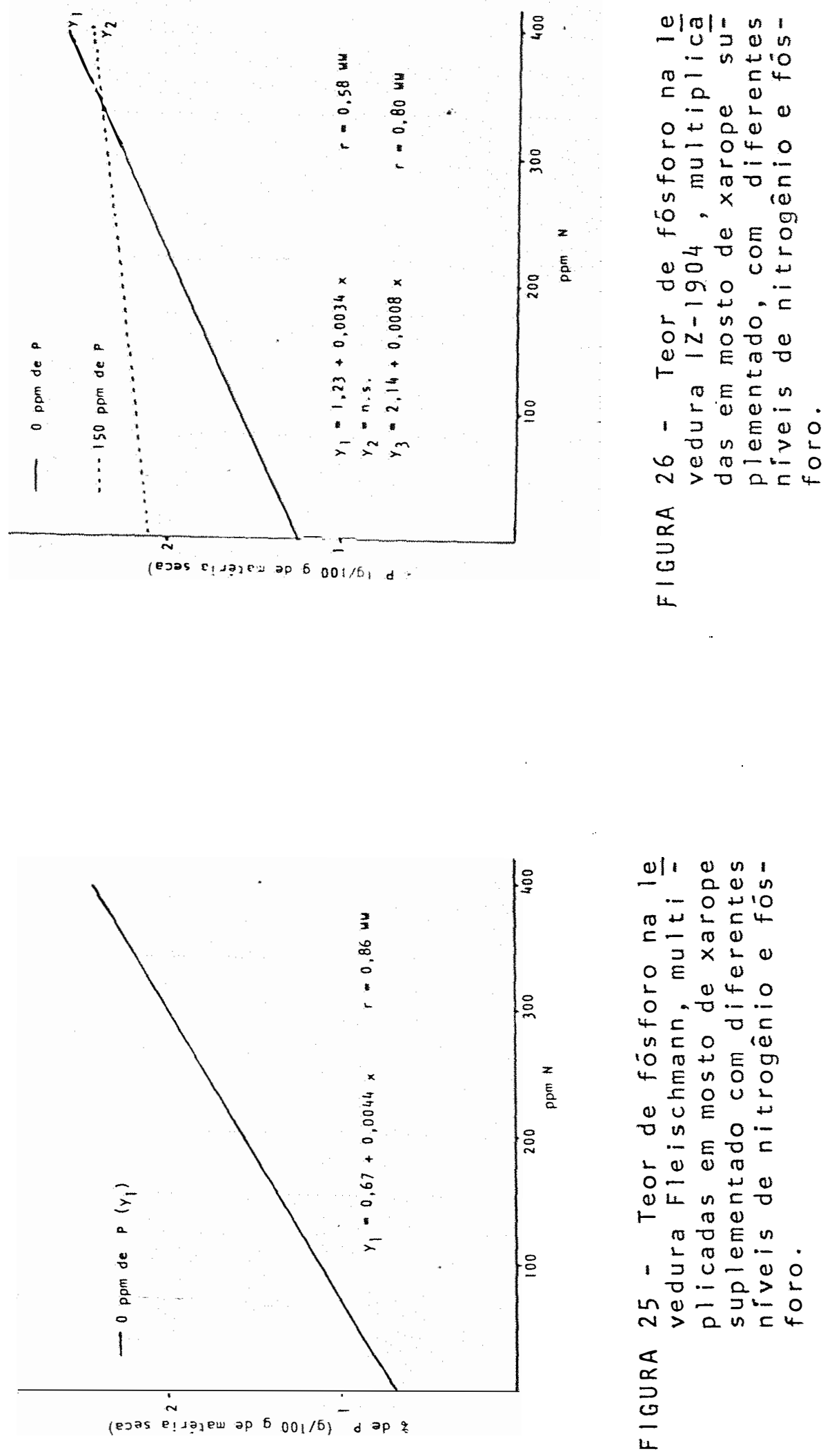
Desta maneira, um aumento na absorção de nitrogénio, resulta também num maior acūmulo de fósforo. Resultados semelhantes foram encontrado em leveduras por OLIVEIRA e SOUSA (1970). Um maior acúmulo de fósforo em meio contendo mais nitrogénio tam bém pode ser observado em plantas superiores (HEWITT, 1963). Quanto ao potássio absorvido pelas leveduras os resultados mostram um decréscimo no teor de potássio das leve duras $12-1904$ e M-300-A quando se eleva o teor de nitrogênio no mosto (Figuras 27 e 28). A interação entre esses dois nutrientes, tem sido mais estudado em plantas. Em planta de to mate, MAYNARD et alii (1968) verificam um antagonismo do nitrogènio sobre o potássio quando nitrogènio era fornecido na forma amoniacal. PIETZ et alii (1978) encontraram uma correlação negativa entre doses de fertilizantes nitrogenados empregados e o teor de potássio nos grãos de milho.

os resultados encontrados nas anälises de magnésio na matéria seca das leveduras fleischmann e M-300-A (F guras 29 e 30 ) parecem indicar uma absorf̧ão diferente quando se varia nitrogènio dentro dos niveis de fósforo usado. Quan do não se adicionou fósforo ao mosto houve elevação do magnésio, encontrado nas leveduras, conforme se elevou o nível de nitrogênio no mosto. Quando foi adicionado fósforo ao mosto houve um decréscimo nos teores de magnésio encontrados. 

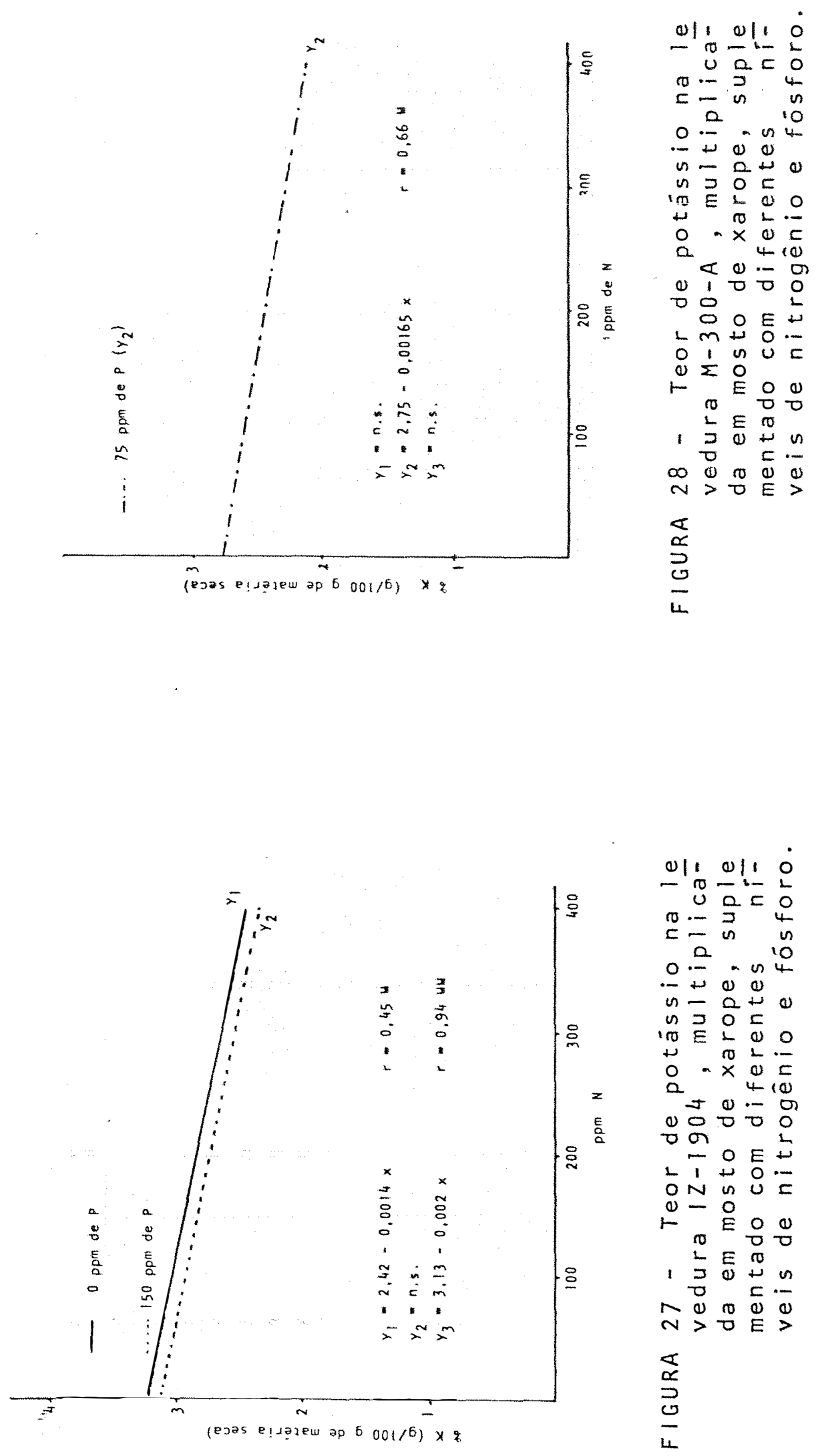

0110110

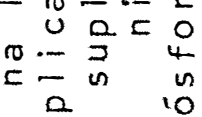

o. - n 4

$\because \begin{array}{llll}0 & 0 & 0 & 0\end{array}$

n $\supset 0=$

in $E$ L 10

$+\cdots \frac{1}{1}=$

$0 . \times 410$

$0 \div 000$

o क 1

1 - 1 E

ON in U E

$\stackrel{0}{-} \stackrel{0}{E} 00$

- ${ }_{0} E O 0$

LE

$1 \geq 0+\cdots$

$N 0000$

$N>D E>$

$\frac{\sigma}{\omega}$ 

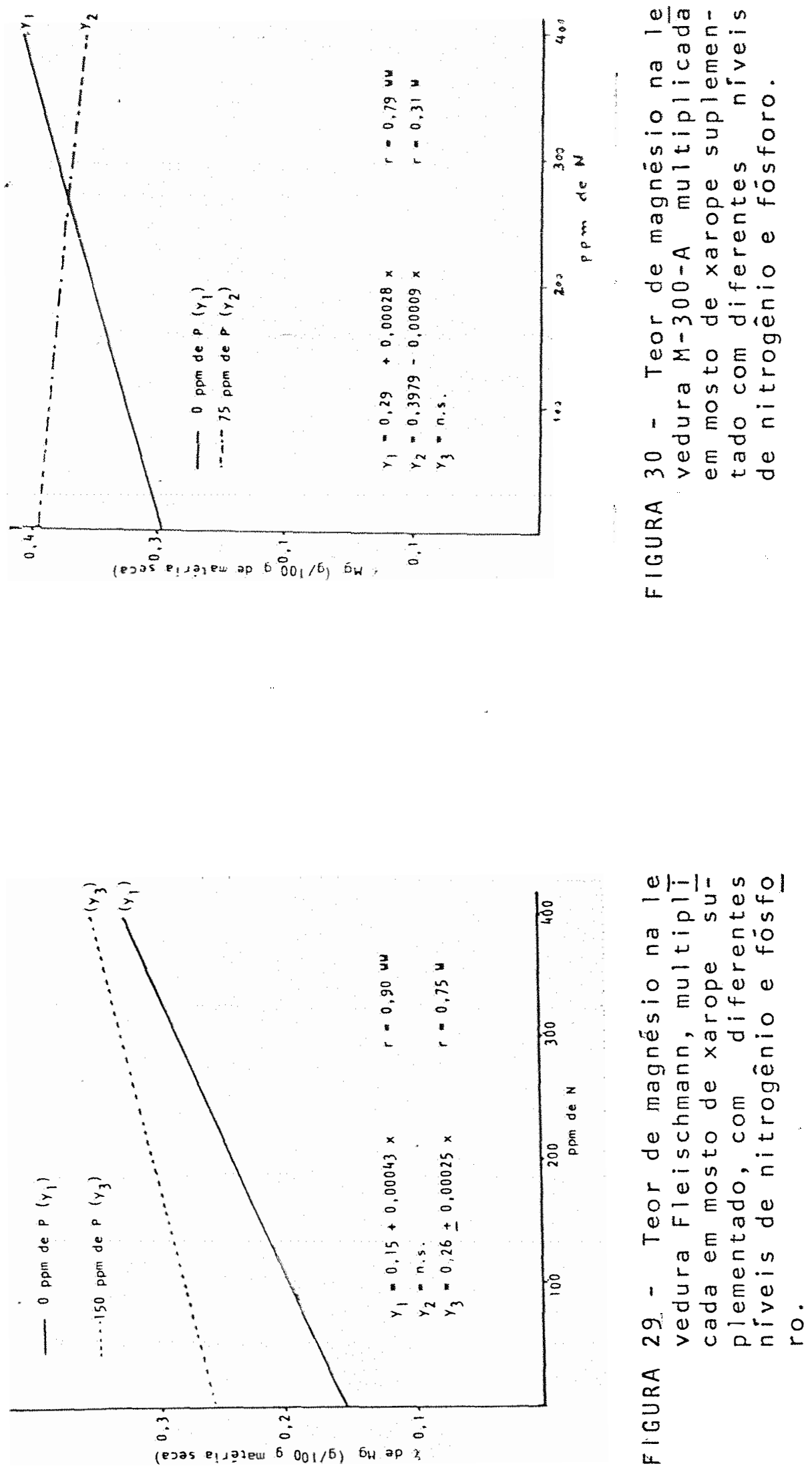
Esses resultados näo concordam com JENNINGS et alii (1958) que afirmam que as células adquirem maior capacidade para absorver magnésio, quando fosfato está presente no meio, talvez porque neste ültimo trabalho as condições de deficiència tenham sido mais drāsticas.

Por outro lado se considerarmos que quando se aumentou a dose de fósforo também se aumentou a dose de potás sio, pois o fósforo foi colocado na forma de fosfato monoācido de potássio, uma inibição de absorção de magnésio pode ter ocorrido com o aumento da concentração de potássio no meio.

o aumento da absorf̧ão de magnésio ocorrida quan do se aumentou o teor de nitrogénio no mosto, na dose de 0 ppm de fósforo,pode ser explicado pelo aumento do fösforo na leve dura nas doses crescentes de nitrogēnio. JENNINGS et alii (1958) sugere um carregador de magnésio e manganès dependente de fösforo e afirma que somente uma pequena fração do fosfato que en tra na célula está envolvida na formação dos carregadores de magnèsio e manganès, jā que a maior parte do fosfato absorvido é considerado na forma de polifosfato, ATP e intermediá rios glicolíticos.

Quanto ao manganês, os teores determinados na matéria seca das leveduras 1Z-1904 e M-300-A foram crescente com o aumento das doses de nitrogènio no mosto (Figuras 31 e 32 ). 

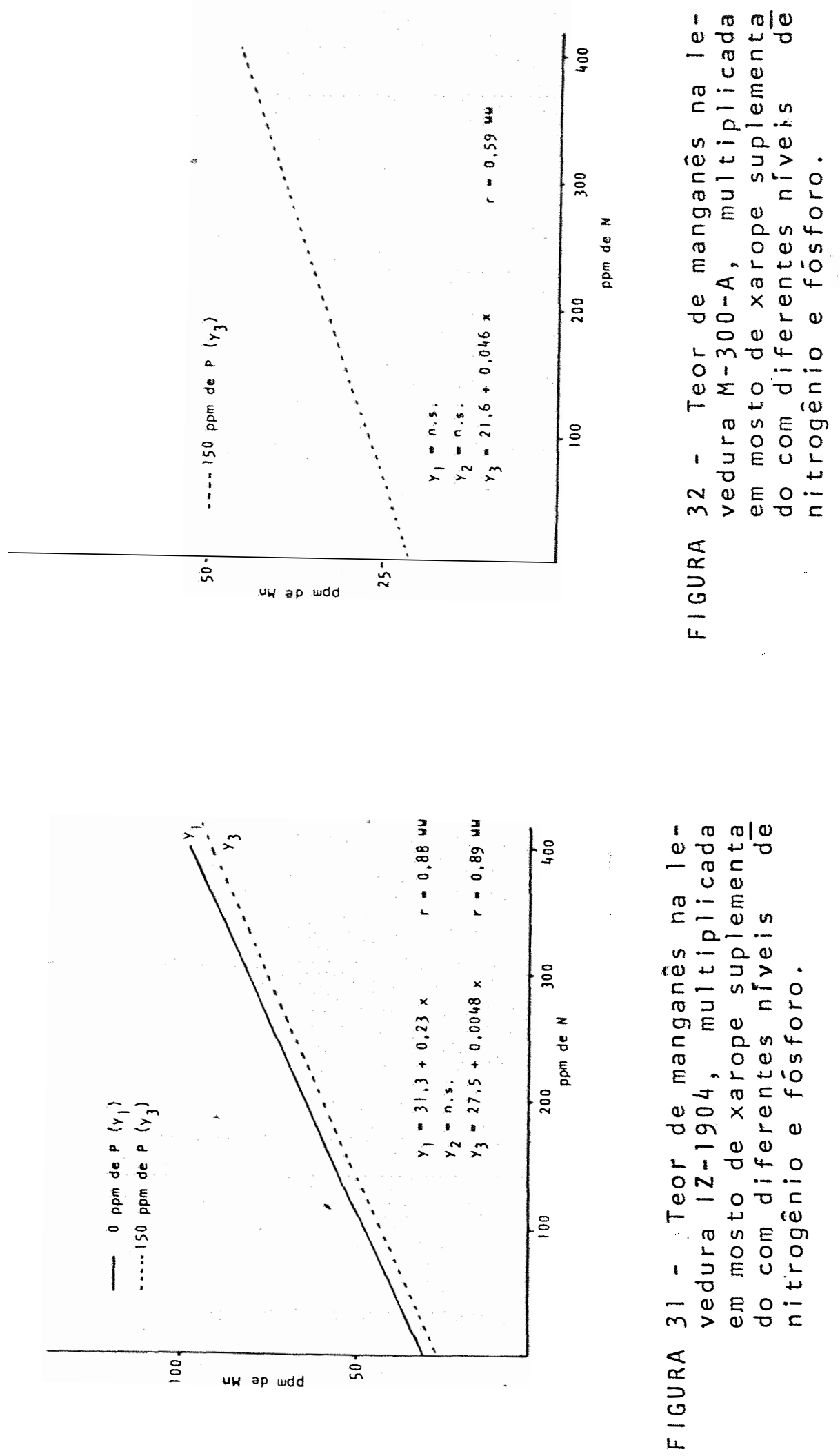
Essa maior absorção de manganês parece estar ligada ao fato de que com o aumento das doses de nitrogènio no mosto, o fösforo foi mais acumulado nas leveduras.

JENNINGS et aZii (1958) mostra que um carregador de fosfato é sintetizado durante a atividade glicolítica. Em con traste, o carregador de manganês não pode ser sintetizado somente pela atividade glicolítica, o que o leva a sugerir que - carregador de manganès é um composto fosforilado formado na membrana celular como um produto direto dos sistemas de trans ferència de fosfato (carregadores de fosfato).

As quantidades de zinco analisadas na levedura 1Z-1904 decresceram quando se elevaram as doses de nitrogènio no mosto (Figura 33).

Esses resultados diferem dos apresentados por OLIVEIRA e SOUSA (1970) que afirmam aumentar o nível de zinco na levedura quando se aumenta o nível de nitrogénio com mosto de lixívia bissulfítica. Tambèm se considerarmos a elevaf̧ão do nível de fosfato nas cēlulas quando se elevou os níveis de nitrogènio os resultados obtidos não concordam com os de LAWFORD e PIK (1980.a) que conferem aos polifosfatos acumulados nas células de leveduras possíveis agentes de armazenamento de zinco. 


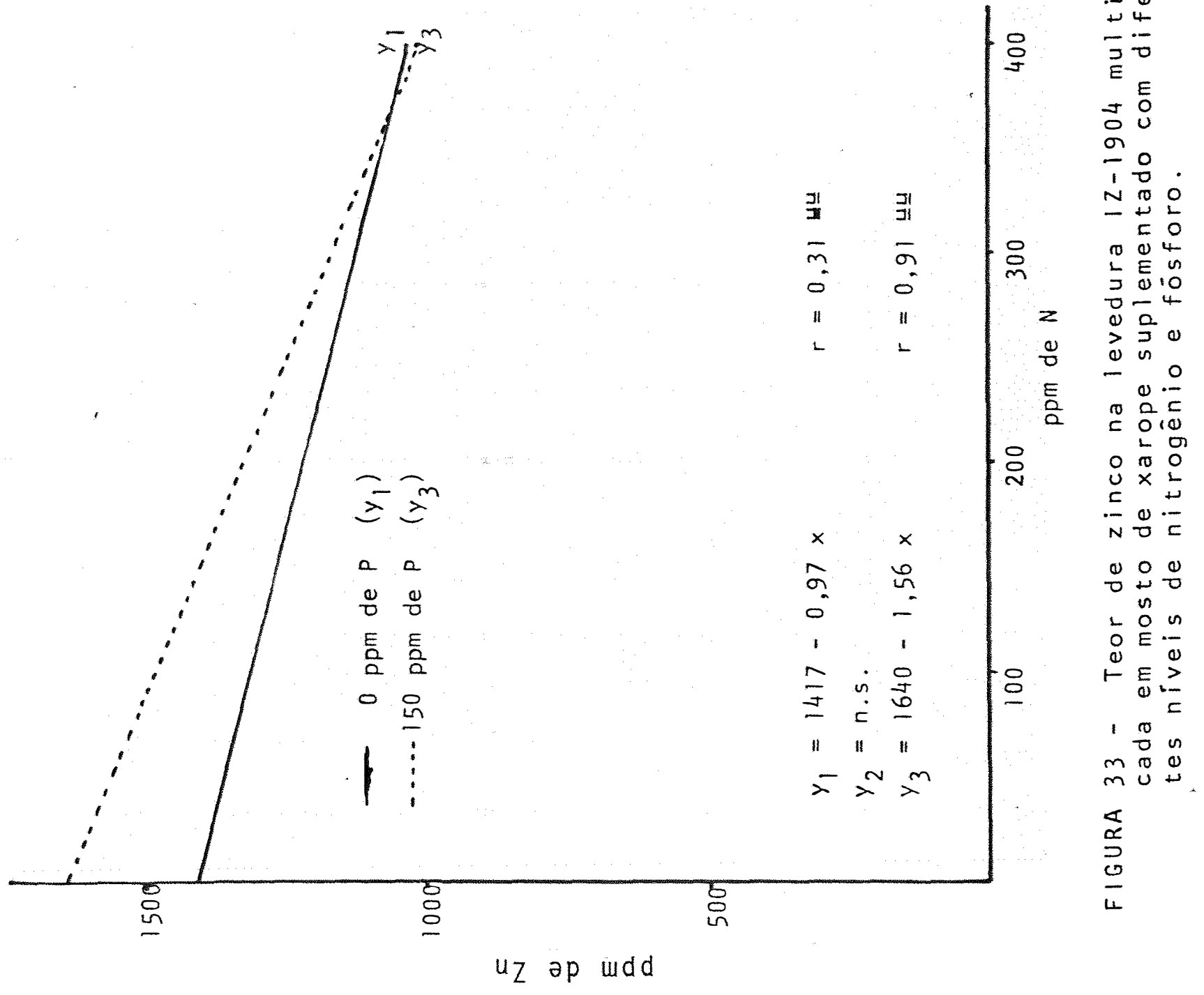




\section{3 - Relacão entré Porcentagem de Brotamento e Matéria Seca Produzida}

As Figuras 34,35 e 36 correspondentes às Tabelas 34,35 e 36 mostram a interação entre a porcentagem de brotamento e matéria seca produzida nas leveduras fleischmann, 1Z-1904 e M-300-A, respectivamente.

A grande dispersão dos pontos se deve ao fato de ter-se reunido todos os dados obtidos nos diversos experi mentos realizados para se fazer essa correlação.

Percebe-se que houve uma correlação positiva significativa entre quantidade de matéria seca produzida e por centagem de brotamento, para as très leveduras, sendo a que a melhor correlação foi para 12-1904. Isso indica que a anälise da porcentagem de brotamento é importante quando se preten de uma alta quantidade de levedura em pouco tempo, pois quanto mais células em brotamento houver, maior será a utilização dos açúcares para a produção de células. Por outro lado, este indice pode ser adotado para o controle da multiplicação com uma dose de confiança razoàvel.

A melhor correlação obtida com os dados da levedura $12-1904$ parece estar ligado ao fato de que esta levedu ra desenvolveu menos, atingindo a fase estacionária mais tar de que as outras duas. 


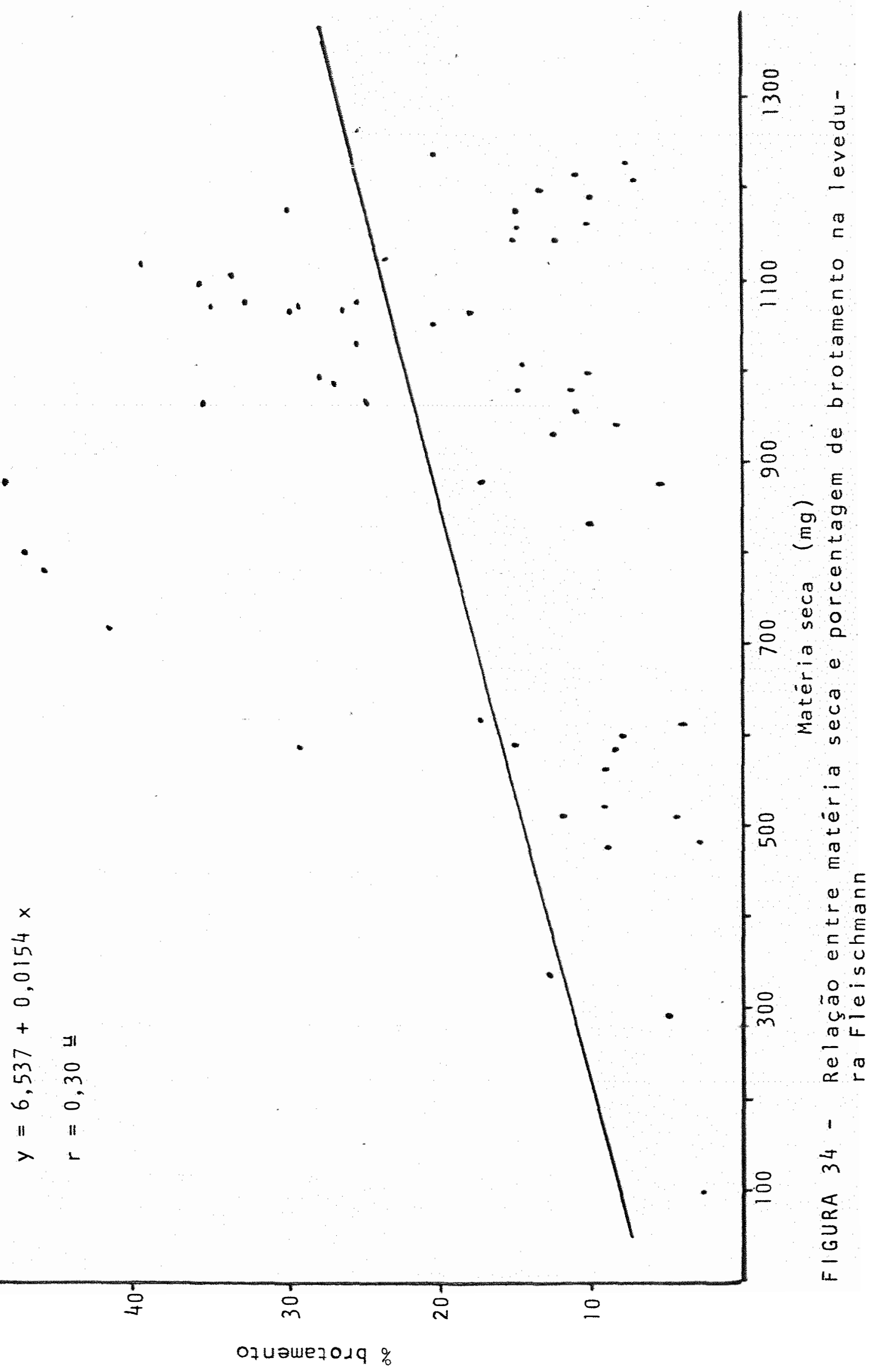




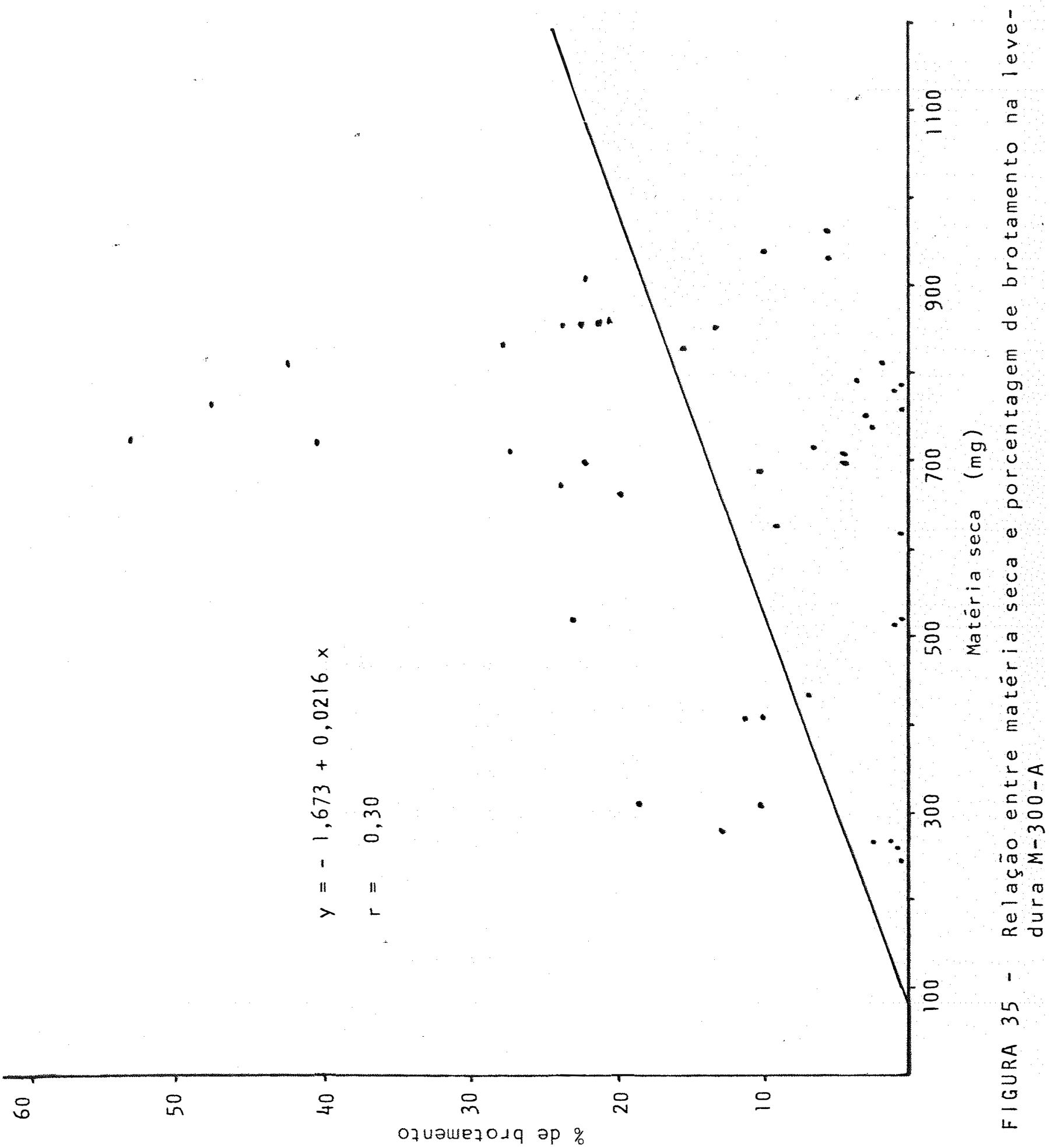




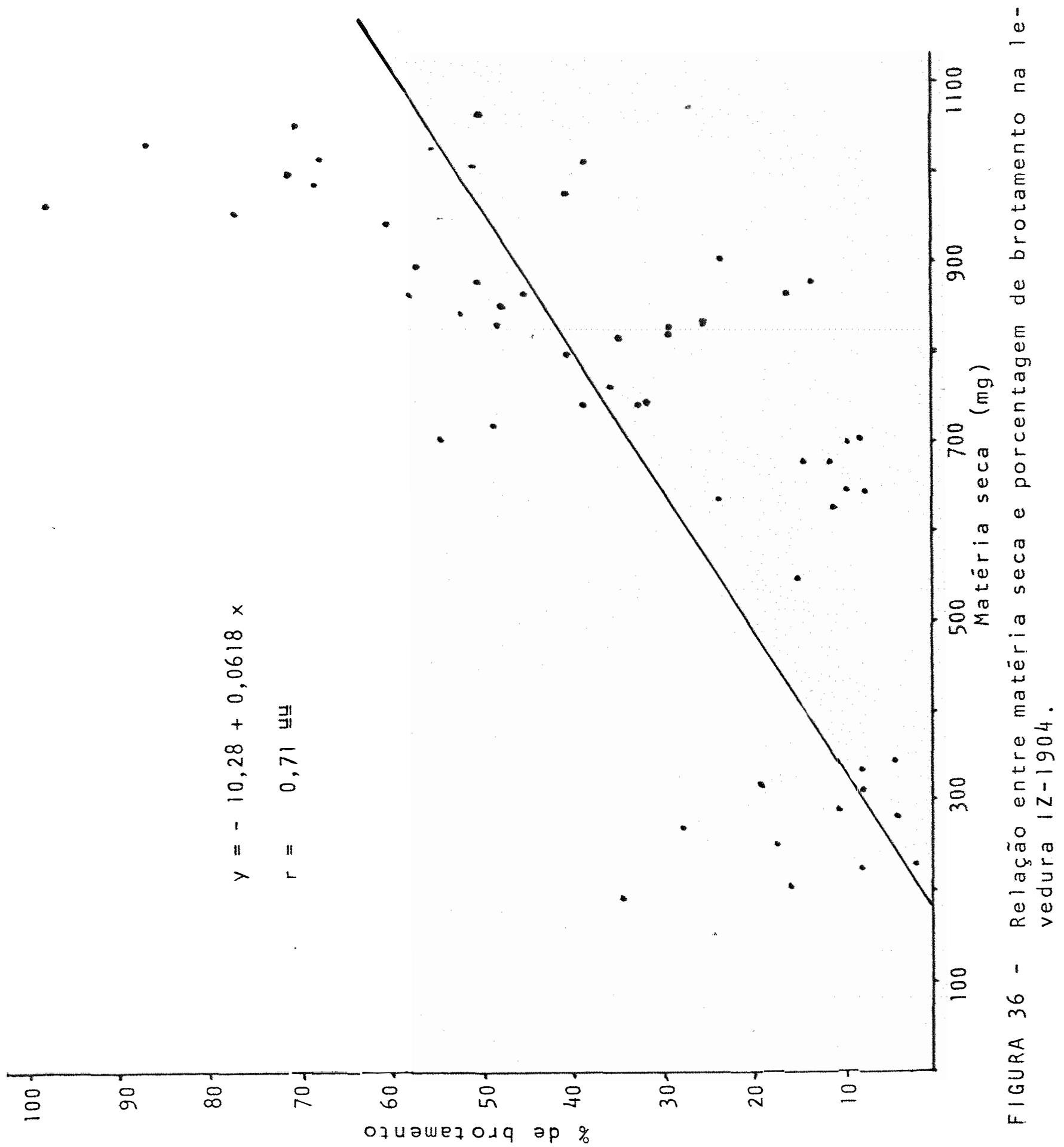




\section{5 - CONCUSÕES}

Os resultados obtidos permitem apresentar as conclusões seguintes.

o nitrogènio foi o elemento que mais afetou a produção de matēria seca das leveduras Fleischmann, 1Z-1904 e M-300-A, tanto em mosto de xarope quanto no de melaço. Es se efeito foi mais acentuado na segunda multiplicação que foi inoculada com levedura já deficiente da primeira multiplica. ६ão.

Em mosto de melaço ficou evidente que a levedu ra Fleischmann è mais exigente em nitrogènio seguida pela M-300-A e depois 1Z-1904. Tambēm ficou evidenciado que quanto mais exigente em nitrogènio maior será a produção de matéria seca pela levedura, quando em meio completo em nutrientes. 
o fósforo também, quando em baixa concentração afeta a produção de matéria seca das leveduras, embora de uma forma menos drástica que o nitrogènio.

As leveduras Fleischmann e M-300-A foram mais exigentes em fósforo que a $12-1904$.

As exigências quanto a nitrogènio pela leveduras foram maiores em mosto de xarope que de melaço.

As concentraçōes médias de magnésio $(0,0167 \%)$, manganês $(2,62 \mathrm{ppm})$ e zinco $(3,47 \mathrm{ppm})$ já existentes nos mos tos parecem ser suficientes para a multiplicação, já que as doses acrescentadas não influenciaram na produção de matéría seca das très linhagens estudadas.

A quantidade de células em brotamento foi influenciada pela quantidade de nitrogènio no mosto. Quanto mais nitrogênio, mais intenso foi o brotamento.

A levedura Fleischmann, foi a que maior quant dade de matéria seca produziu seguida pela M-300-A e depois $12-1904$.

As leveduras multiplicadas em meio deficiente em fösforo acumularam menos nitrogènio e potássio, e menor a cumulo de fósforo no tratamento deficiente em nitrogênio.

As leveduras multiplicadas em mosto de xarope e melaço com menor teor de fósforo,apresentaram um menor teor de magnèsio. 
A levedura $12-1904$ è diferenté das Fleischmann e M-300-A na capacidade de acumular zinco. Nos tratamentos com menor teor de fósforo as leveduras acumularam uma maior quantidade de zinco.

A maior quantidade de matéria seca fol obtida, pela suplementação do mosto de xarope com 400 ppm de nitrogênio.

A suplementação do mosto com 75 ppm de fósforo em mosto de xarope jä foi suficiente para manter um crescimen to satisfatörio.

A supressão ou acréscimo dos elementos nos mo tos não influiram na viabilidade das leveduras.

Quanto maior a quantidade de matéria seca obti da, maior era a quantidade de células em brotamento. 


\section{6 - BIBLIOGRAFIA}

AMORIM, H. V., 1977. Introdução à bioquímica da fermentação alcoólica. PLANALSUCAR, Araras, $91 \mathrm{p}$.

AMORIM, H. V. ; A. J. OLIVEIRA e E. A. ZAGO, 1981. Novos mé todos para o controle de destilaria de álcool. Sociedade Brasileira de Microbiologia, São Paulo (no prelo).

AULD, D. S. ; J. ATSUYA ; C. CAMPINO e P. VALENZUElo, 1976. Yeast RNA polymerase 1: a eukaryotic zinemetalloenzyme. Biochemical and Biophysical Research Communications, New York, 69: 548-554.

CATANI, R. A. e A. D. JACINTHO, 1974. Avaliação dafertilidade do Solo. Métodos de anälises. Piracicaba, SP, “Livroceres, $61 \mathrm{p}$.

COLLINS, C. H. e P. M. LYNE, 1970. Microbiologicals Methods. Butterworths. London. 
CONWAY, E. J. e M. E. BEARY, 1958. Active transport of magnesium acrosso the yeast cell membrane. The Biochemical Journal, Liverpool, 69: 275-280.

CONWAY, E. J. e M. E. BEARY, 1962. A magnesium yeast and its properties. The Biochemical Journal, Liverpool, 84: 328333.

DEVEREUX, E. D. e E. W. TANNER, 1927. Observations on the growth of yeast in pure nutrient solutions. Journal of Bac teriology, Baltimore, 14: 317-333.

DI CARLO, E. J. ; A. S. SCHULTZ e D. K. MC MANUS, 1951. The assimilation of nucleic acid derivatives and related compounds by yeasts. Journal of Biological Chemistry, Balti more, 189: 151-175.

DOS ANJOS MAGALHÃES, M. M. ; M. L. R. VAIRO e W. BORZANI, 1980. Influēncia da adição de fonte de nitrogènio ao mosto no teor de proteína da levedura residual da fermentação alcōo lica de melaço de cana-de-açūcar. Revista Brasileira de Tecnologia, São Paulo, 11: 13-21.

DUBOIS, E., 1975. Regulation genetrope des enzymes du cata bolisme de l'arginine chez Saccharomyces cerevisiae. Revue des fermentations et des Industries Alimentaires, 30 (6): $147-160$.

EVANS, H. J.e G. J. SORGER, 1966. Role of mineral elements with emphasis on univalent cátions. Annual Review of Plant Physiology, Palo Alto, 17: 47-77.

FALCONE, M. e M. R. ARRUDA, 1964. Estudo sobre obtenção de "pé-de-cuba" para produção de etanol a partir de mosto de melaço. São Paulo. Escola Politécnica - USP, Depto. de Engenharia Química. (Boletim 19), 29 p. 
FARAH ALVES, T. C. e V. DEL BIANCO, 1971. Produção de levedura alimento e assimilação do nitrogênio em melaços bras I leiros. Rio de Janeiro, $G B$, Publicaça do Instituto Nacional de Tecnologia, 45-63.

FEDOROVA, J. Y. ; S. E. TRAUBENBERG; 1 . A. POPADICH; 1 . F. GRIBOVSKAYA; N. N. MARHOVA E.L.V. SHEVYAKOVA, 1978. MI neral composition of Baker's yeast. Khlebopekarnaya $i$ Kon ditershaya Promyshlennost, Moskva (1): $34-5$ (Russian). Apud: Chemical Abstracts, Columbus, 88(19): 134, 1978 . (Ref. 839).

FREY, S. W. ; W. G. DE VITT e B. R. BELLOMY, 1967. Effect of several trace metals on fermentation. Proceedings of the American Society of Brewing Chemists, Chicago, 12: $199-205$.

FULMER, E. I. ; E. V. NELSON e F. F. SHERWOOD, 1921. The nu tritional requirements of yeast. 11 . The effect of the composition of the medium on the growth of yeast. Journal of the American Chemical Society, Easton, Pa., 43: 191199.

FULMER, E. I. ; L. A. UNDERKOFLER e J.B. LESH, 1936. Effect of the composition of the medium upon the growth of yeast in the presence of bios preparations. The effect of magne sium salts. Journal of the American Chemical Society, Easton, Pa., 58: 1356-1358.

GOODMAN, J. E A. ROTHSTEIN, 1957. The active transport of phosphate into the yeast cell. Journal of General Physiology, Baltimore, 40: 915 . 
HAROLO, F. M., 1966. Inorganic polyphosphates in biology; structure, metabolism and function. Bacteriological Reviews, Baltimore, 30: 772-794.

HERNANDEZ, M. R., 1960. Nuevas pruebas en torno a la ferme $\underline{n}$ tación de mostos submetidos a bajas pressiones. $8 \mathrm{p}$. Separata de la Semana Vitinicola. Madrid, Estación de Viticultura y Enologia de Haro.

HEWITT, E. J., 1963. The essencial nutrient elements: requiriments and interaction in plants. In: STEWARD, F. C. Plant Physiology, 111 . Inorganic nutrition of plants. New York, Academic Press, $811 \mathrm{p}$.

INDGE, K. J., 1968. Polyphosphates of tye yeast cell vacuole. Journal General Microbiology, Cambridge, 51: 447455 .

JENNINGS, D. H. ; D. C. HOOPER E A. ROTHSTEIN, 1958. The par ticipation of phosphate in the formation of a "carrier" the transport of $\mathrm{Mg}^{++}$and $\mathrm{Mn}^{++}$ions into yeast cells. Journal of General Physiology, Baltimore, $41(5)$ : 1019-1026.

LAWFORD, H. G. e J.R. PIK, 1980.a. Physiology of Candida utilis yeat in zinc-limited chemostat culture. Canadian Journal of Microbiology, Ottawa, 26: 64-70.

LAWFORD, H. G. e J.R. PIK, 1980.b. Hyperaccumulation of zinc by zinc-depleted Candida utizis grown in chemostat culture. Canadian Journal of Microbiology, Ottawa, 26: $71-76$. 
LAWFORD, H. G. ; J.R. PIK; G.R. LAWFORD; T. WILLIANS e A. KLIGERMAN, 1980. Hyper accumulation of zinc by zinc-depleted Candida utizis growth in chemostat culture. Canadian. Journal of Microbiology, ottawa, 26: 71-76.

LEGGETT, J.E., 1961. Entry of phosphate into yeast all. Plant Physiology, Lancaster, $\underline{36}(3): 277-284$.

LESH, J.B. ; L. A. UNDERKOFLER e E. I. FULMER, 1938. The effect of the composition of the medium upon the growth of yeast in the presence of bios preparations. 1 - The res ponse of several strains of saccharomyces cerevisiae. Journal of the American Chemical Society, Easton, Pa., 60 (2): $2505-2507$.

LIMA, U. A., 1953. Contribuição ao estudo da influéncia do manganês sobre o crescimento e atividades da Saccharomyces cerevisaie (Hansen), Piracicaba, SP., ESALQ/USP. 36 . (Tese de Doutoramento)

LING, R. S. e R. C. HOSENEY, 1977. Effect of certain nutrients on the gas produced in pre ferments. Cereal Che mistry, St. Paul, Minn., 54(3): 597-604.

MC HARGUE, S. S. e.R. K. CALFEE, 1931. Effect of manganese. copper and zinc on the growth of yeast. Plant Physiology, Lancaster, 6: 559-566.

MALAVOLTA, E. e 0. E. LOPEZ GOROSTIAGA, 1974. Studies on the zinc phosphate relationships in plant. In: Proceedings of the VII International Colloquium on Plant Analysis and Fertilizer Problems, Hannover, p. 261-272. 
MASSART, L. e J. HORENS, 1952. L'assimilation d'azote aminé par les lévures. Enzymologia, Acta Biocatalytica, Den Haag, $3(15): 359-361$.

MAYNARD, D. N. ; A. V. BARKER e W. H. LACHMAN, 1968. Influence of potassium on the utilization of amonium by tomato plants. Proceedings of the American Society Horticultural Science, College Park, 92: 543-552.

MORRIS, E. 0., 1958. The Chemistry and Biology of Yeasts. New York, Academic Press, N. Y.

MOTSARA, M. R., 1974. Micronutrient research in India. The identification and understanding of the problem with parti cular reference to zinc deficiency. In: Isotope-aided Mi cronutrient Studies in Rice Production with Special Referen ce to Zinc Deficiency. Vienna, FAO/IAEA, p. 61-74.

NORDHEIN, W., 1969. Specific relations and correlations in metabolism of yeast alls. Antonie van Leeuwenhoek. Yeast Symposium, Amsterdam, 35: 4-9. Suplemento.

OKOROKOV, L. A. ; L. P. LICHKO ; V. P. KHOLODEWKO ; V. M. KADONTSEVA ; S. B. PETRIKEVICH ;E. I. ZAICHKIN E A. M. KARI MOVA, 1975. Free and bound magnesium in fungi and yeast. Folia Microbilögica, Praque, 20(6): 460-466. Apud: Che mical Abstracts, Columbus, 85: 1976. (Ref. 156199 n).

OLIVEIRA, J. S. e M. F. SOUSA, 1970. Quelques aspects du me tabolisme minérale dans la levure Candida utizis. Revista. de Cièncias Agronômicas, Série A, Lourenço Marques, $\underline{3}$ : $33-66$. 
OLSON, H. e M. S. JOHNSON, 1949. Factors producing high yeast yields in synthetic media. Journal of Bacteriology, Baltimore, 57: 235-246.

ORTH, R. A. e W. BUSHUK, 1973. Studies of gentenin. 111 . Identification of subunits coded by the D-genome e their relation to bread making quality. Cereal Chemistry, St. Paul, 50: 680 .

PECIULIS, J.; E. AUGUSTAITTIENE; K. PAKARSKYTE e J. VALAVI CIUS, 1969. The role of micro elements on the acumulation of proteins and some vitamins in yeast cells. Antonie van Leeuwenhoek. Yeast Symposium. Amsterdam, 35: p. 13 . Suplemento.

PECIULIS, J., 1973. Physiologics biochemical activity of yeasts grown with trace elements. Itogi. Issled. Fziol. Biolkim.Rast., 1966-1970. gy. 1971. (Publ.1972), 14857. (Russ). Edited by Terentiev, V. M. Nauka i. Tekhnika; Minsk USSR. Apud: Chemical Abstracts, Columbus, 79 : 329, 1973. (Ref. $30.438 x)$.

PELCZAR, M. ; R. REID e E. C. S. CHAN, 1980. Microbiologia. São Paulo. Mc Graw-Hill do Brasil. v. I.

PIETZ, R. I. ; J.R. PETERSON ; C. LUE HING e L. F. WELCH, 1978. Variability in the concentration of twelve elements in rain: Journal of Environmental Quality, $7(1)$ : 106-110.

POPENKO, A. K. e Ya. K. BAYAKHUMOV, 1971. Effect of some trace elements on microorganisms. Izv. Akad. Nank. Kaz. SSR, Ser.Biol., 1971. $9(2): 33-38$ (Russ). Chemical. Abstracts, Columbus, 75: 101, 1971 (Ref. $45.928 \mathrm{y}$ ). 
REED, G. e H. J. PEPPLER, 1973. Yeast Technology. Westport, Connecticut, The Avi Publishing.

SALGADO, J. M. e J.R. SARRUGE, 1979. Influéncia dos compostos nitrogenados e da relação C/N na obtenção do concen trado protéico de microrganismos. Revista Microbiológica, São Paulo, 10(1): 15-17.

SARRUGE, J.R. e H. P. HAAG, 1974. Anälise Química em Plan. tas. Piracicaba, SP. ESALQ/USP. Departamento de Química. $56 \mathrm{p}$.

SCHULTZ, A. S. e S. POMPER, 1948. Amino acids as nitrogen source for the growth of yeasts. Archives of Biochemistry, New York, 19: 184-192.

STEVENINK, J. Van e H. L. BoOIS, 1964. The role of polyphos phates in the transport mechanism of glucose in yeast cells. Journal of General Physiology, Baltimore, 48: 43-60.

STEVENINK, J. van 'e A. ROTHSTEIN, 1965. Sugar transport and metal binding in yeast. Journal of General Physiology, Bal timore, 49: 235-246.

SUGATA, H. e F. C. KOCH, 1926. Sulphur metabolism of yeast. Plant Physiology, Lancaster, 1 : 337-347.

SUOMALAINEN, H. e E. OURA, 1971. Yeast nutrition and solute uptake. In: ROSE, A. A. e J. S. HARRISON. The Yeasts. 3. ed., London. Academic Press. v. 2, p. 3. 
THORNE, R. S. W., 1933. The ability of certain pure chemical compounds to function as nitrogen sources for yeast. Journal of the Institute of Brewing, London, 39: 608-621.

THORNE, R. S. W., 1941. The growth and fermentation of a strain of $S$. cerevisiae with amino acids as nutrients. Journal of the Institute of Brewing, London, 67: 259-272.

THORNE, R. S. W., 1949. Nitrogen metabolism of yeast, a consideration of the mode of assimilation of amino acids. Journal of the Institute of Brewing, London, 55: 201-222.

VAIRO, M. I.R. ; E. E. GREGORI e V. BORZANI, 1975. Respos tas de um cultivo continuo de saccharomyces cerevisiae a perturbaçōes por impulso provocadas por adição de sulfato de amónio. Revista Brasileira de Tecnologia, São Paulo, 6: $1-6$.

WANDZILAK, T.M. e R. W. BENSON, 1977. Yeast RNA polymerase. 111. A zinc metalloenzyme. Biochemical and Biophysi. cal Research Communications, New York, 76: 247-252.

WHITE, J., 1954. Yeast Technology. Chapman and Hall. Lon don, $432 \mathrm{P}$.

WHITNEY, P. A. e T. G. COOPER, 1970. Area carboxylase and allophanate hydrolase; two components of a multienzyme complex in Saccharomyces cerevisiae. Biochemical and Bio. physical Research Communications, New York, 40: 814-819.

WICKERHAM, L. J., 1946. A critical evaluation of the nitro gen assimilation tests commonly used in the classification of yeasts. Journal of Bacteriology, Baltimore, 52: 293301 . 
88.

$$
7-A P E N D I C E
$$


89.

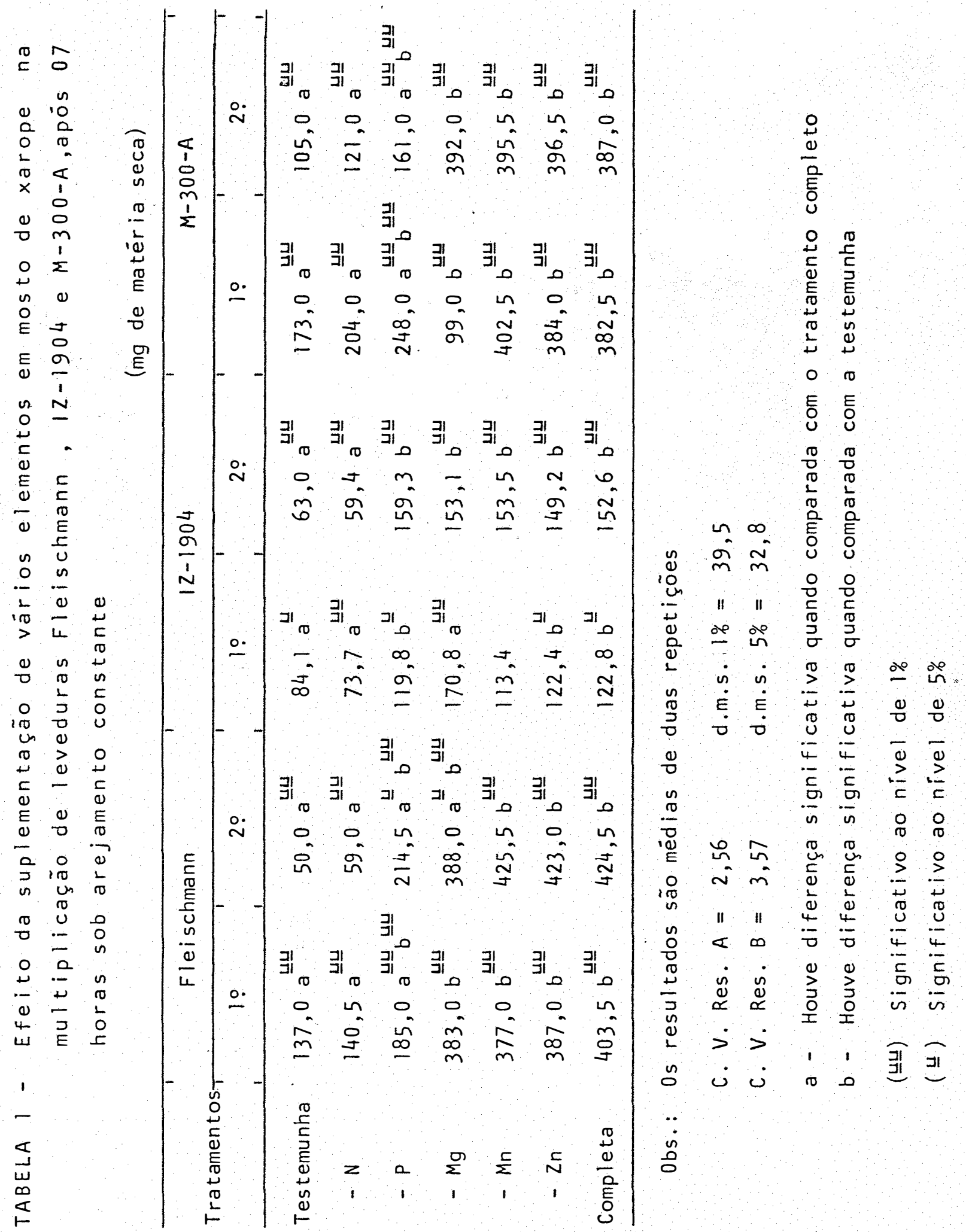




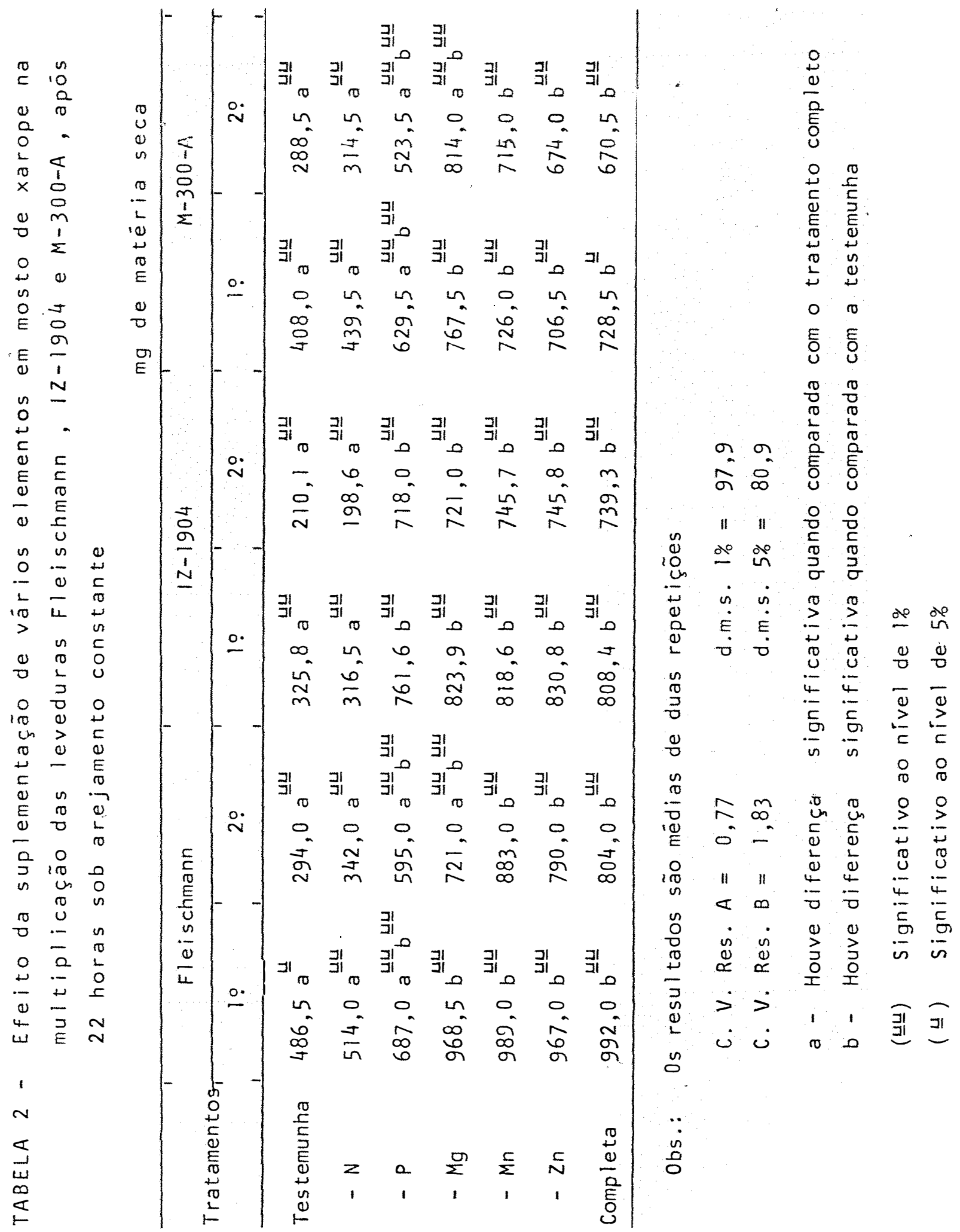


TABELA 3 - Porcentagem da viabilidade das células fleischmann, IZ-1904 e M-300-A, multiplicados em mosto de xarope suplementado com vários elementos

\begin{tabular}{|c|c|c|c|c|c|c|}
\hline \multirow{2}{*}{ Tratamento } & \multicolumn{2}{|c|}{ Fleischmann } & \multicolumn{2}{|c|}{$12-1904$} & \multicolumn{2}{|c|}{$M-300-A$} \\
\hline & 19 & 29 & 19 & $2 ?$ & 19 & 29 \\
\hline Testemunha & 77,0 & 88,7 & 89,5 & 98,0 & 100,0 & 100,0 \\
\hline$-N$ & 95,5 & $=91,2$ & 95,7 & 98,2 & 100,0 & 99,0 \\
\hline$-P$ & 94,5 & 62,7 & 91,2 & 94,0 & 98,3 & 100,0 \\
\hline$-M g$ & 91,0 & 79,4 & 90,4 & 93,2 & 93,3 & 100,0 \\
\hline$-M n$ & 82,5 & 85,5 & 92,2 & 93,0 & 89,3 & 97,6 \\
\hline$-2 n$ & 87,6 & 83,5 & 88,6 & 96,0 & 100,0 & 98,6 \\
\hline Completa & 80,0 & 86,0 & 88,2 & 94,2 & 100,0 & 100,0 \\
\hline
\end{tabular}


TABELA 4 - Porcentagem de brotamento em cëlulas de leveduras Fleischmann, 1Z-1904 e M-300-A, multiplicadas em mosto de xarope suplementados com vários elementos

\begin{tabular}{|c|c|c|c|c|c|c|}
\hline \multirow{2}{*}{ Tratamentos } & \multicolumn{2}{|c|}{ Fleischmann } & \multicolumn{2}{|c|}{$1 z-1904$} & \multicolumn{2}{|c|}{$M-300-A$} \\
\hline & 19 & $2:$ & 19 & 29 & 19 & $2 !$ \\
\hline Testemuntia & 2,8 & 5,3 & 19,7 & 15,9 & 15,0 & 12,8 \\
\hline$-N$ & 12,0 & 13,6 & 18,2 & 35,0 & 11,6 & 18,7 \\
\hline$-P$ & 17,3 & 29,6 & 35,4 & 54,5 & 15,8 & 38,0 \\
\hline$-M g$ & 35,8 & 49,6 & 29,4 & 49,0 & 47,7 & 43,0 \\
\hline$-M n$ & 27,5 & 48,4 & 34,7 & 39,2 & 40,4 & 45,3 \\
\hline$-Z n$ & 25,1 & 46,3 & 31,3 & 32,0 & 36,8 & 39,4 \\
\hline Completa & 28,1 & 47,6 & 40,2 & 33,3 & 53,2 & 32,7 \\
\hline
\end{tabular}


93.

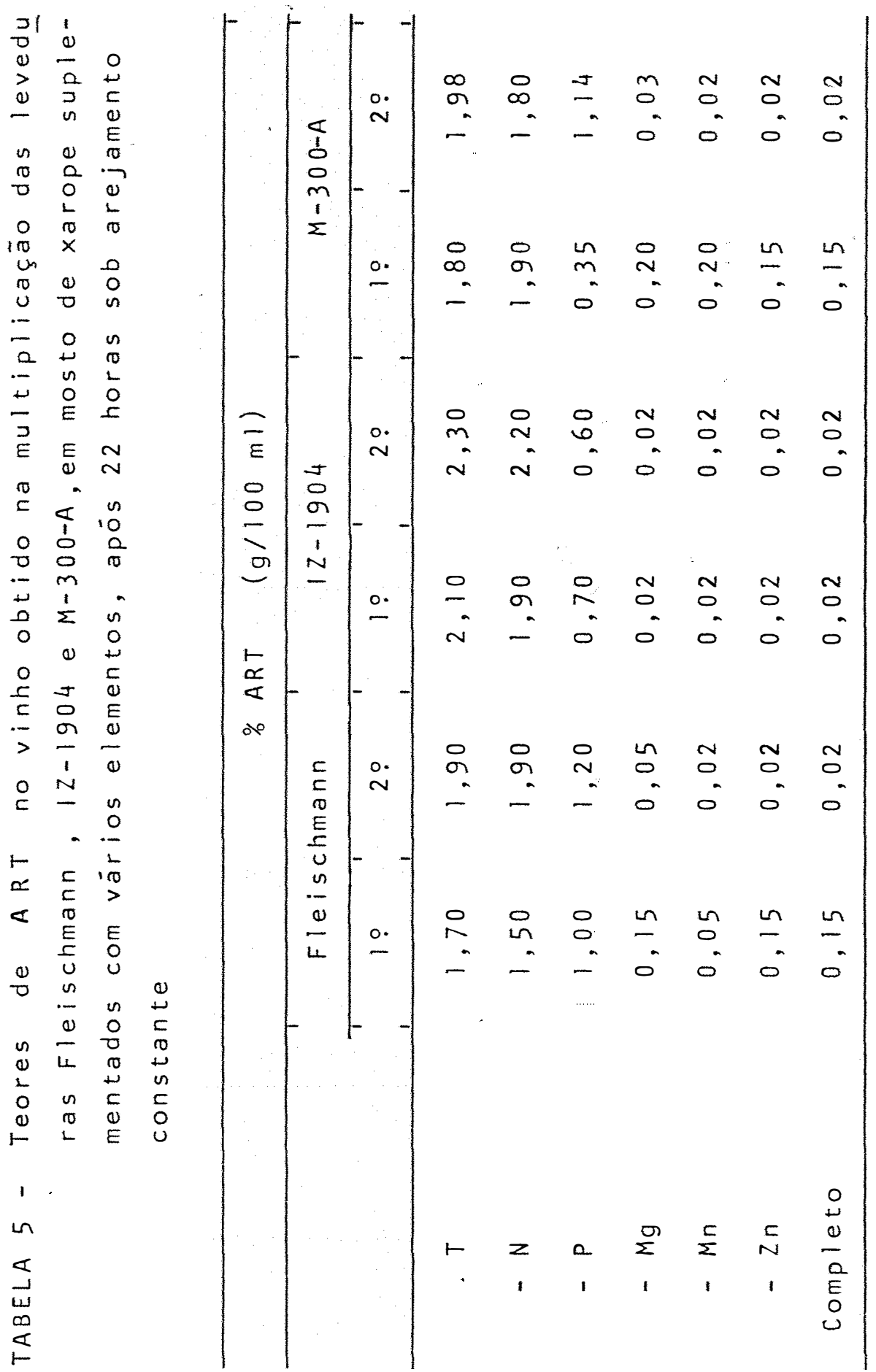




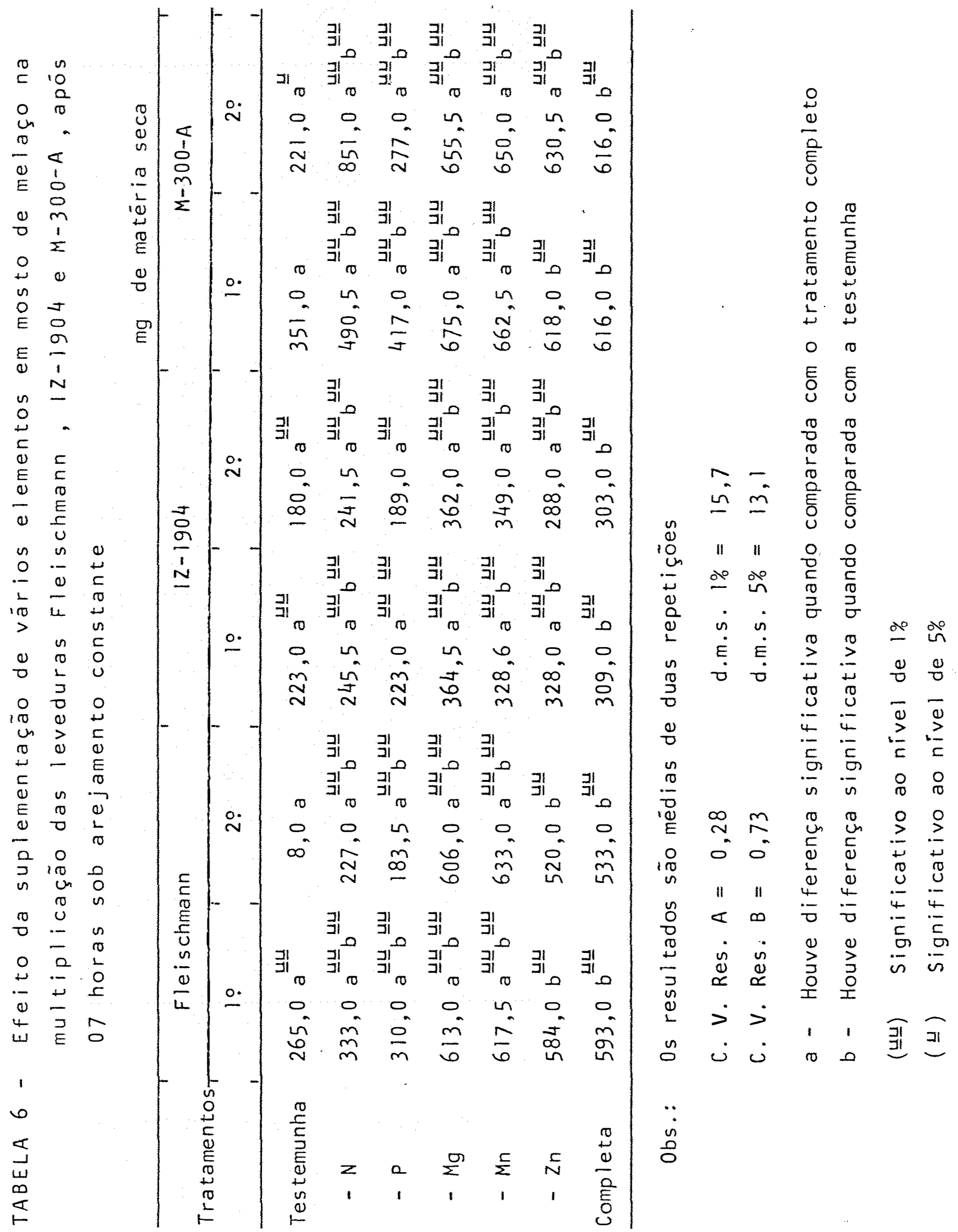




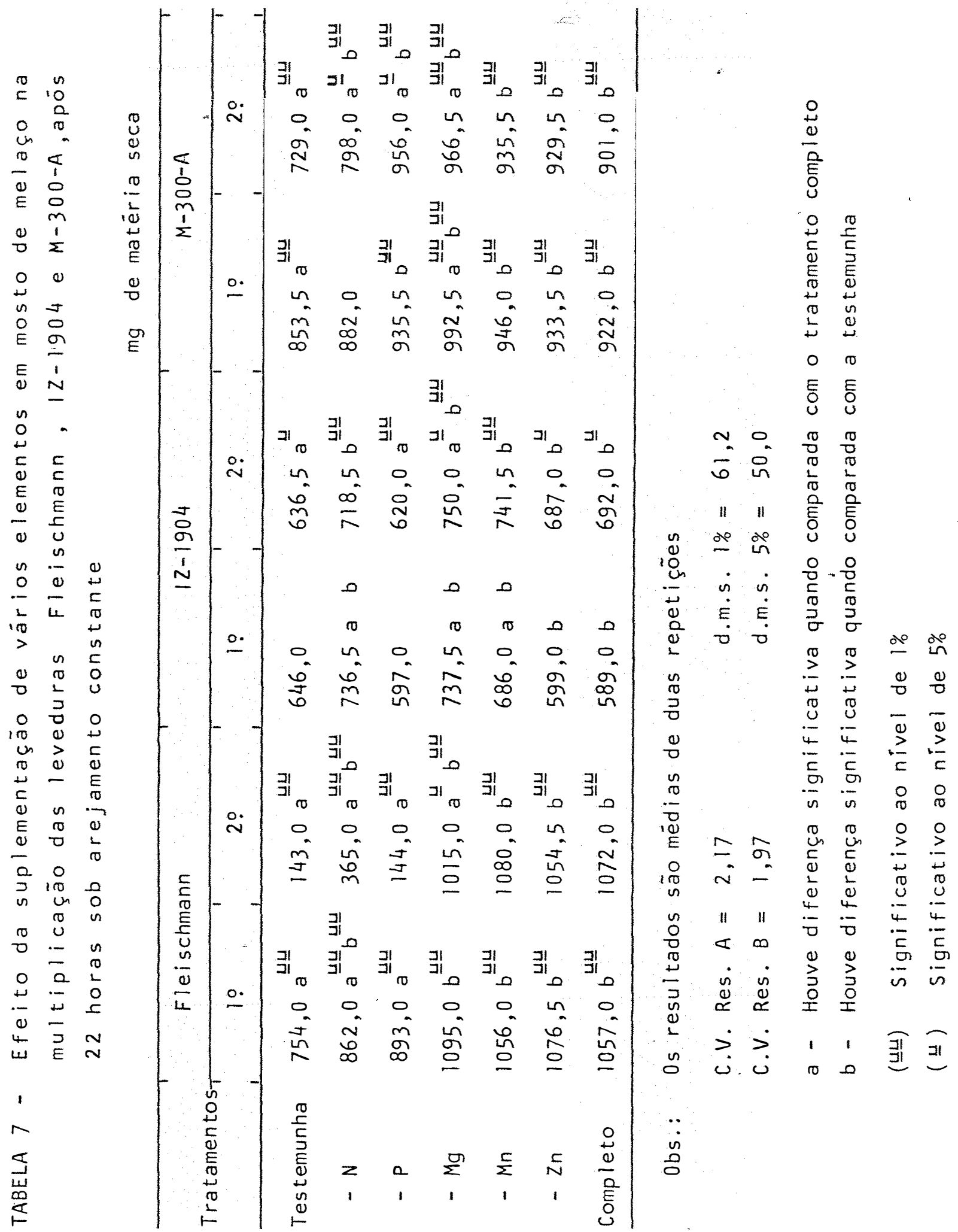


TABELA 8 - Porcentagem de viabilidade das células fleischmann, IZ-1904 e M-300-A multiplicada em mosto de melaço suplementados com vários elementos

\begin{tabular}{ccccccccc}
\hline \multirow{2}{*}{ Tratamento } & \multicolumn{2}{c}{ Fleischmann } & \multicolumn{1}{c}{ IZ-1904 } & \multicolumn{2}{c}{ M-300-A } \\
\cline { 2 - 6 } & 19 & 20 & 19 & 29 & 19 & 29 \\
\hline Testemunha & 94,2 & 100,0 & 99,4 & 99,5 & 99,4 & 98,3 \\
- N & 99,2 & 97,7 & 99,2 & 99,1 & 98,3 & 97,7 \\
- P & 80,3 & 98,5 & 99,2 & 97,4 & 97,5 & 98,6 \\
- Mg & 99,2 & 94,4 & 98,8 & 98,6 & 96,3 & 98,6 \\
- Mn & 80,4 & 95,5 & 96,6 & 99,4 & 95,5 & 98,7 \\
- Zn & 94,0 & 96,5 & 97,8 & 98,7 & 96,1 & 98,6 \\
Completa & 98,0 & 97,1 & 97,7 & 96,8 & 95,3 & 98,1 \\
\hline
\end{tabular}


TABELA 9 - Porcentagem de brotamento em células de leveduras Fleischmann, 1Z-1904 e M-300-A, multiplicada em mosto de melaço suplementado com vários elementos

\begin{tabular}{|c|c|c|c|c|c|c|}
\hline \multirow{2}{*}{ Tratamentos } & \multicolumn{2}{|c|}{ Fleischmann } & \multicolumn{2}{|c|}{$1 z-1904$} & \multicolumn{2}{|c|}{$M-300-A$} \\
\hline & 10 & $2 \%$ & 19 & $2 \circ$ & 10 & $2:$ \\
\hline Testemunha & 10,0 & 9,0 & 8,3 & 8,8 & 5,1 & 7,1 \\
\hline$-N$ & 6,2 & 8,5 & 8,6 & 24,3 & $=11,5$ & 9,2 \\
\hline$-P$ & 10,0 & 12,4 & 15,9 & 19,5 & 4,2 & 19,5 \\
\hline$-M g$ & 34,1 & 25,7 & 21,7 & 26,1 & 33,7 & 43,7 \\
\hline$-M n$ & 31,5 & 24,2 & 28,2 & 29,1 & 29,9 & 27,3 \\
\hline$-2 n$ & 18,7 & 21,6 & 33,7 & 28,5 & 21,5 & 44,6 \\
\hline Completa & 32,2 & 27,2 & 24,1 & 22,1 & 38,0 & 27,9 \\
\hline
\end{tabular}




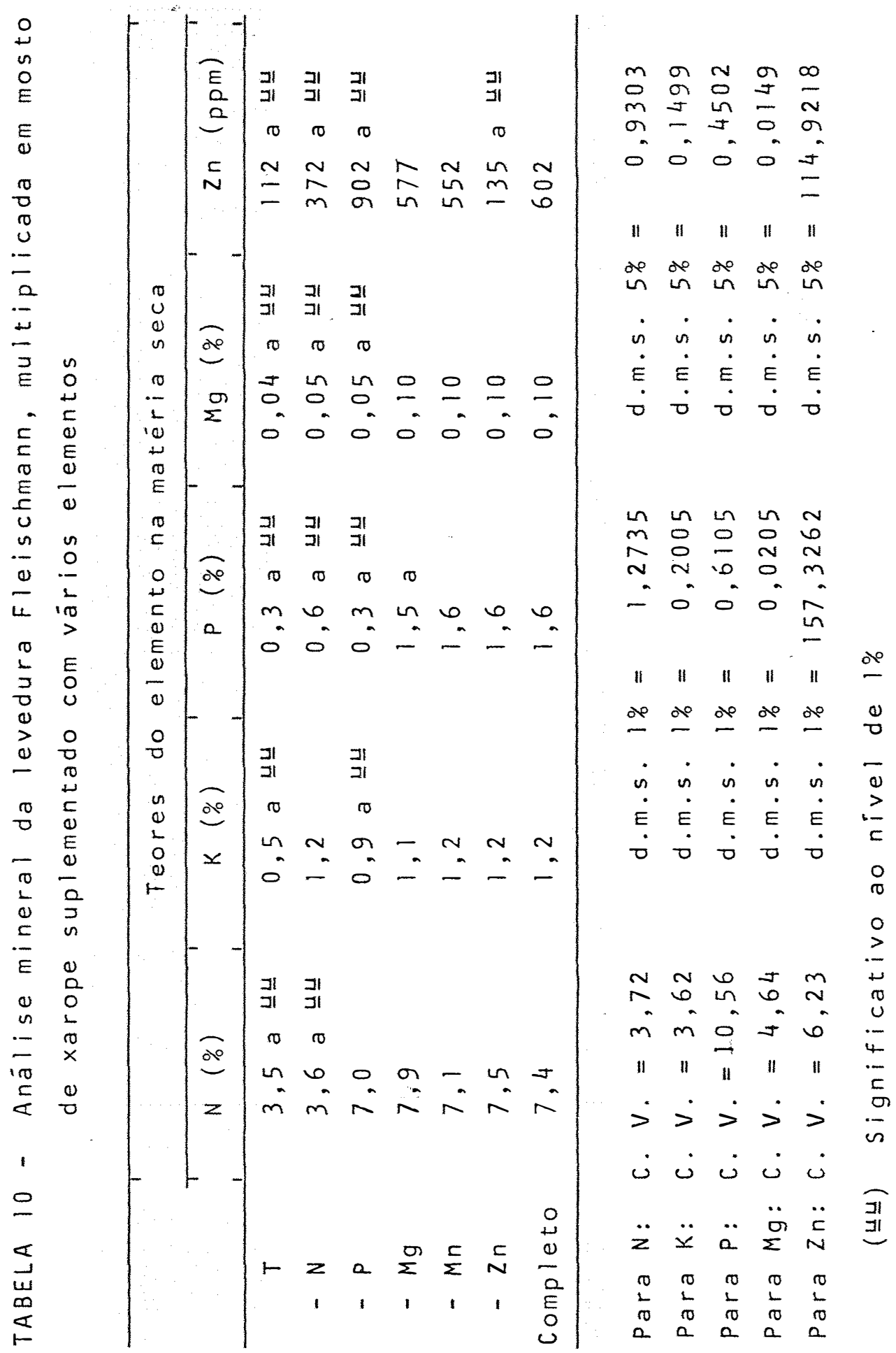




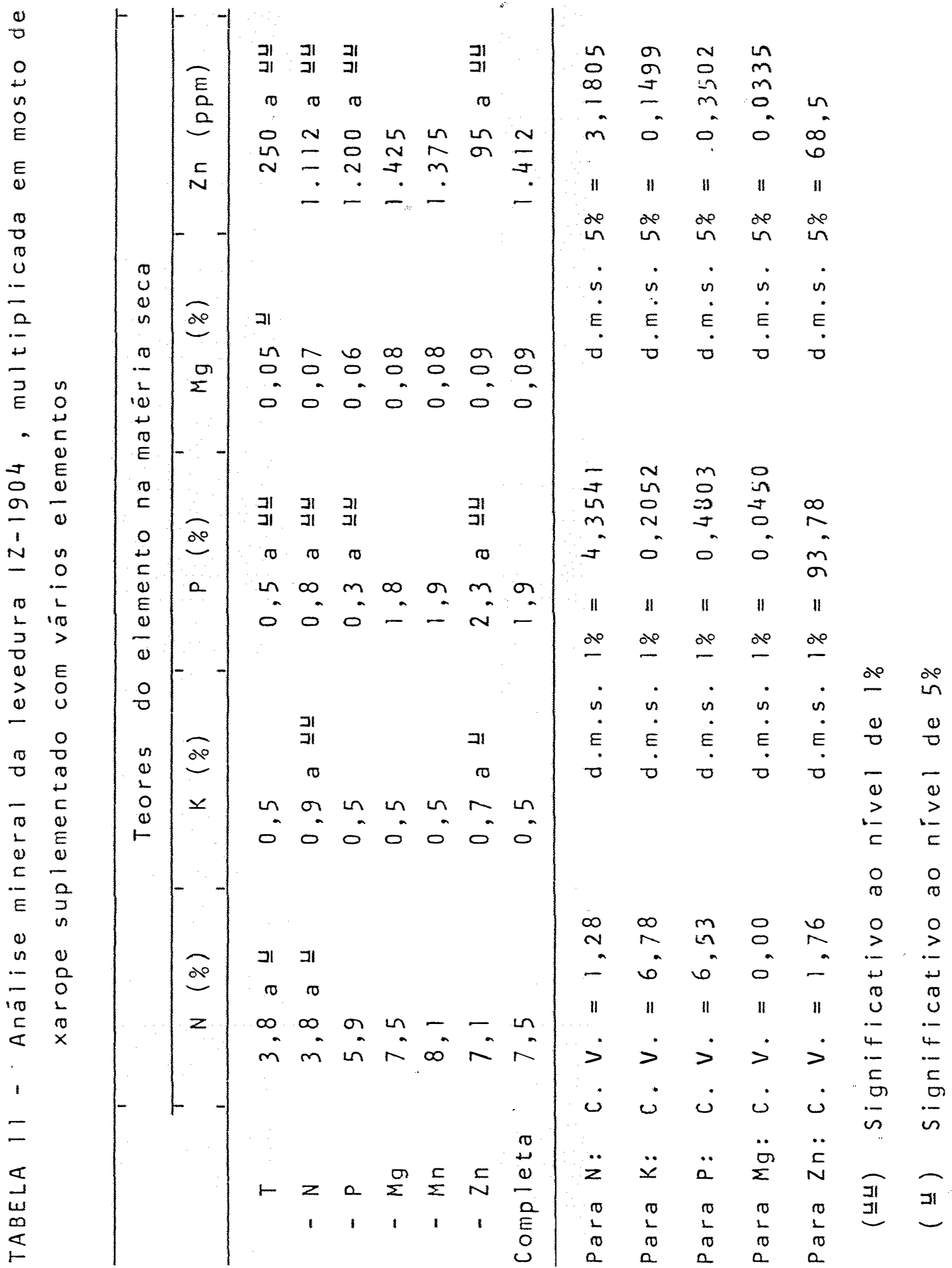




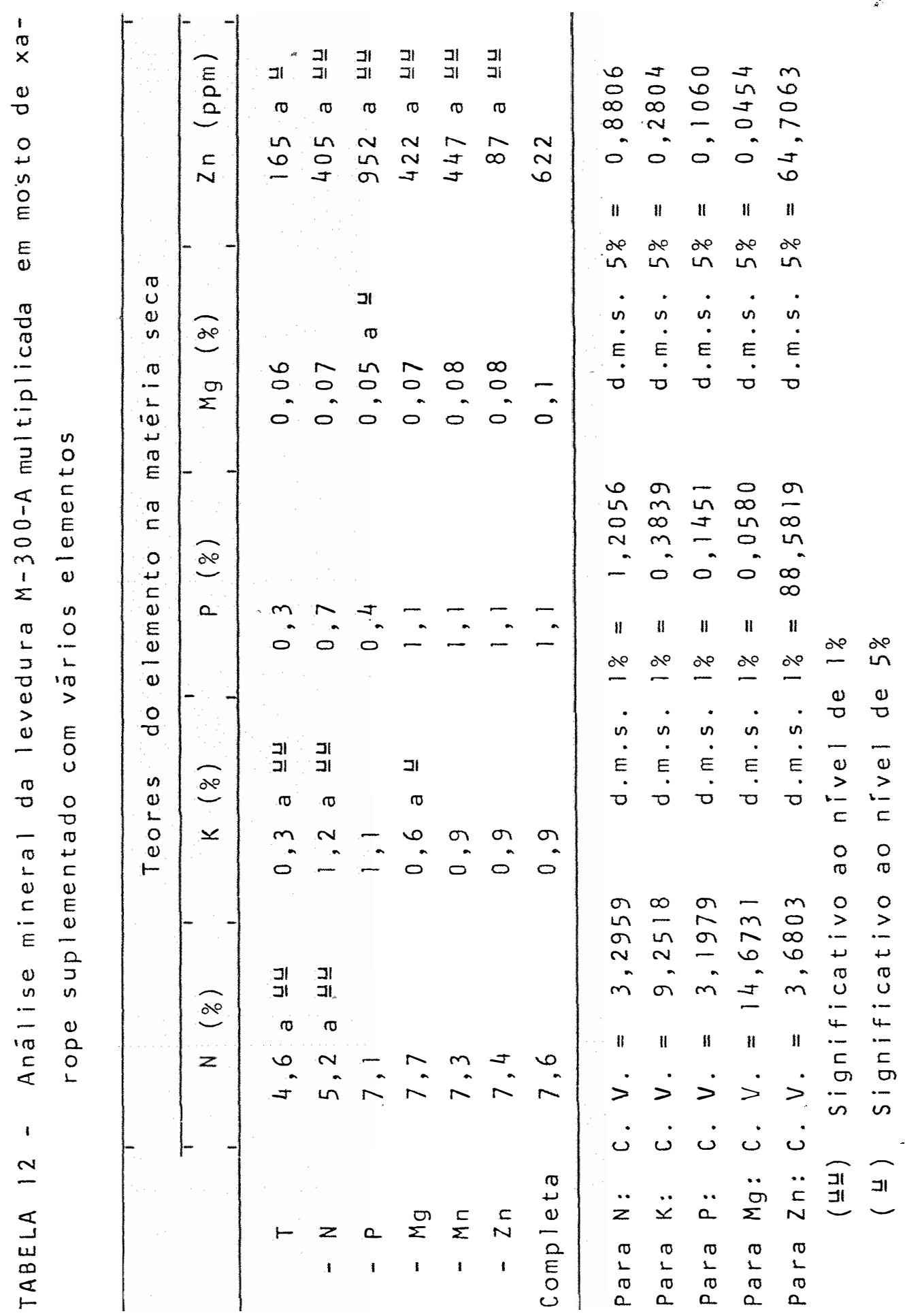




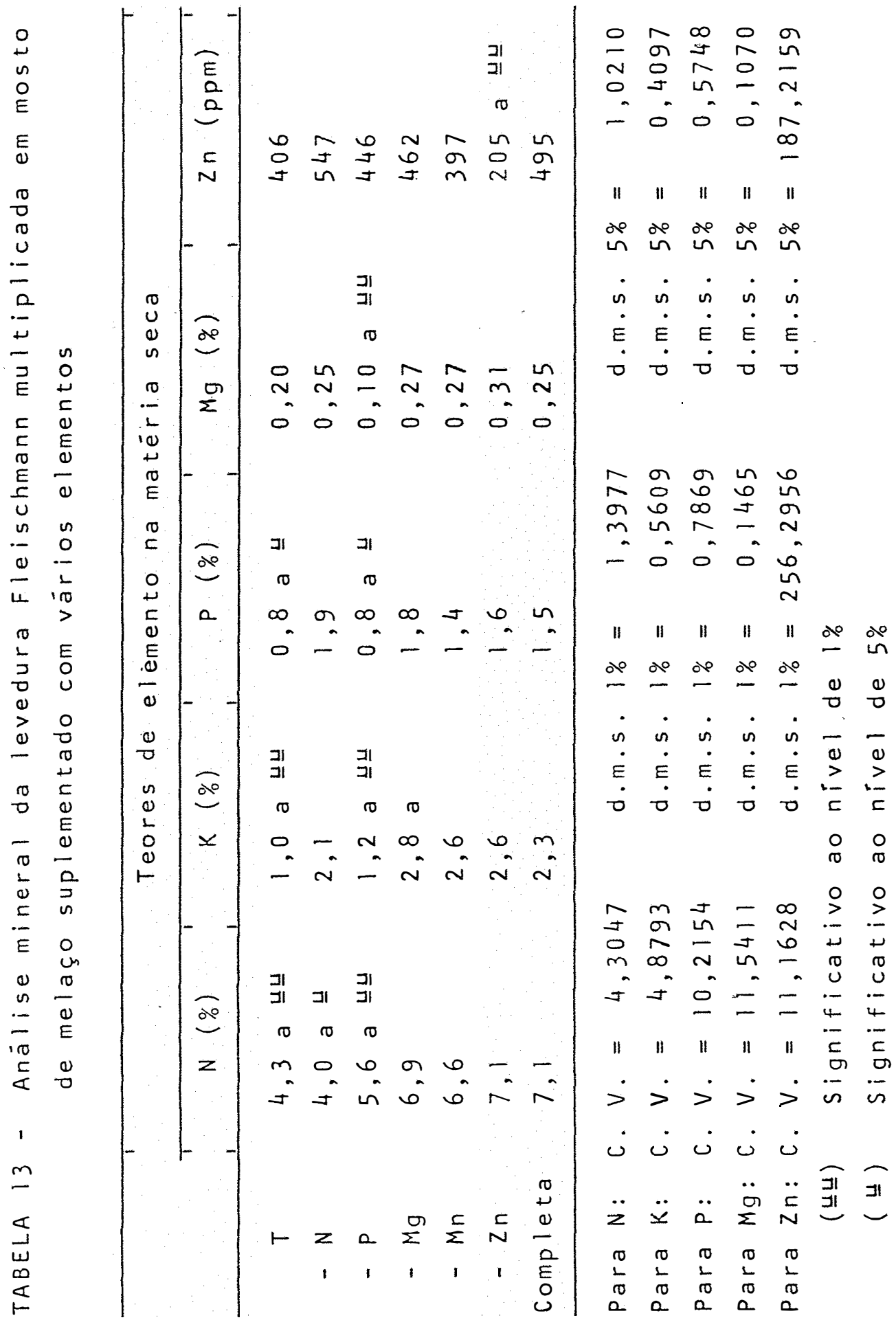




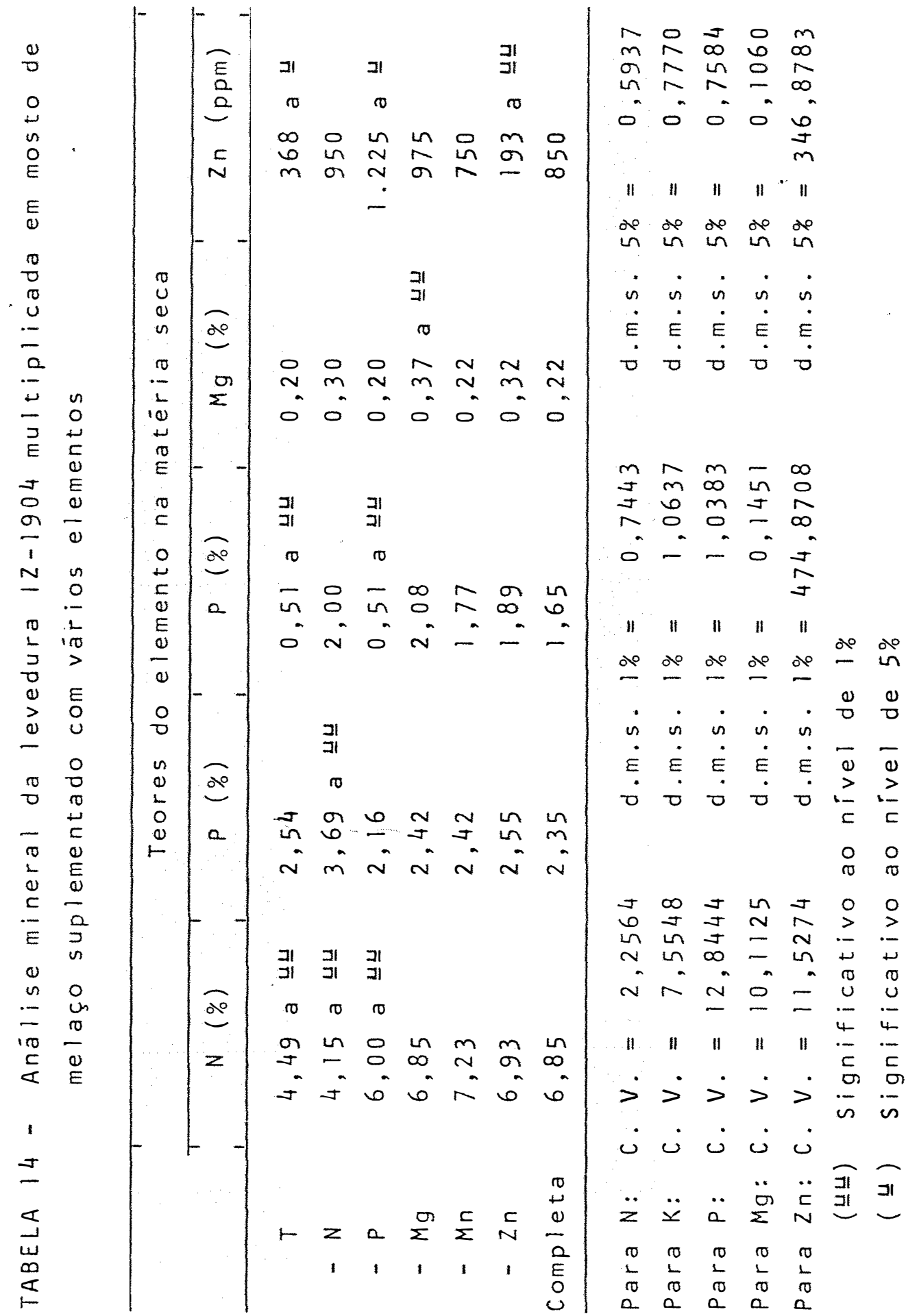




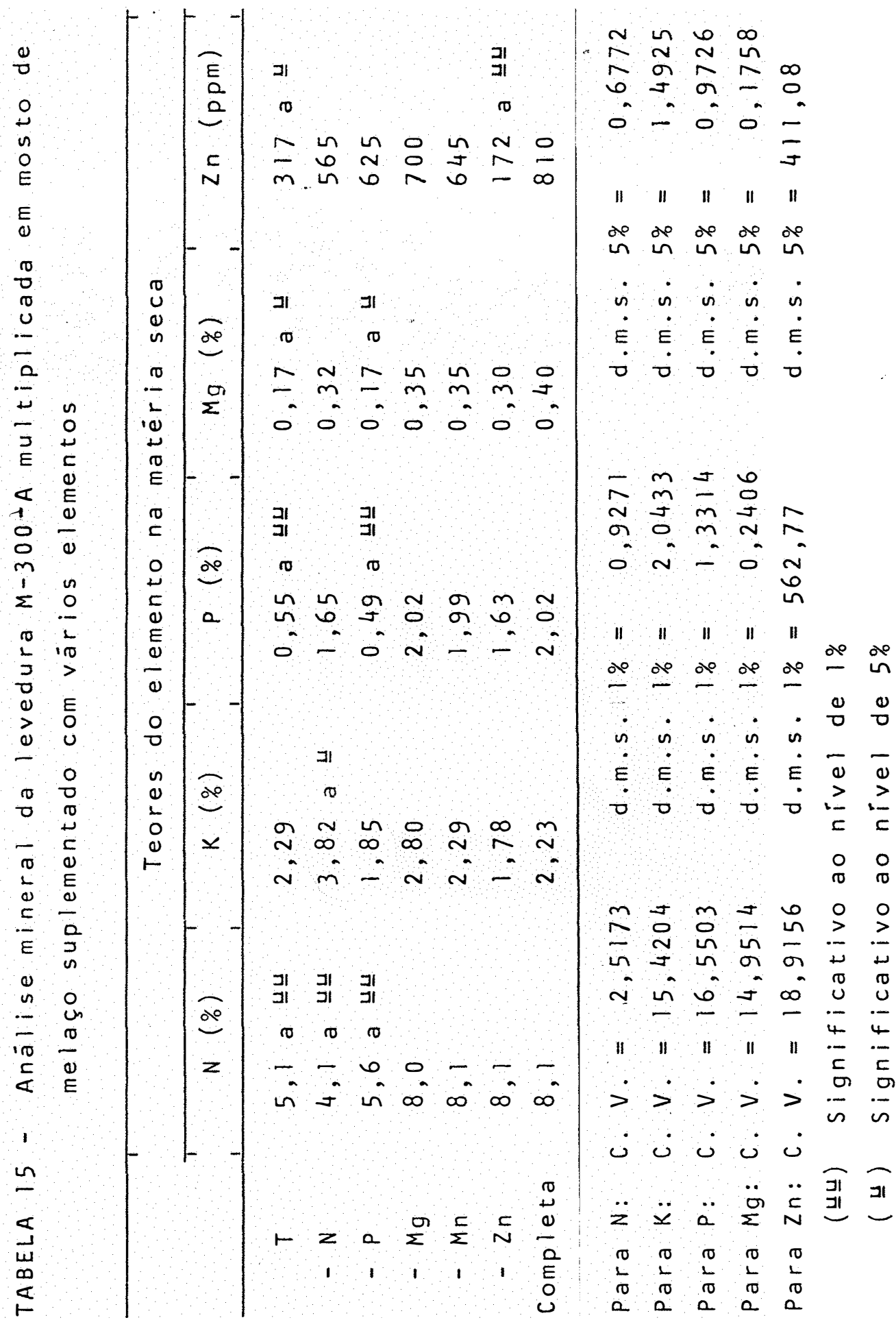


104.

$\begin{array}{ll}n & 0 \\ 0 & 1 \\ 4 & J \\ 5 & 0 \\ 0 & 0 \\ 1 & > \\ 0 & 0 \\ 4 & - \\ -0 & \end{array}$

$\begin{array}{ccc}E & & 0 \\ 0 & 0 & + \\ 0 & 0 & E \\ 0 & & 0 \\ 1 & & u \\ 0 & 0 & E \\ 4 & 0 & 0 \\ \text { un } & 10 & 0 \\ 0 & u & U\end{array}$

io un U

o U

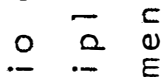

E I

ब1 0 ग

O E $\frac{1}{1}$

$\begin{array}{lll}1 & 0 & 0 \\ \mp & ᄃ\end{array}$

c 50

0 003

$\begin{array}{lll}0 & 1 & 1 \\ 10 & 0 & 0\end{array}$

in $x$ 工

$\stackrel{0}{0} 0$

E 010

$\begin{array}{ccc}E & 0 & 1 \\ 0 & 2 & 0 \\ - & 0 & 0\end{array}$

D $\quad O$.

$\begin{array}{lll}N & E & E \\ O & O & O \\ O & & E\end{array}$

- n

- -10

o $>0$

w

1
0
$\square$
$w$
0
$\leftarrow$

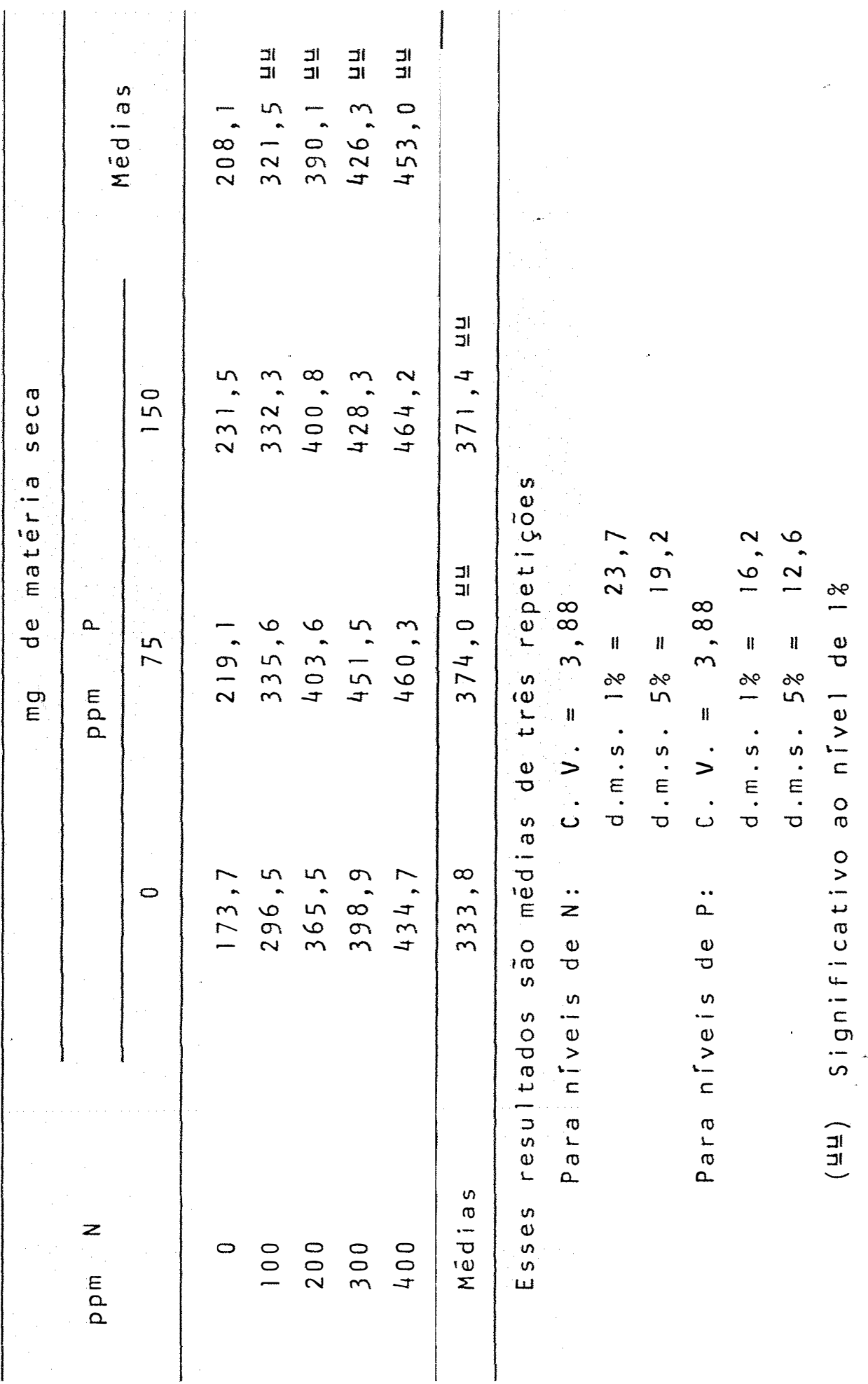




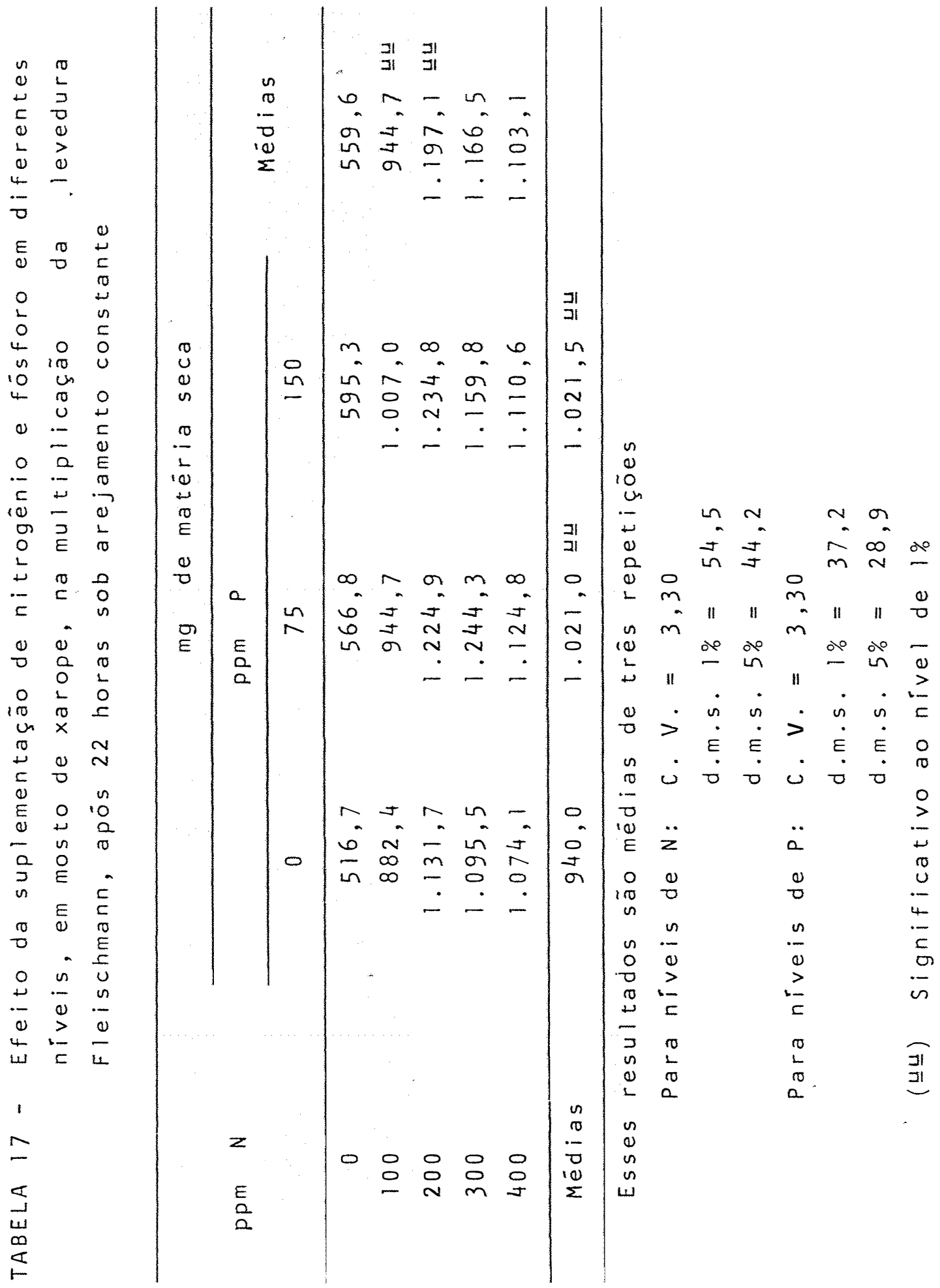




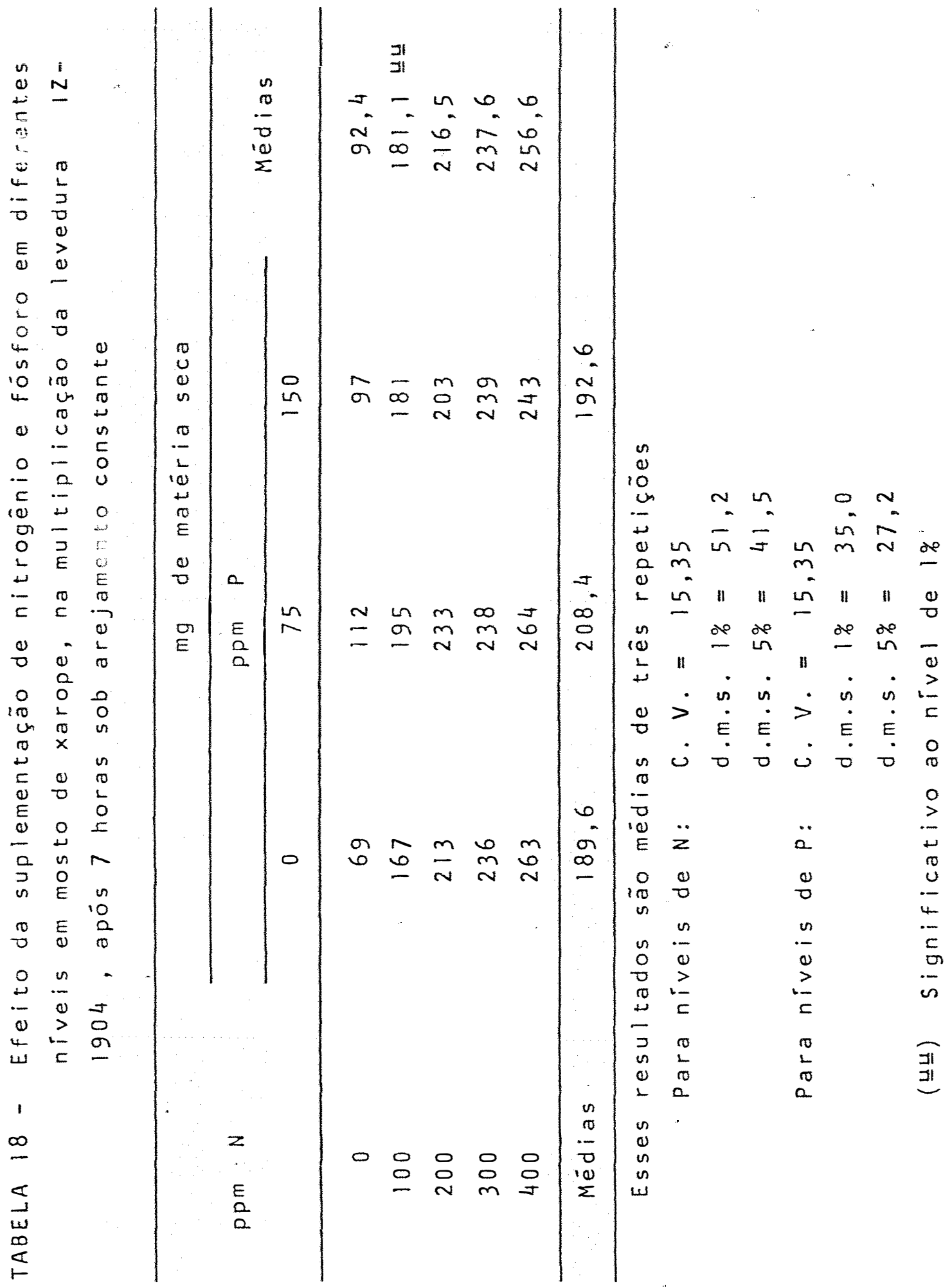


107.

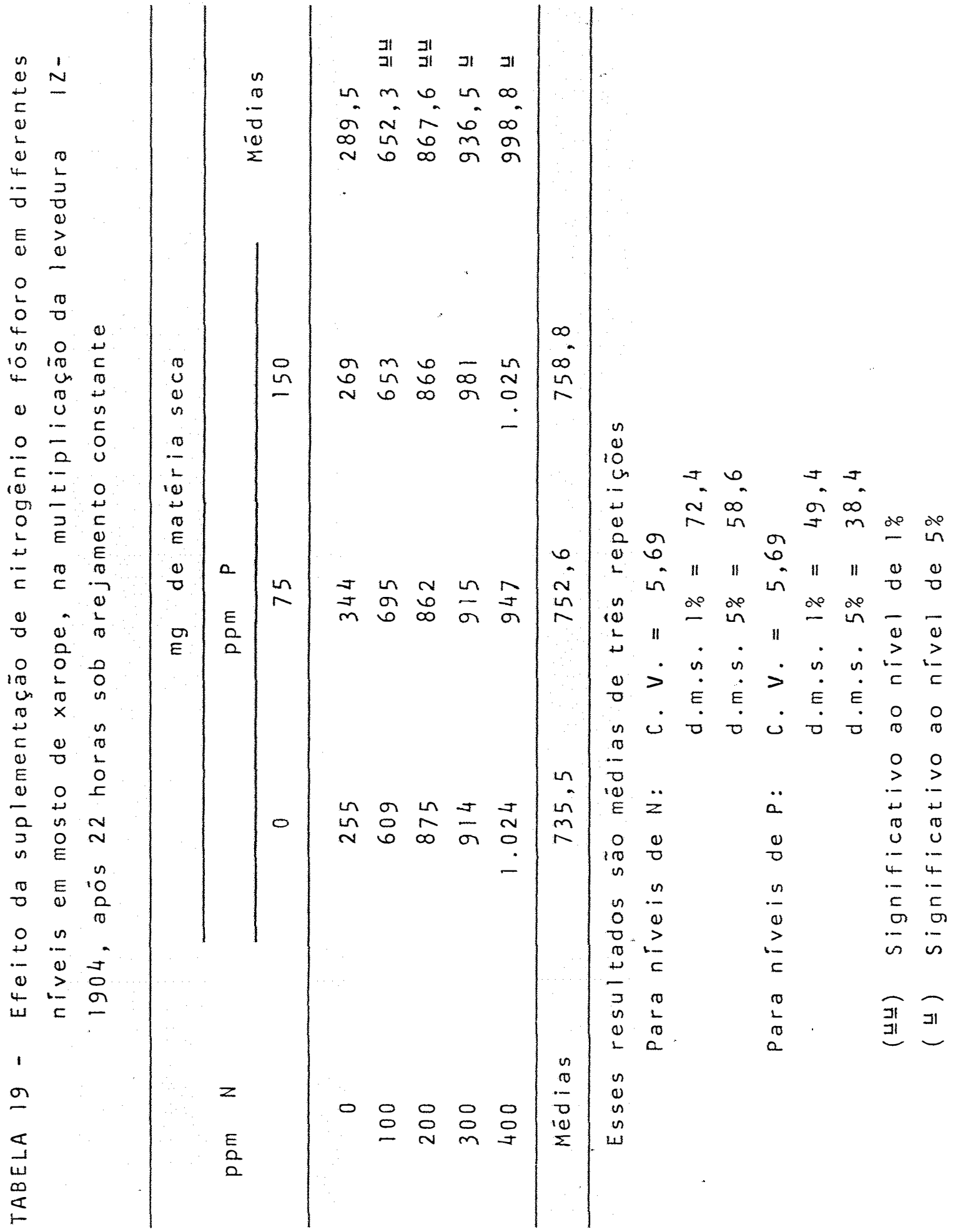




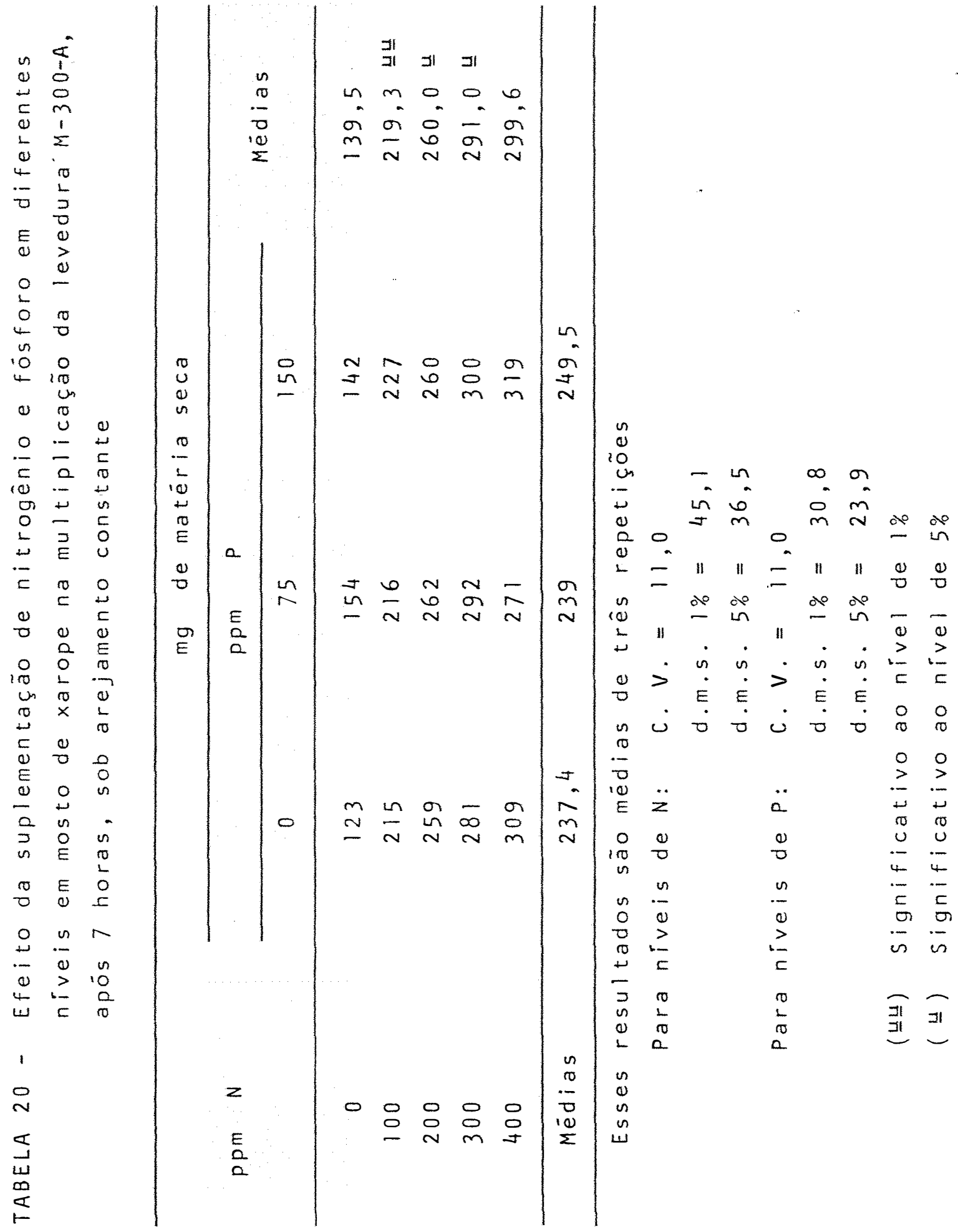




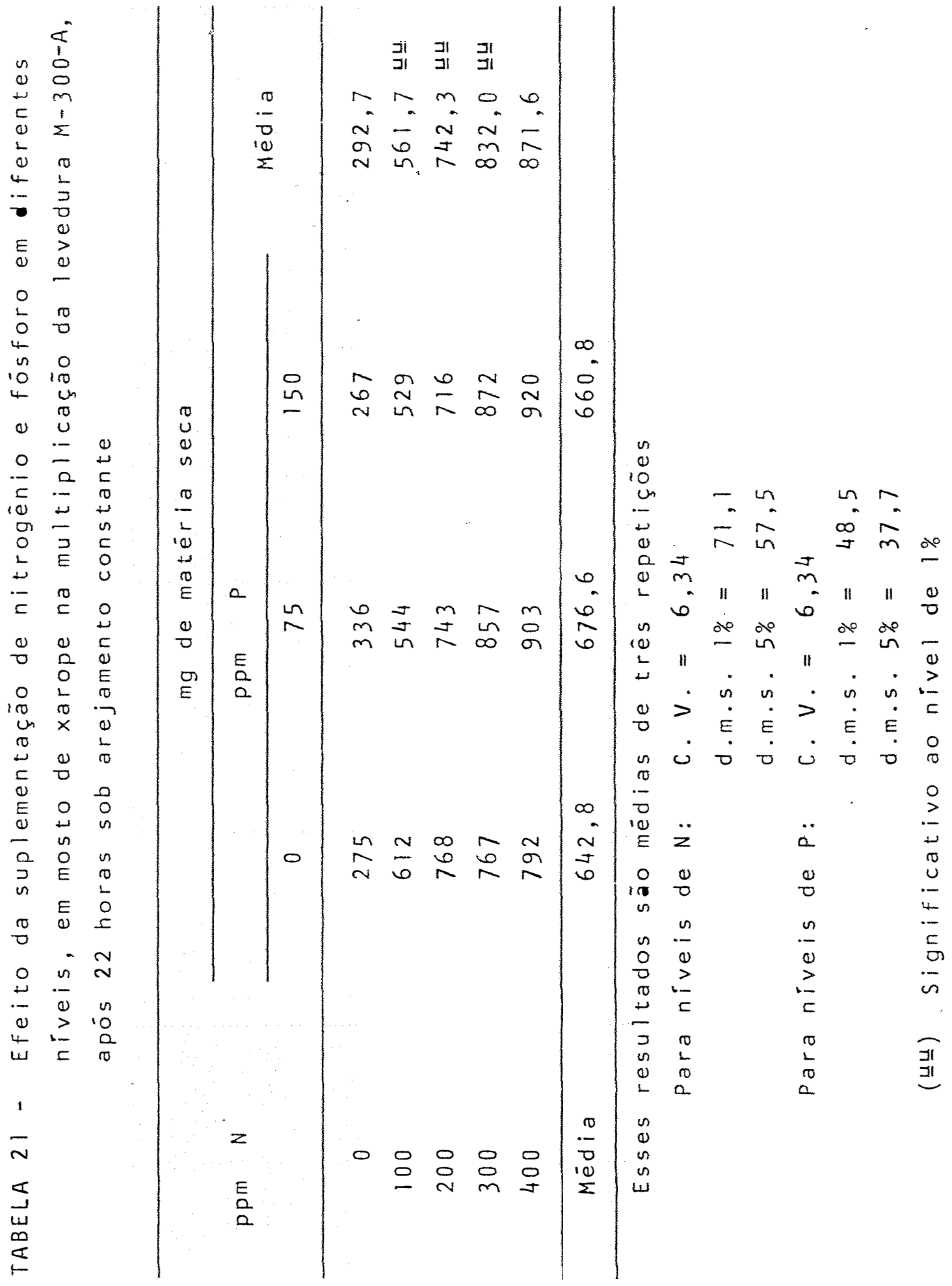


110.

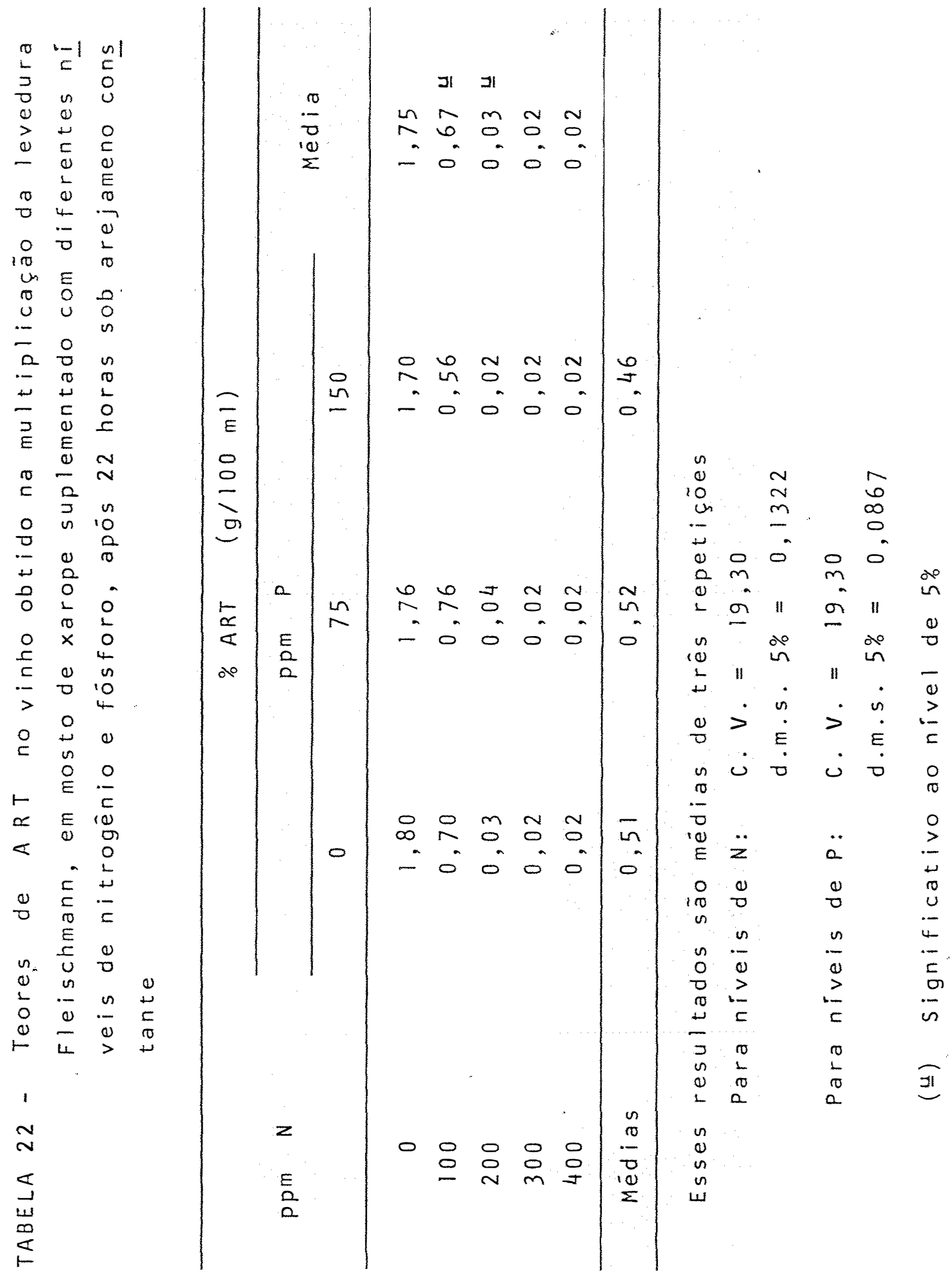




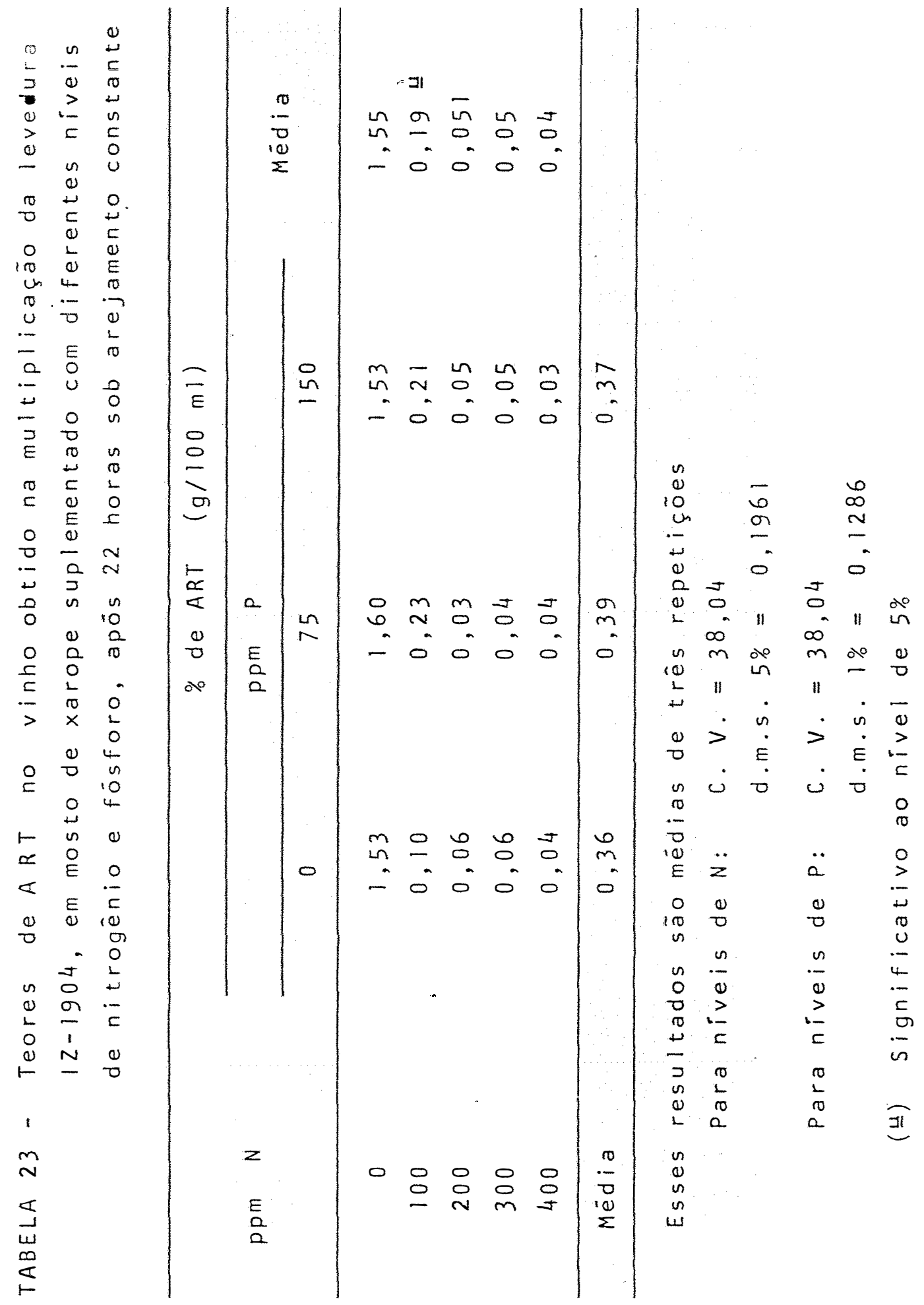




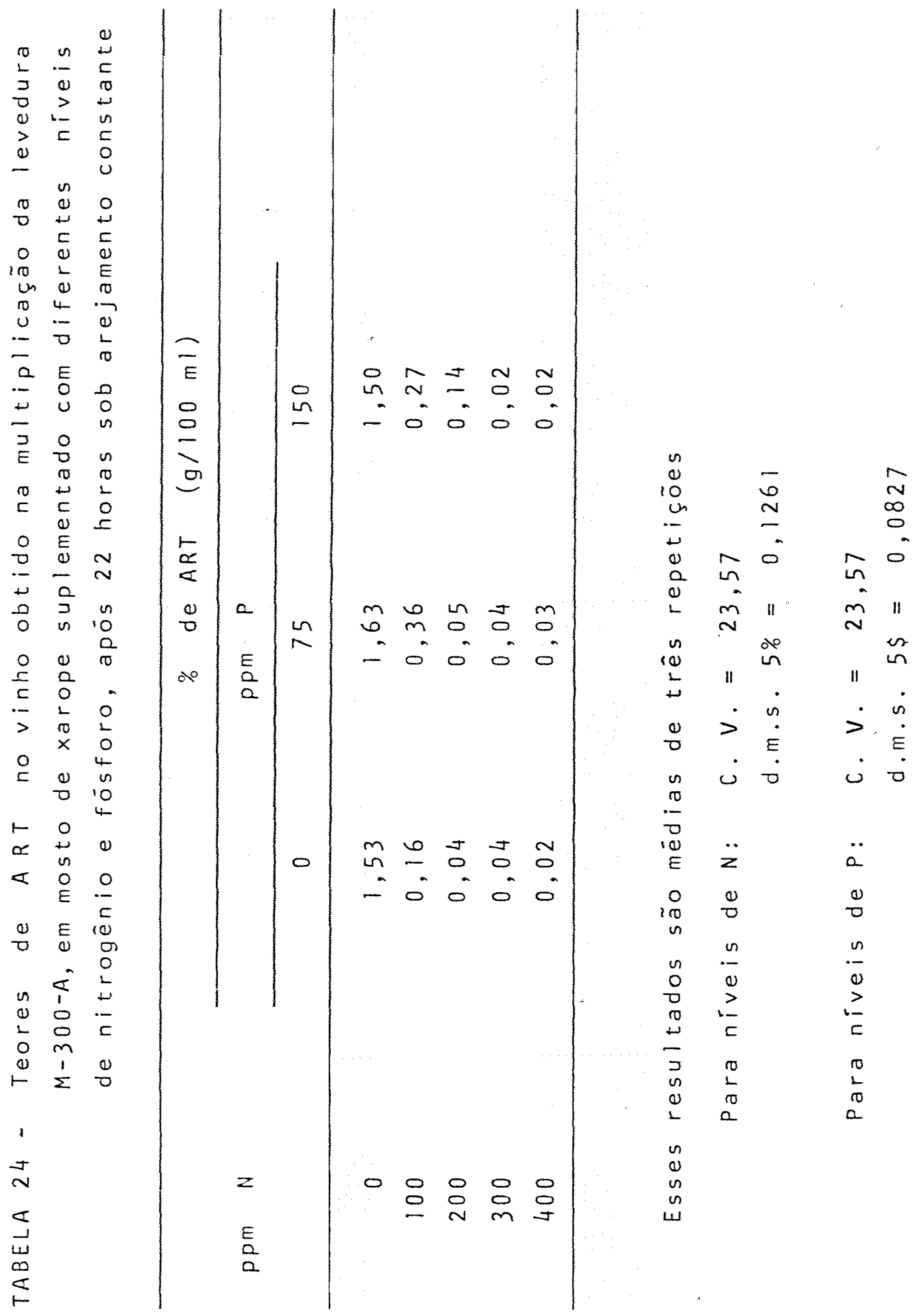




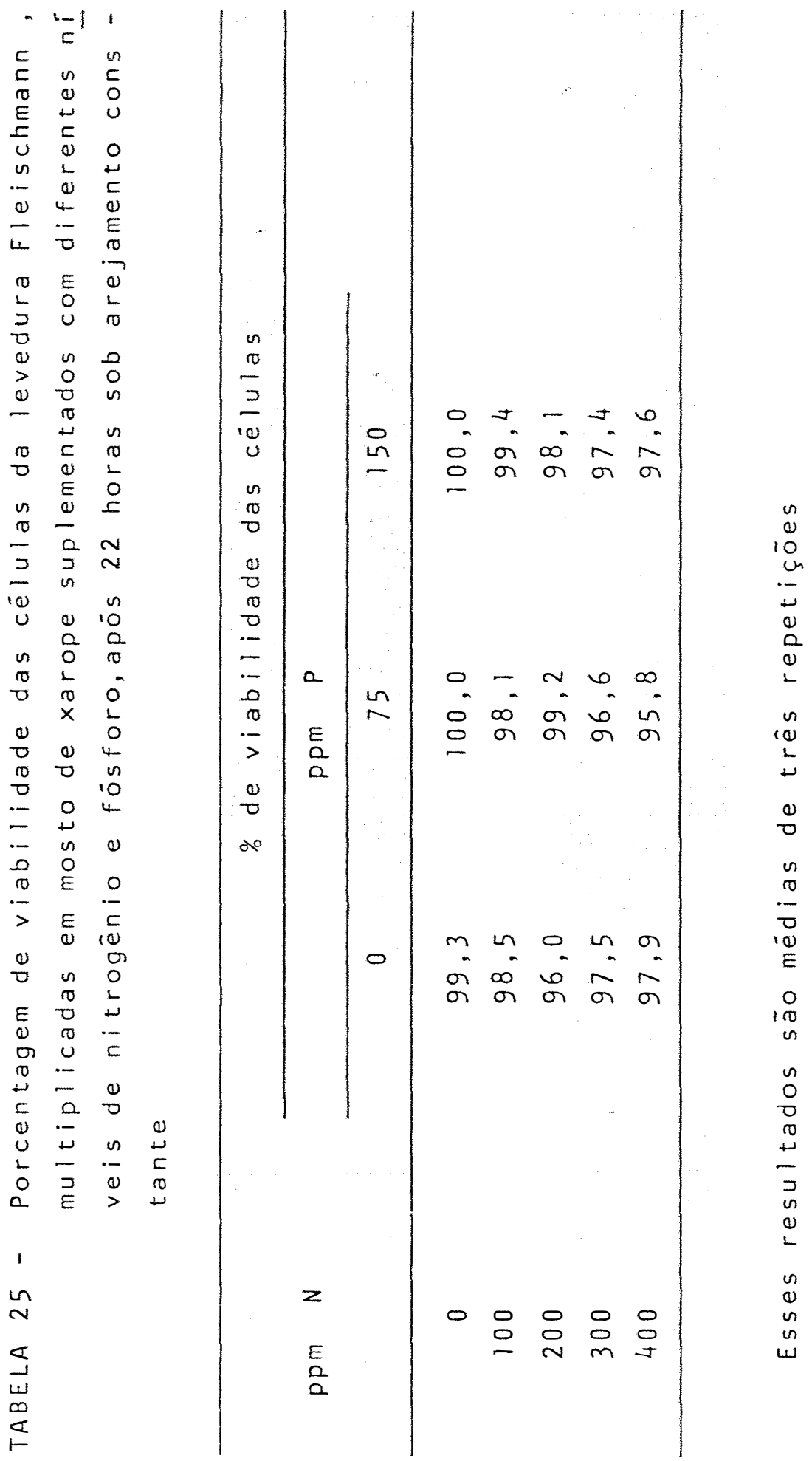




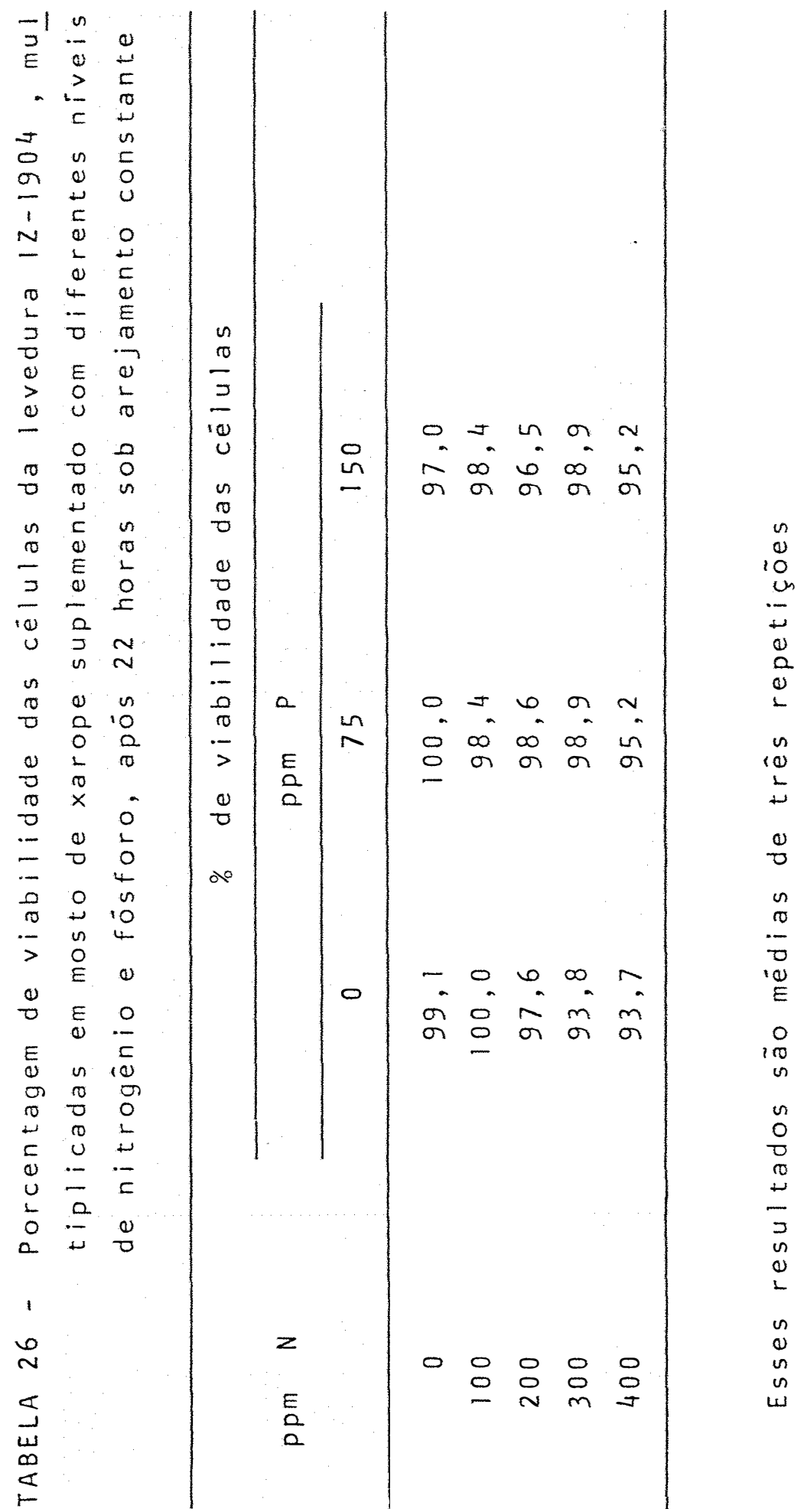




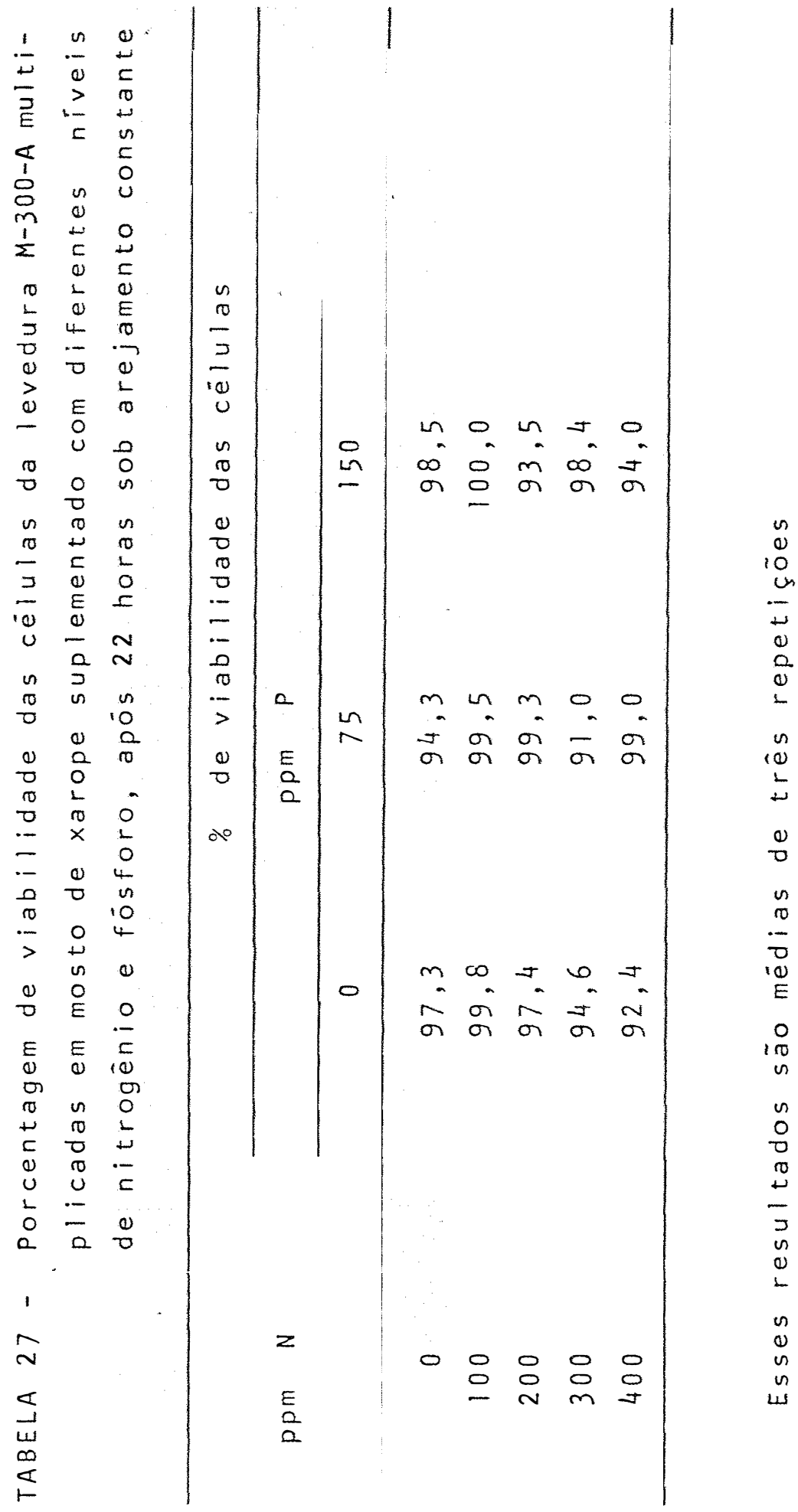




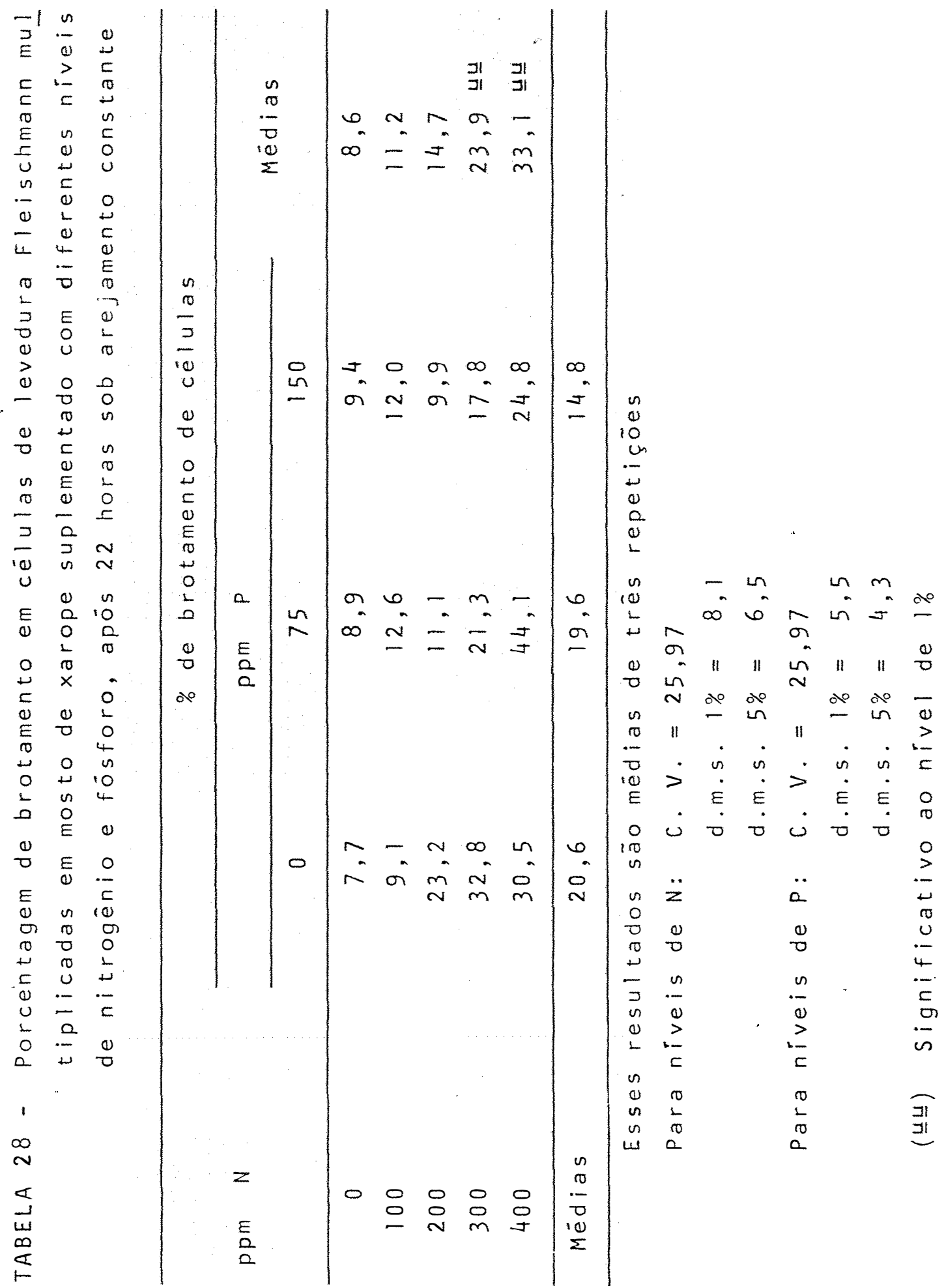


117.

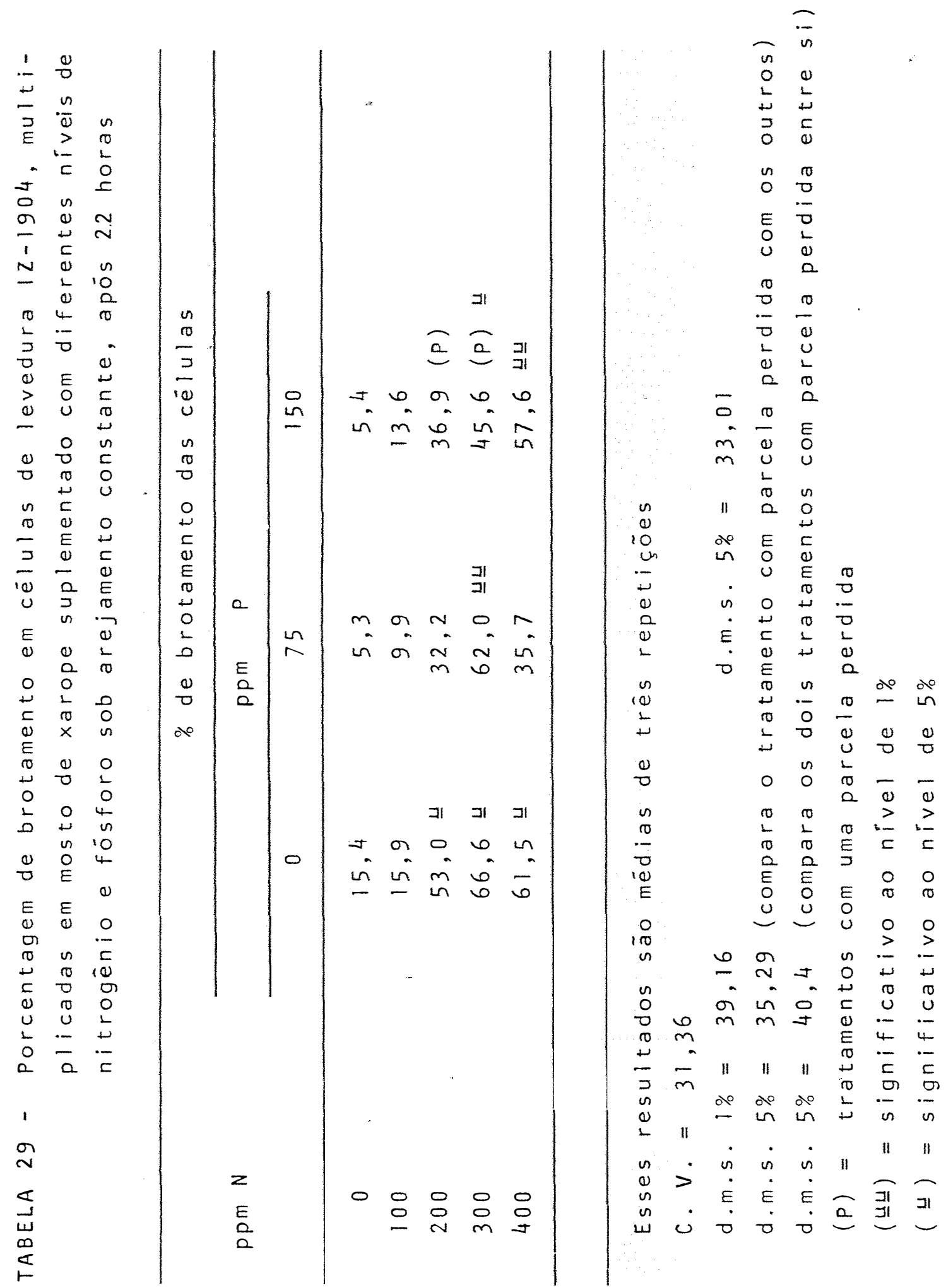


118.

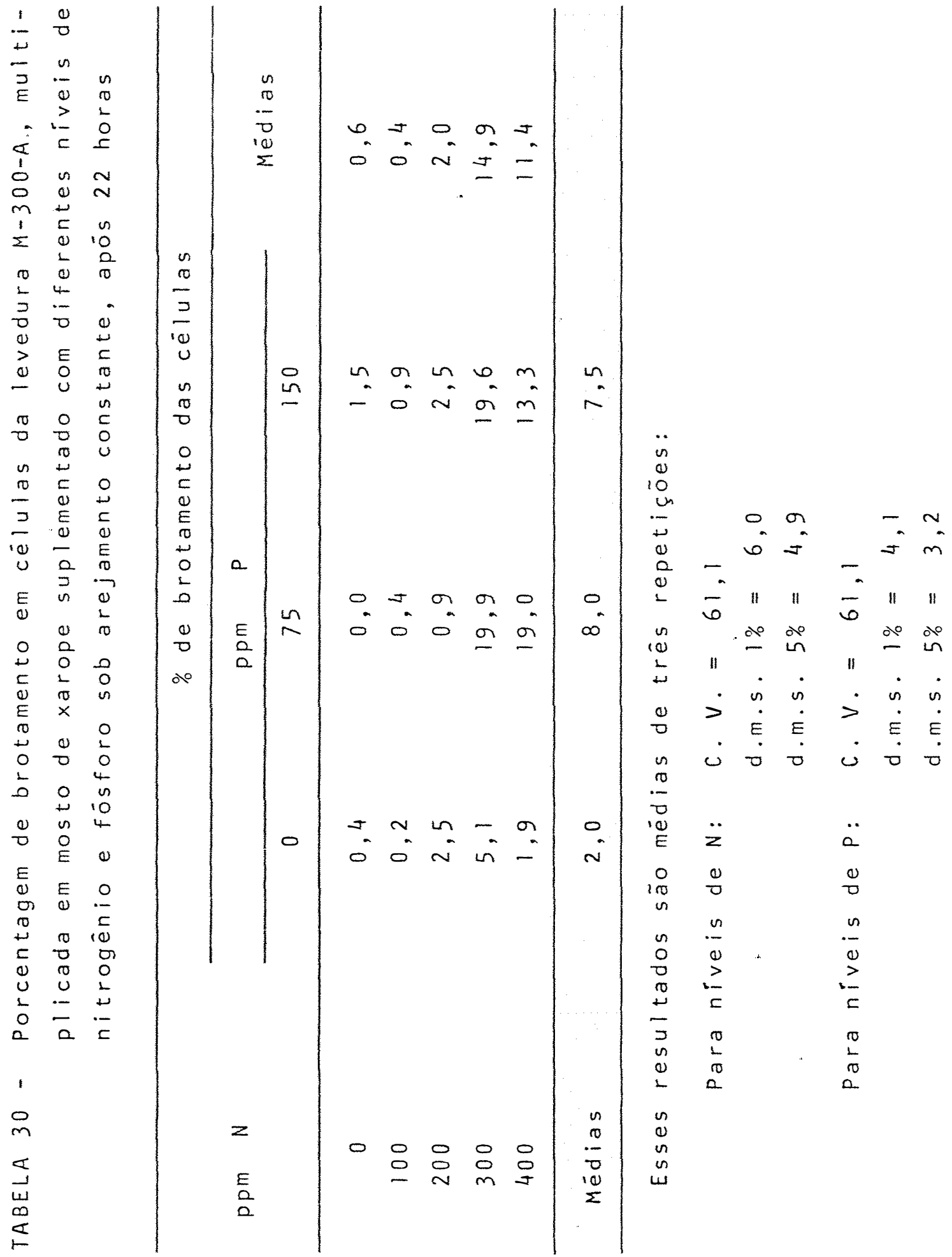


TABELA $31^{\prime}$ - Teores de minerais da levedura fleischmann multiplicada em mosto de xarope suplementado com di ferentes niveis de nitrogénio e fósforo

\begin{tabular}{|c|c|c|c|c|c|c|c|c|}
\hline \multicolumn{3}{|c|}{ Tratamento } & $\begin{array}{l}N \\
\%\end{array}$ & $\begin{array}{l}P \\
\%\end{array}$ & $\begin{array}{l}K \\
\%\end{array}$ & $\begin{array}{l}\mathrm{Mg} \\
\%\end{array}$ & $\begin{array}{r}\text { Mn } \\
\text { ppm }\end{array}$ & $\begin{array}{r}2 n \\
p p m\end{array}$ \\
\hline 0 & $x$ & 0 & 3,6 & 0,5 & 1,7 & 0,13 & 17 & 670 \\
\hline 100 & $x$ & 0 & 3,7 & 2,0 & 1,9 & 0,20 & 17 & 666 \\
\hline 200 & $x$ & 0 & 4,1 & 2,1 & 2,7 & 0,26 & 28 & 590 \\
\hline 300 & $x$ & 0 & 5,5 & 1,9 & 2,2 & 0,30 & 26 & 434 \\
\hline 400 & $x$ & 0 & 6,9 & 2,2 & 2,1 & 0,30 & 26 & 448 \\
\hline 0 & $x$ & 75 & 3,2 & 1,7 & 2,6 & 0,29 & 25 & 710 \\
\hline 100 & $x$ & 75 & 2,2 & 2,1 & 2,8 & 0,28 & 25 & 650 \\
\hline 200 & $x$ & 75 & 3,9 & 2,1 & 2,7 & 0,29 & 25 & 597 \\
\hline 300 & $x$ & 75 & 4,9 & 2,0 & 2,6 & 0,30 & 33 & 489 \\
\hline 400 & $x$ & 75 & 6,2 & 2,3 & 2,4 & 0,34 & 33 & 478 \\
\hline 0 & $x$ & 150 & 3,3 & 2,0 & 2,5 & 0,26 & 23 & 563 \\
\hline 100 & $x$ & 150 & 3,4 & 2,0 & 2,6 & 0,28 & 22 & 589 \\
\hline 200 & $x$ & 150 & 4,1 & 2,1 & 2,6 & 0,31 & 24 & 602 \\
\hline 300 & $x$ & 150 & 6,9 & 2,1 & 2,7 & 0,29 & 28 & 474 \\
\hline 400 & $x$ & 150 & 5,8 & 2,2 & 2,8 & 0,38 & 29 & 496 \\
\hline
\end{tabular}


TABELA 32 - Teores de minerais da levedura $12-1904$ multipli cada em mosto de xarope suplementado com diferentes niveis de nitrogénio e fösforo

\begin{tabular}{|c|c|c|c|c|c|c|c|c|}
\hline \multicolumn{3}{|c|}{ Tratamento } & $\begin{array}{l}N \\
\%\end{array}$ & $\begin{array}{l}P \\
\%\end{array}$ & $\begin{array}{l}K \\
\%\end{array}$ & $\begin{array}{l}\mathrm{Mg} \\
\%\end{array}$ & $\begin{array}{r}M n \\
\mathrm{ppm}\end{array}$ & $\begin{array}{r}\mathrm{Zn} \\
\mathrm{ppm}\end{array}$ \\
\hline 0 & $x$ & 0 & 5,5 & 0,6 & 2,2 & 0,21 & 44 & 1.137 \\
\hline 100 & $x$ & 0 & 5,7 & 2,1 & 2,7 & 0,61 & 50 & 1.575 \\
\hline 200 & $x$ & 0 & 6,1 & 2,3 & 1,9 & 0,49 & 63 & 1.437 \\
\hline 300 & $x$ & 0 & 7,0 & 2,2 & 1,9 & 0,46 & 90 & 1.050 \\
\hline 400 & $x$ & 0 & 8,3 & 2,3 & 1,8 & 0,46 & 138 & 912 \\
\hline 0 & $x$ & 75 & 5,3 & 1,9 & 2,8 & 0,49 & 40 & 1.612 \\
\hline 100 & $x$ & 75 & 5,3 & 2,2 & 3,0 & 0,46 & 53 & 1.637 \\
\hline 200 & $x$ & 75 & 6,0 & 2,0 & 2,1 & 0,39 & 64 & 1.037 \\
\hline 300 & $x$ & 75 & 8,1 & 2,5 & 2,3 & 0,48 & 106 & 1.100 \\
\hline 400 & $x$ & 75 & 8,5 & 2,4 & 2,0 & 0,51 & 119 & 1.050 \\
\hline 0 & $x$ & 150 & 5,2 & 2,1 & 3,0 & 0,44 & 35 & 1.575 \\
\hline 100 & $x$ & 150 & 5,7 & 2,3 & 3,0 & 0,44 & 50 & 1.600 \\
\hline 200 & $x$ & 150 & 6,0 & 2,3 & 2,7 & 0,41 & 64 & 1.312 \\
\hline 300 & $x$ & 150 & 7,0 & 2,3 & 2,5 & 0,39 & 79 & 1.112 \\
\hline 400 & $x$ & 150 & 8,6 & 2,5 & 2,3 & 0,44 & 131 & 1.037 \\
\hline
\end{tabular}


TABELA 33 - Teores de minerais da levedura M-300-A, multiplicada em mosto de xarope suplementado com diferentes niveis de nitrogènio e fósforo

\begin{tabular}{|c|c|c|c|c|c|c|c|c|}
\hline \multicolumn{3}{|c|}{ Tratamento } & $\begin{array}{l}N \\
\%\end{array}$ & $\begin{array}{l}P \\
\%\end{array}$ & $\begin{array}{l}K \\
\%\end{array}$ & $\begin{array}{l}\mathrm{Mg} \\
\%\end{array}$ & $\begin{array}{r}M n \\
\text { ppm }\end{array}$ & $\begin{array}{r}\mathrm{Zn} \\
\mathrm{ppm}\end{array}$ \\
\hline 0 & $x$ & 0 & 4,2 & 1,5 & 2,1 & 0,27 & 26 & 730 \\
\hline 100 & $x$ & 0 & 4,5 & 2,8 & 2,4 & 0,35 & 28 & 798 \\
\hline 200 & $x$ & 0 & 5,7 & 2,8 & 2,8 & 0,37 & 37 & 725 \\
\hline 300 & $x$ & 0 & 7,2 & 2,7 & 2,3 & 0,39 & 35 & 751 \\
\hline 400 & $x$ & 0 & 7,6 & 3,0 & 2,7 & 0,39 & 35 & 730 \\
\hline 0 & $x$ & 75 & 4,5 & 2,7 & 2,7 & 0,38 & 33 & 746 \\
\hline 100 & $x$ & 75 & 4,8 & 2,5 & 2,4 & 0,40 & 32 & 805 \\
\hline 200 & $x$ & 75 & 5,2 & 2,9 & 2,7 & 0,41 & 29 & 790 \\
\hline 300 & $x$ & 75 & 6,3 & 2,5 & 2,2 & 0,35 & 31 & 727 \\
\hline 400 & $x$ & 75 & 6,8 & 2,8 & 2,0 & 0,36 & 37 & 710 \\
\hline 0 & $x$ & 150 & 4,5 & 2,8 & 2,8 & 0,39 & 27 & 587 \\
\hline 100 & $x$ & 150 & 4,9 & 2,7 & 2,1 & 0,32 & 23 & 686 \\
\hline 200 & $x$ & 150 & 5,7 & 2,8 & 2,5 & 0,38 & 27 & 735 \\
\hline 300 & $x$ & 150 & 6,5 & 2,7 & 2,7 & 0,34 & 29 & 686 \\
\hline 400 & $x$ & 150 & 6,8 & 2,9 & 2,5 & 0,34 & 47 & 698 \\
\hline
\end{tabular}


TABELA 34 - Relação entre matéria seca e porcentagem de brotamento em levedura Fleischmann

\begin{tabular}{lccc}
\hline Matéria seca $(\mathrm{mg})^{1} \%$ de brotamento & Matéria seca $(\mathrm{mg})^{\prime} \%$ de brotamento \\
\hline 294 & 5,3 & 992 & 28,1 \\
342 & 13,1 & 1.002 & 10,1 \\
480 & 9,1 & 1.007 & 14,7 \\
486 & 2,8 & 1.035 & 25,6 \\
514 & 12,0 & 1.058 & 20,5 \\
518 & 4,7 & 1.060 & 42,8 \\
526 & 9,3 & 1.067 & 18,2 \\
566 & 9,0 & 1.069 & 30,2 \\
567 & 9,7 & 1.071 & 26,4 \\
591 & 8,7 & 1.074 & 34,9 \\
595 & 29,6 & 1.077 & 29,9 \\
595 & 15,4 & 1.085 & 25,8 \\
602 & 8,0 & 1.085 & 32,8 \\
617 & 4,3 & 1.096 & 35,7 \\
687 & 17,3 & 1.101 & 50,0 \\
721 & 49,6 & 1.111 & 33,9 \\
790 & 46,3 & 1.125 & 39,7 \\
804 & 47,6 & 1.127 & 23,9 \\
835 & 10,0 & 1.132 & 20,1 \\
882 & 5,7 & 1.150 & 12,1 \\
883 & 48,4 & 1.151 & 15,5 \\
884 & 17,0 & 1.160 & 14,0 \\
934 & 12,4 & 1.184 & 30,1 \\
945 & 8,4 & 1.194 & 10,1 \\
958 & 11,5 & 1.202 & 13,3 \\
967 & 25,1 & 1.219 & 7,9 \\
968 & 35,8 & 1.225 & 7,7 \\
978 & 14,9 & 1.235 & 20,6 \\
983 & 11,2 & 1.244 & \\
989 & 27,5 & & \\
\hline
\end{tabular}


TABELA 35 - Relação entre matéria seca e porcentagem de brotamento em levedura 12-1904

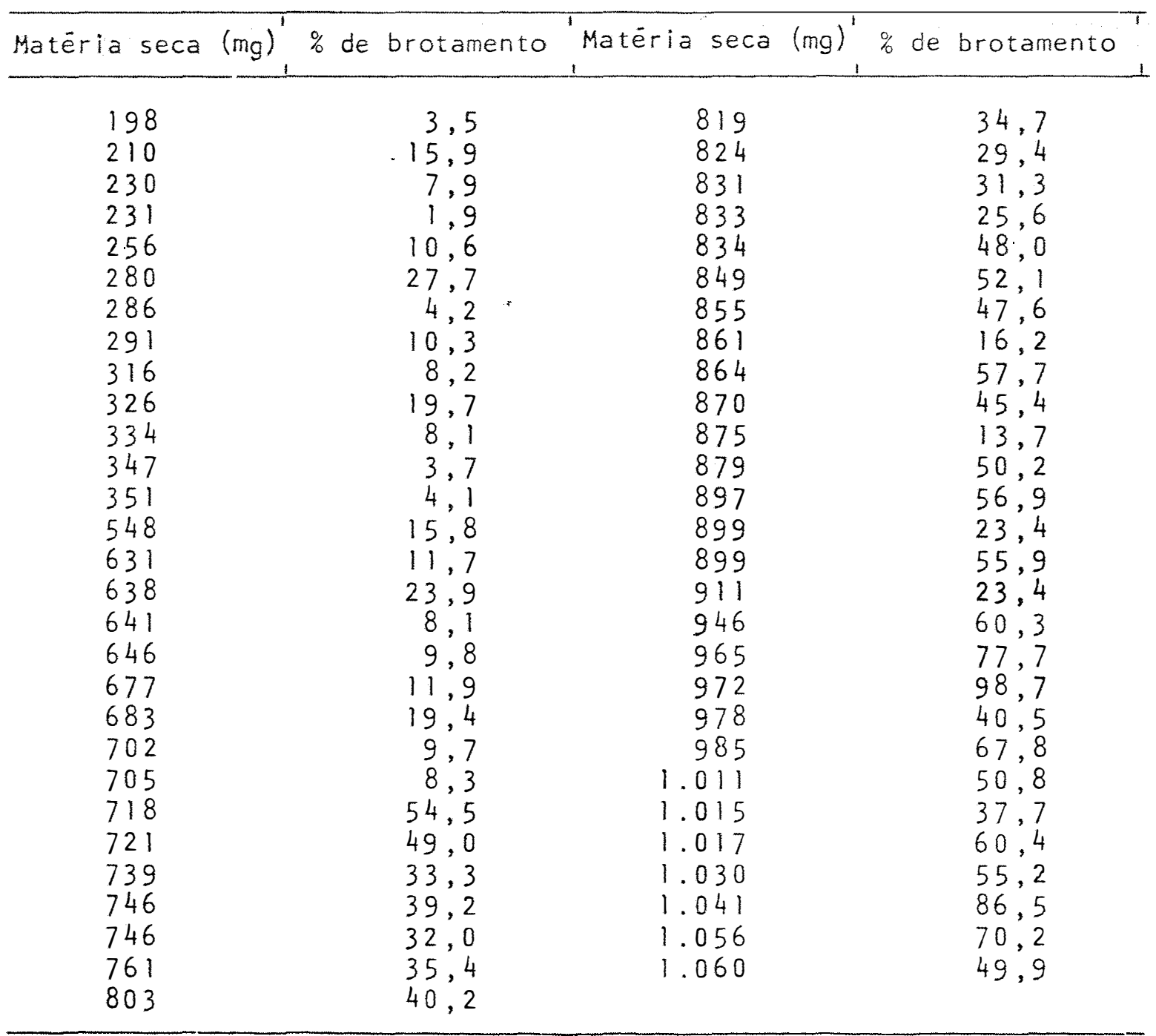


TABELA 36 - Relação entre matēria seca e porcentagem de brotamento em levedura M-300-A

\begin{tabular}{lccc}
\hline Matéria seca $(\mathrm{mg})^{\prime} \%$ de brotamento Matéria seca $(\mathrm{mg})^{\prime} \%$ de brotamento \\
\hline 248 & 0,5 & 711 & 7,5 \\
264 & 0,8 & 715 & 45,3 \\
267 & 2,5 & 721 & 11,0 \\
270 & 1,4 & 726 & 40,4 \\
276 & 0,0 & 728 & 53,2 \\
277 & 0,0 & 728 & 0,0 \\
282 & 0,8 & 743 & 2,6 \\
288 & 12,8 & 744 & 2,9 \\
296 & 0,0 & 757 & 0,3 \\
314 & 18,7 & 767 & 47,3 \\
408 & 15,0 & 772 & 0,0 \\
439 & 11,6 & 783 & 0,9 \\
352 & 0,0 & 789 & 0,3 \\
490 & 0,0 & 795 & 3,6 \\
519 & 1,8 & 810 & 0,0 \\
523 & 0,5 & 811 & 2,9 \\
523 & 38,0 & 814 & 43,0 \\
540 & 0,0 & 820 & 0,0 \\
566 & 0,0 & 829 & 15,0 \\
619 & 0,6 & 833 & 27,8 \\
622 & 0,7 & 855 & 13,4 \\
629 & 15,8 & 857 & 13,4 \\
648 & 0,0 & 857 & 23,9 \\
665 & 0,0 & 866 & 21,4 \\
670 & 32,7 & 875 & 21,0 \\
674 & 39,4 & 912 & 19,6 \\
706 & 6,9 & 930 & 15,7 \\
706 & 36,8 & 932 & 10,2 \\
& & 946 & 5,7 \\
& & 963 & \\
\hline
\end{tabular}


TABELA 37 - População bacteriana após a multiplicação das le veduras Fleischmann, 1Z-1904 e M-300-A, após 22 horas sob arejamento constante:

\section{I? Experimento}

19) Efeito da suplementação dos värios elementos em mosto de xarope e melaço na multiplicação das leveduras fleischmann, $1 Z-1904$ e $M-300-A$

\begin{tabular}{l|cccccc}
\hline & \multicolumn{3}{c}{$\times 10^{6}$ bactérias por ml de vinho bruto } \\
\hline & Fleischmann & $12-1904$ & $M-300-A$ \\
\hline Xarope & 10 & 29 & 10 & 29 & 10 & 29 \\
Melaço & 10,6 & 6,6 & 5,0 & 5,1 & 5,0 & 7,0 \\
\hline
\end{tabular}

2: Experimento

Efeito da suplementação dos elementos nitrogēnio e fósfó ro em diferentes níveis em mosto de xarope, na multiplicação das leveduras Fleischmann, 1Z-1904 e M-300-A

\begin{tabular}{|c|c|c|c|c|c|}
\hline & & $\times 10^{6}$ & bactérias & por $m l$ de vinho & bruto \\
\hline & & $\mathrm{Fle}$ & ischmann & $1 z-1904$ & $M-300-A$ \\
\hline 1 & repetição & & 7,0 & 1,5 & 0,2 \\
\hline $2 \stackrel{a}{.}$ & repetição & & 5,0 & 2,0 & 0,2 \\
\hline 3. & repetição & & 8,0 & 0,9 & 0,5 \\
\hline
\end{tabular}

